DANIEL GORNI

MODELAGEM PARA OPERAÇÃO DE BUS RAPID TRANSIT

São Paulo

2010 
DANIEL GORNI

\section{MODELAGEM PARA OPERAÇÃO DE BUS RAPID TRANSIT}

Dissertação apresentada à Escola Politécnica da Universidade de São Paulo para obtenção do título de Mestre em Engenharia

São Paulo 
DANIEL GORNI

\section{MODELAGEM PARA OPERAÇÃO DE BUS RAPID TRANSIT}

Dissertação apresentada à Escola Politécnica da Universidade de São Paulo para obtenção do título de Mestre em Engenharia Área de Concentração: Engenharia de Transportes - Informações Espaciais

Orientador: Prof. Dr. Marcos Rodrigues

São Paulo

2010 
Este exemplar foi revisado e alterado em relação à versão original, sob responsabilidade única do autor e com a anuência de seu orientador.

São Paulo, de dezembro de 2010.

Assinatura do autor

Assinatura do orientador

FICHA CATALOGRÁFICA

Gorni, Daniel

Modelagem para operação de bus rapid transit / D. Gorni -ed.rev. -- São Paulo, 2010. $113 p$.

Dissertação (Mestrado) - Escola Politécnica da Universidade de São Paulo. Departamento de Engenharia de Transportes.

1. Ônibus 2. Veículos (Monitoramento) 3. Sistemas de informação geográfica I. Universidade de São Paulo. Escola Politécnica. Departamento de Engenharia de Transportes II. t. 


\section{AGRADECIMENTOS}

Ao meu orientador Marcos Rodrigues, não só por acreditar no meu trabalho, mas por participar efetivamente nas reflexões e decisões que foram necessárias para a conclusão desta dissertação. Ainda com relação ao orientador, pelos horizontes abertos nas disciplinas que realizei o tendo como professor. No meu caso em particular, o que aprendi em relação a Sistemas de Informação Geográfica influenciou muito tanto minha vida pessoal quanto profissional.

Aos professores da POLI com quem tive o prazer de obter conhecimento, em especial ao Professor José Alberto Quintanilha, que sempre com sua calma e visão pode me ajudar e guiar principalmente nos momentos mais turbulentos pelos quais passei.

Aos alunos e funcionários que também contribuíram, uns mais, outros menos, mas no que puderam.

Agradeço aos meus familiares, pela compreensão e educação provida. Sem eles, este trabalho não teria sido possível. E claro, a Deus. 
"De longe, a maior e mais admirável forma de sabedoria é aquela necessária para planejar e embelezar as cidades e comunidades humanas."

(Sócrates) 


\section{RESUMO}

Este trabalho é um modelo para controle de operação de frota de ônibus público urbano de baixa demanda, que objetiva o monitoramento (e intervenção, quando necessário), de forma que os ônibus monitorados cumpram a programação prédeterminada pela grade-horária, evitando assim situações indesejáveis como atrasos ou congestionamentos nas estações de embarque e desembarque. A gestão do controle da movimentação dos ônibus se baseia em intervenções a serem realizadas na frota, considerando-se o sistema Bus Rapid Transit, que possui como grande diferencial as faixas segregadas para circulação dos ônibus. O objetivo é propor intervenções na frota (ações enviadas diretamente ao motorista como, por exemplo, diminuir a velocidade), e analisar os resultados, de forma a contribuir para diminuir dois grandes problemas em transporte público urbano: (1) o não cumprimento dos horários e (2) congestionamentos nas estações. Esses dois problemas geram reações em cadeia que acabam também afetando a regularidade de outros ônibus que compartilhar a mesma via e estações. Instituições públicas ou privadas de ônibus urbano podem obter benefícios utilizando um bom sistema de monitoramento e controle de frota, como por exemplo: mais segurança e previsibilidade nos horários, melhor adequação entre demanda e oferta do serviço, gerenciamento da frota através dos relatórios de pontualidade e desvio, dentre outros. Além disso, a melhora da qualidade do serviço traz como conseqüência o aumento no número de usuários do transporte, devido à oferta de um sistema mais atrativo, seguro e eficiente. A metodologia apresentada neste trabalho é constituída de um modelo para monitoramento da operação da frota e detecção de inconformidades dos ônibus, baseado na grade-horária e em um algoritmo de tomada de decisão, que objetiva a correção das inconformidades identificadas. $\mathrm{Na}$ tentativa de resolver (ou diminuir) os problemas que possam surgir durante a circulação dos ônibus, algoritmos (heurísticos) de decisão são utilizados em simulações de situações adversas. Com essas simulações é possível efetuar comparação das situações "sem" e "com" as intervenções propostas pelo algoritmo de decisão. Um sistema de informação geográfica é utilizado para manipulação dos dados e apresentação dos mesmos. De forma unifilar, é possível comparar as situações com e sem intervenções. Gráficos e tabelas complementam a 
apresentação dos resultados, onde é possível identificar e perceber a vantagem no monitoramento e intervenção na frota (a fidelidade à grade-horária melhora com as situações/intervenções simuladas).

Palavras-chave: Sistema de Informação Geográfica. SIG. Monitoramento de Veículos. AVL. GPS. Bus Rapid Transit. BRT. 
ABSTRACT

This dissertation is a model for management of urban public bus fleet operation control, aimed at monitoring (and intervention when necessary) so that the buses monitored meet the pre-determined schedule by the time-grid, thus avoiding undesirable situations such as delays or congestion in the stations of embarkation and disembarkation. The proposed operational management model and the interventions to be carried out in the fleet are possible considering the Bus Rapid Transit system that has segregated roads for the movement of buses. The goal is to propose interventions in the fleet (actions will be sent directly to the driver, like change the bus velocity), and analyze the results in order to help reduce two major problems in urban public transport: (1) non compliance with the schedules and (2) congestion at stations. These two problems create chain reactions that end up affecting the regularity of other vehicles who share the same track and stations. Public or private urban bus institutes can benefit by using a good system of monitoring and control of the fleet, for example: more security and predictability in schedules, better match between demand and supply of the service, fleet management through the reports of punctuality and deviation, among others. Moreover, the improvement of service quality has as consequence the increase in the number of users of transport, due to availability of a more attractive, safe and efficient bus service. The methodology presented here consists of a model for fleet tracking (operation control) and tracing of unconformities buses based on time-grid and on an algorithm of decision-making that aims to correct non-conformities identified. In an attempt to solve (or reduce) the problems that may arise during the movement of buses, algorithms (heuristic) decision is used in simulations of adverse situations. In these simulations can be performed comparing the situations "without" and "with" the interventions proposed by the decision algorithm. A geographic information system is used for data manipulation and presentation of them. Using linear representation is possible to compare the buses situations with and without interventions. Charts and tables complement the presentation of results, where it is possible to identify and realize the advantage in monitoring and intervention in the fleet (fidelity to the time-grid improvement with the simulated situations/interventions). 
Keywords: Geographic Information System. GIS. Fleet Monitoring. AVL. GPS. Bus Rapid Transit. BRT. 


\section{LISTA DE SIGLAS E ABREVIATURAS}

SIG: Sistema de Informação Geográfica

MER: Modelo Entidade Relacionamento

GPS: Global Positioning System

BRT: Bus Rapid Transit

AVL: Localização Automática de Veículos

ITS: Sistemas de Transporte Inteligente

UML: Unified Modeling Language

OGC: Open Geospatial Consortium

IDE: Ambiente de Desenvolvimento Integrado

SQL: Structure Query Language

GNSS: Global Navigation Satellite System

EGNOS: European Geostationary Navigation Overlay Service

GLONASS: Global Navigation Satellite System

ITDP: Institute for Transport and Development Policy

VLT: Veículo Leve Sobre Trilhos

IBGE: Instituto Brasileiro de Geografia e Estatística

EPUSP: Escola Politécnica da Universidade de São Paulo

EUA: Estados Unidos da América

WMS: Web Map Services

AD_PE: Intervenção de Adiantar Ônibus Atrasado - Pular Estação

AD_OE: Intervenção de Adiantar Ônibus Atrasado - Solicitar Ônibus Extra

AT_DV: Intervenção de Atrasar Ônibus Adiantado - Diminuir Velocidade

AT_EB: Intervenção de Atrasar Ônibus Adiantado - Esperar no Buffer

AT_ED: Intervenção de Atrasar Ônibus Adiantado - Esperar na Doca

ITV: Intervalo de tempo para verificação da situação da estação

ITPO: Intervalo de tempo para próximo ônibus chegar

TG: Tempo que o ônibus deveria levar até chegar à estação

TO: Tempo que o ônibus levará até chegar à estação

DT: Diferença entre TO e TG

VTAT: Valor de tolerância de ônibus atrasado

VTAD: Valor de tolerância de ônibus adiantado 
VLOE: Valor limite para considerar intervenção ônibus extra

VDOE: Valor limite da distância do ônibus até a estação

AT: Sigla que classifica ônibus como ATRASADO

AD: Sigla que classifica ônibus como ADIANTADO

DROE: Distância Real do ônibus até a Estação

SR: Situação Real (posição do ônibus no diagrama unifilar)

SP: Situação Planejada (posição do ônibus no diagrama unifilar)

SA: Situação Alterada (posição do ônibus no diagrama unifilar)

dt: Tempo transcorrido

$\mathrm{dR}$ : Diferença de tempo entre SP e SR

$\mathrm{dA}$ : Diferença de tempo entre SP e SA

st1: Status do ônibus anterior a alguma intervenção

st2: Status do ônibus posterior a alguma intervenção 


\section{LISTA DE TABELAS E FIGURAS}

Figura 1 - Sanfonamento de diversos ônibus em estação de São Paulo ..................21

Figura 2 - Trecho de corredor de ônibus em São Paulo .........................................29

Tabela 1 - Corredores de ônibus operando em São Paulo em 2005 (fonte: SPTrans,

apud Castro, 2008)....................................................................................

Tabela 2 - Dados do BRT de três cidades diferentes ...........................................32

Figura 3 - Diagrama da descrição geral do processo ……………….....................33

Figura 4 - TransMilenio de Bogotá (foto por Karl Fjellstrom - Brasil, 2007) .............41

Figura 5 - Corredor do sistema TransMilenio em Bogotá (foto por cortesia de Volvo

Bus Corporation para o Manual de BRT - p. 11) …...........................................45



Figura 7 - Diagrama de caso de uso Acessar Sistema............................................60

Figura 8 - Diagrama de seqüência Acessar Sistema...........................................61

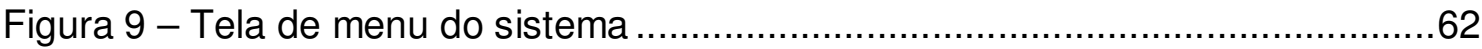

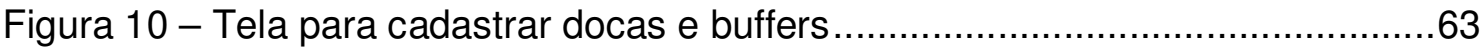

Figura 11 - Diagrama de caso de uso Cadastrar Docas e Buffers ............................63

Figura 12 - Diagrama de seqüência Cadastrar Docas e Buffers .............................64

Figura 13 - Tela para cadastrar grade de horários ..............................................64

Figura 14 - Diagrama de caso de uso Cadastrar Grades de Horários.......................65

Figura 15 - Diagrama de seqüência Cadastrar Grades de Horários..........................65

Figura 16 - Diagrama de caso de uso Armazenar Dados Posicionais do Ônibus ....66

Figura 17 - Diagrama de seqüência Armazenar Dados Posicionais do Ônibus .......66

Figura 18 - Diagrama de caso de uso Verificar Inconformidades .............................67

Figura 19 - Diagrama de caso de uso Verificar Atrasos ........................................68

Figura 20 - Diagrama de caso de uso Intervenção tipo Standby ..............................69

Figura 21- Diagrama de seqüência de Intervenção tipo Standby ............................69

Figura 22 - Diagrama de caso de uso para Intervenção Diminuir Velocidade ...........70

Figura 23 - Diagrama de seqüência de Intervenção Diminuir Velocidade .................70

Figura 24 - Diagrama de caso de uso Intervenção Esperar na Doca ou Buffer.........71

Figura 25 - Diagrama de seqüência de Intervenção Esperar na Doca ou Buffer......71

Figura 26 - Diagrama de caso de uso de Intervenção tipo Bypass ..........................72

Figura 27 - Diagrama de seqüência de Intervenção tipo Bypass ..............................72 
Figura 28 - Diagrama de caso de uso Envio de Mensagem ..................................73

Figura 29 - Diagrama de seqüência Envio de Mensagem ....................................73

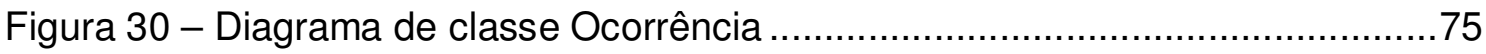

Figura 31 - Diagrama de classe Serviço .............................................................

Figura 32 - Diagrama de classe Estação.......................................................77

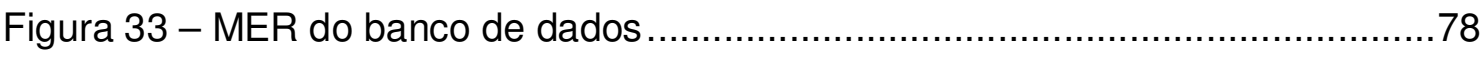

Figura 34 - Fluxograma de Identificação de Inconformidades ................................80

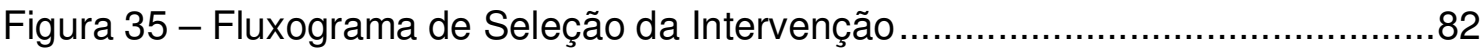

Figura 36 - São Paulo (ao centro) e outros municípios ao redor ...............................84

Figura 37 - Destaque em azul de trecho da Av. Santo Amaro e estações ................85

Figura 38 - Tela do sistema para cadastro de variáveis ....................................... 87

Figura 39 - Tela do sistema para apresentação das intervenções realizadas ...........88

Figura 40 - Diagrama unifilar do trecho em estudo com as estações do serviço......89

Figura 41 - Tela de acompanhamento e comparação das situações (SR, SP e SA)90

Tabela 3 - Análise dos 20 minutos da viagem para Saltar Estação..........................95

Figura 42 - Tela com as situações SR, SP e SA para intervenção Saltar Estação ..96 Gráfico 1 - Gráfico das situações SR, SP e SA para intervenção Saltar Estação ....97 Tabela 4 - Análise dos 20 minutos da viagem para Ônibus Extra .........................100 Figura 43 - Tela com as situações SR, SP e SA para intervenção Ônibus Extra...101 Gráfico 2 - Gráfico das situações SR, SP e SA para intervenção Ônibus Extra.....102 Tabela 5 - Análise dos 20 minutos da viagem para Ônibus Adiantado ..................103 Figura 44 - Tela com as situações SR, SP e SA para intervenção Ônibus Adiantado 104 Gráfico 3 - Gráfico das situações SR, SP e SA para intervenção Ônibus Adiantado 


\section{SUMÁRIO}

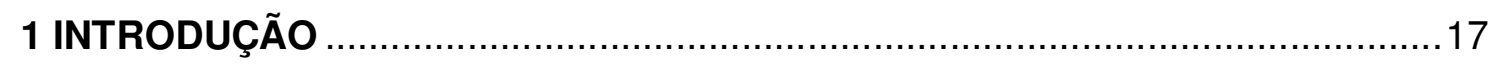

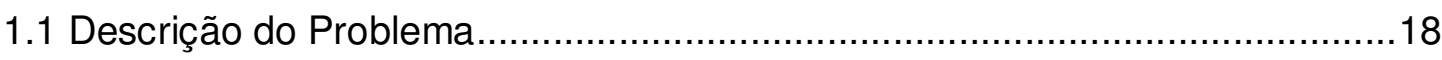

1.1.1 Sistema de Transporte Público ……………....................................19

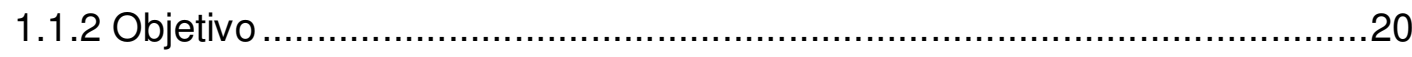

1.2 Modelos de Otimização para Controle de Frotas de Ônibus ............................23

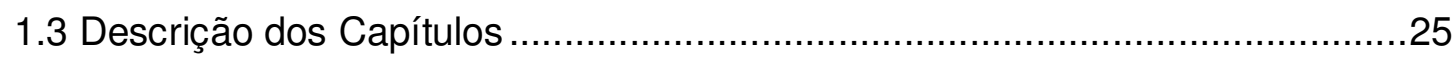

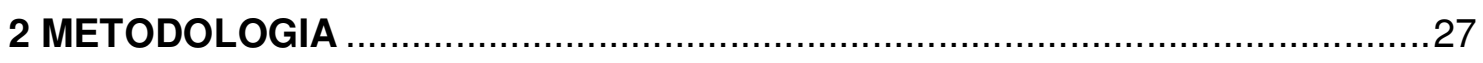

2.1 Segunda Faixa em Corredores de Ônibus.................................................28

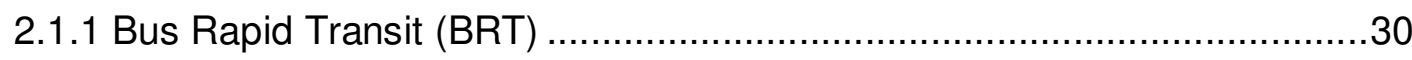

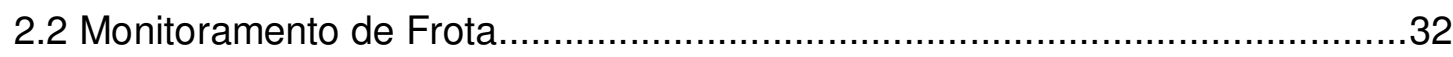

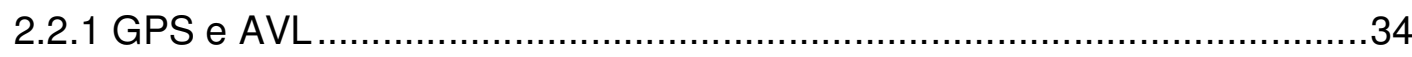

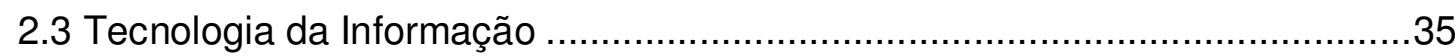

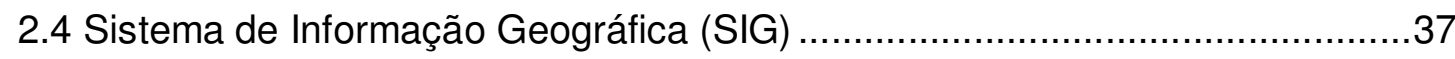

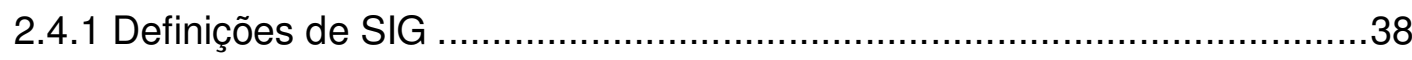

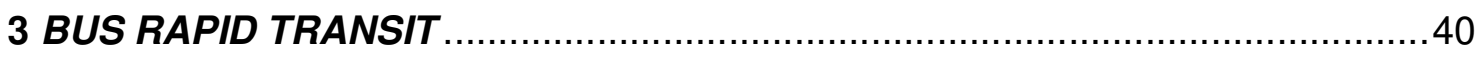

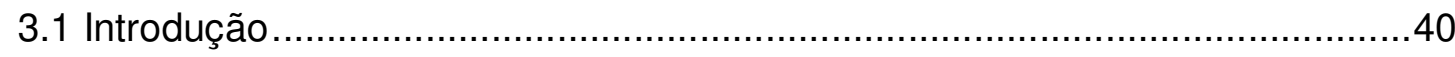



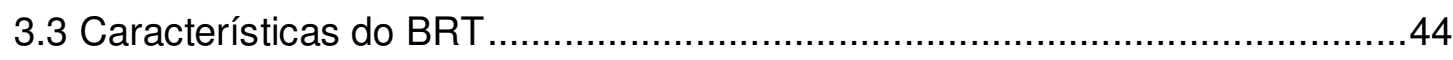

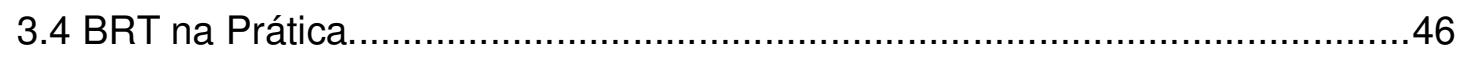

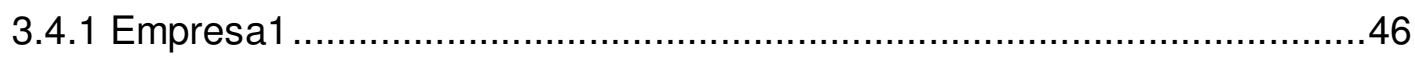

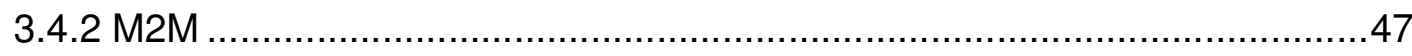

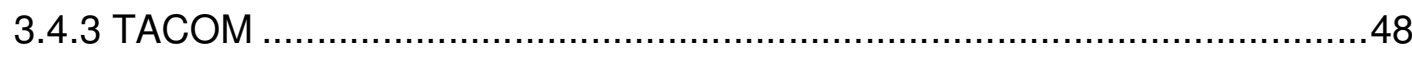

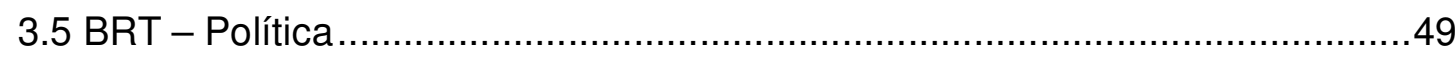








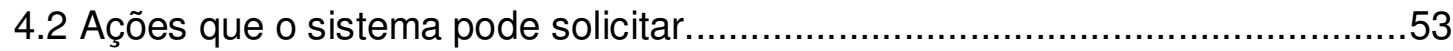

4.3 Comunicação com motoristas e passageiros …………………………….......5

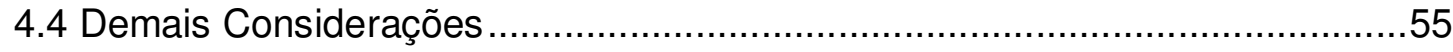

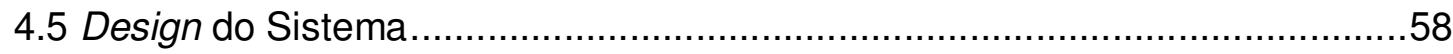

4.5.1 Telas e Diagramas de Casos de Uso e de Seqüência...............................58

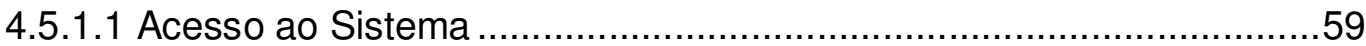

4.5.1.2 Cadastro de docas e buffers por estação .........................................62

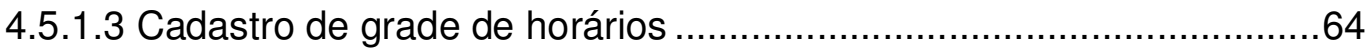

4.5.1.4 Acompanhamento das posições dos ônibus.......................................66

4.5.1.5 Verificações de Inconformidades (por estação) ..................................67

4.5.1.6 Sistema solicita uma intervenção tipo StandBy (Ônibus Extra) ..........68

4.5.1.7 Sistema solicita ao veículo que diminua a velocidade .........................70

4.5.1.8 Sistema solicita ao veículo que espere no buffer ou na doca..............71

4.5.1.9 Sistema solicita um Bypass (não parar na próxima estação) .............72

4.5.1.10 Sistema envia uma ordem específica (por voz ou texto) ..................73



4.5.2.1 Intervenções - solicitações do sistema .............................................74



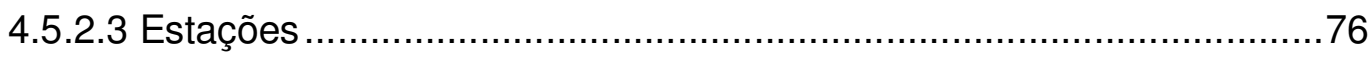

4.5.3 MER - Modelo Entidade Relacionamento do Banco de Dados .................78

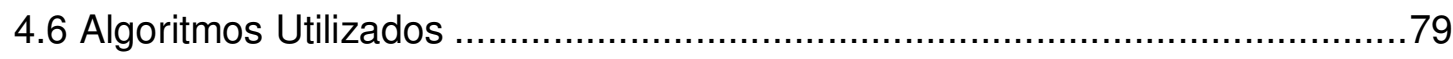

4.6.1 Identificação dos ônibus em inconformidade..........................................79

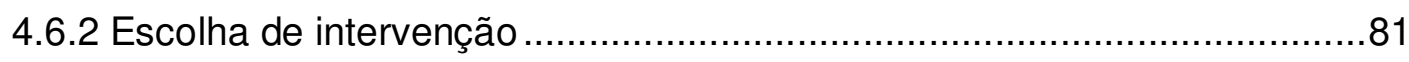

5 SIMULAÇÕES: CASO DE ESTUDO EM SÃO PAULO

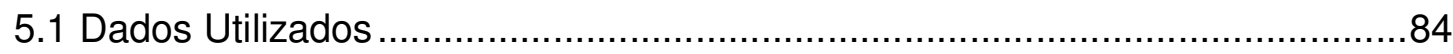




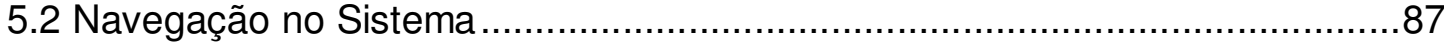

5.3 Diagramas Unifilares - visualização de comportamentos.................................8

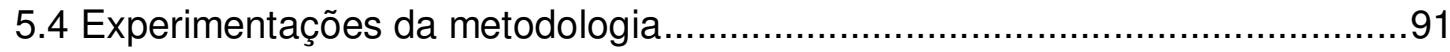

5.4.1 Experimentação de Intervenção tipo Bypass (saltar estação)....................93

5.4.2 Experimentação de Intervenção tipo Ônibus Extra ..................................98

5.4.3 Experimentação de Intervenção para Ônibus Adiantado ........................102

6 CONCLUSÕES E CONTINUIDADE DO TRABALHO …..................................106

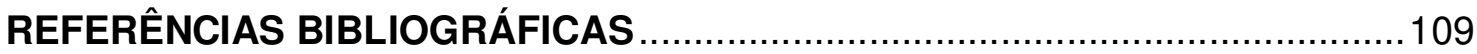




\section{INTRODUÇÃO}

Devido ao alto crescimento de diversas cidades, suas redes de transporte necessitam sofrer constantes mudanças e adaptações para que não se comprometa o sistema de transporte público. Segundo Oliveira (2000), os meios de transporte estão entre os principais fatores que afetam o processo da organização espacial das cidades, e por isso são muito importantes para o desenvolvimento da sociedade. Raia Junior (2000) diz que nas cidades modernas está cada vez mais difícil não utilizar meios motorizados para deslocamentos de pessoas ou cargas.

Quando se pensa no deslocamento em massa de pessoas em grandes cidades, o sistema de transporte público por ônibus urbano é lembrado muitas vezes pela sua baixa qualidade pelo serviço prestado. Segundo Cunha (2008), conceitos de Sistemas de Transporte Inteligente (ITS) vêm sendo citados na literatura e colocados em prática buscando estudar e melhorar a qualidade do transporte público urbano (exemplos de conceitos de ITS são: painéis informativos aos usuários sobre os horários previstos de chegada, localização automática de veículos [AVL] e sistemas eficientes de cobrança). Cada vez mais sistemas inteligentes são usados em problemas de transporte pela sua inerente relação com o espaço e tempo (monitoramento e gestão do movimento). O monitoramento enquadra-se nos casos em que apenas se obtém informação sobre estado do movimento, mas não se pode modificá-lo. Já no gerenciamento, é possível atuar modificando esse estado. Tanto o monitoramento quanto o gerenciamento podem ser auxiliados por sistemas de informação computacional, já que estes possuem características próprias como alta velocidade de tomada de decisão baseada em regras e grande capacidade de armazenamento de dados.

Este trabalho se propõe a desenvolver um modelo para gerenciamento da operação de frota de ônibus urbano em serviços de baixa demanda (gerenciamento apenas da movimentação dos veículos), utilizando sistemas de informação, que objetiva o monitoramento e intervenção na frota quando necessário. Os ônibus devem cumprir uma programação pré-determinada baseada em grades de horários. A abordagem realizada é em relação à freqüência, ou seja, a grade-horária informa em quais 
horários determinados ônibus deveriam prover serviço em determinadas estações. É possível que os ônibus sofram intervenções por parte do sistema de monitoramento caso inconformidades em relação aos horários sejam detectadas, de modo a corrigir ou ao menos diminuir a inconformidade. Essas intervenções podem ser realizadas com o intuito de reduzir custos operacionais dos veículos, evitar os congestionamentos nas estações de embarque/desembarque de passageiros e corrigir discrepâncias de tempos em relação às grades de horários.

Algumas das vantagens da gestão de frotas de ônibus são:

- Monitoramento e gerenciamento dos tempos de viagens;

- Otimização do tamanho de frota e dos tempos de viagens.

- Tornar o transporte público mais eficiente e assim, mais atrativo para os usuários, e por fim mais lucrativo;

A solução proposta neste trabalho para a gestão da operação dos ônibus urbanos, é a utilização de um sistema de monitoramento de frota baseada na localização dos ônibus com auxílio de receptores GPS (Global Positioning System), com o objetivo de intervir quando necessário, baseando-se em decisões propostas por algoritmos computacionais. Simulações de situações adversas (ônibus atrasados ou adiantados) são identificadas e intervenções realizadas com a finalidade de minimizar os efeitos dessas situações (como por exemplo, "sanfonamento" nas estações, que é o congestionamento de ônibus nas estações). Desenvolveu-se um sistema de informação para modelar o sistema de transporte, simular as situações adversas, intervir com base em algoritmos e apresentar os resultados de forma visual unifilar, em gráficos e tabelas.

\subsection{Descrição do Problema}

O sistema de transporte público é de importância indiscutível, mas em grandes cidades a qualidade do mesmo é questionável, tanto que freqüentemente é foco de estudo e pesquisa para avaliar seus problemas e buscar soluções. Devido sua 
importância e carência de qualidade, propõe-se este trabalho a explorar uma das alternativas de melhoria para o transporte público urbano por ônibus: controle da operação da frota por meio de monitoramento de frota (GPS/AVL), sistema de informação geográfica, algoritmos computacionais e simulação de comportamento. Tecnologias como internet, sistemas de informação geográfica, GPS, algoritmos de otimização, modelos de simulação, e outras, permitem uma melhora nos serviços do transporte público e representam um incentivo à sua utilização (Head et al., 1998; Mirchandani et al., 2000, apud Koehler et al., 2008).

\subsubsection{Sistema de Transporte Público}

Reis (2008) cita que um sistema de transporte coletivo eficiente e eficaz corresponde a uma importante alternativa para a melhoria da qualidade de vida nos centros urbanos por diminuir a frota de automóveis, acarretando diminuição dos congestionamentos bem como da poluição. Mas a falta de vias com prioridade para a circulação de ônibus, os quais dividem o mesmo espaço com os automóveis nos congestionamentos, e problemas relativos à organização e estrutura do sistema, reduzem a qualidade do serviço prestado e elevam o custo operacional do sistema de transporte coletivo. A cidade de São Paulo é um exemplo de como os congestionamentos podem ser prejudiciais à qualidade de vida. São Paulo se caracteriza por um crescimento desordenado, que ocorreu sem planejamento em relação ao transporte público também.

Segundo Carrara (2007), questões de ordem política, financeira e administrativa, além do tipo de desenvolvimento urbano e de transporte, são grandes obstáculos para a organização correta dos investimentos, na tentativa de resolver os problemas existentes nas cidades brasileiras. Esses problemas urbanos podem ser percebidos pelos congestionamentos crônicos do trânsito, redução de mobilidade e de acessibilidade, degradação das condições ambientais, alto consumo desnecessário de energia, etc. 
Segundo Ferraz (1997, apud Marques, 1998), o transporte público constitui um serviço indispensável nas cidades, apresentando um papel social e econômico de extrema importância, pois:

- Democratiza a mobilidade, permitindo a locomoção para aqueles que não possuem automóvel ou não podem dirigir (idosos, deficientes, etc.);

- Constitui uma alternativa de transporte em substituição ao automóvel, diminuindo os congestionamentos, a poluição e o uso abusivo de energia automotiva (principalmente as fontes não-renováveis, como o petróleo);

- Ainda como substituto do automóvel, reduz a necessidade de investimentos na construção de vias, estacionamentos, etc., permitindo que os recursos sejam destinados a setores de maior relevância social, bem como uma utilização mais racional e humana do solo urbano.

\subsubsection{Objetivo}

Segundo Wilson et al. (1992, apud Ladeira et al., 2009), o objetivo principal do controle da operação de ônibus é otimizar o desempenho do sistema possibilitando o retorno do padrão de operação pré-estabelecido quando há alguma perturbação ou interrupção do serviço. É objetivo principal deste trabalho criar um modelo para gestão da operação de ônibus, e intervenção nos mesmos (baseado em um sistema de informação), que resulte ao menos na diminuição dos dois problemas citados a seguir:

- Falta de cumprimento de horários dos ônibus: a freqüência dos ônibus nas estações é tomada como métrica maior, já que o não cumprimento da grade horária resulta em problemas acumulativos no sistema como um todo;

- Sanfonamento nos pontos de parada (Sanfonamento é o congestionamento que ocorre nas estações de embarque e desembarque devido ao elevado número de ônibus ou mesmo ao elevado tempo de permanência nas estações). 
Um dos eventos que mais incomoda usuários e operadores de ônibus, e que indiscutivelmente prejudica a operação dos mesmos, é o dito sanfonamento (Ceder, 2007, apud Ladeira et al., 2009). A Figura 1 (abaixo) apresenta um exemplo de sanfonamento ocorrido em horário de alto trânsito (09:00 AM) em uma estação (localizada embaixo de árvores no topo esquerdo da foto) na Av. Vereador José Diniz, cruzamento com a Av. Bandeirantes, em São Paulo - SP (set. 2009):

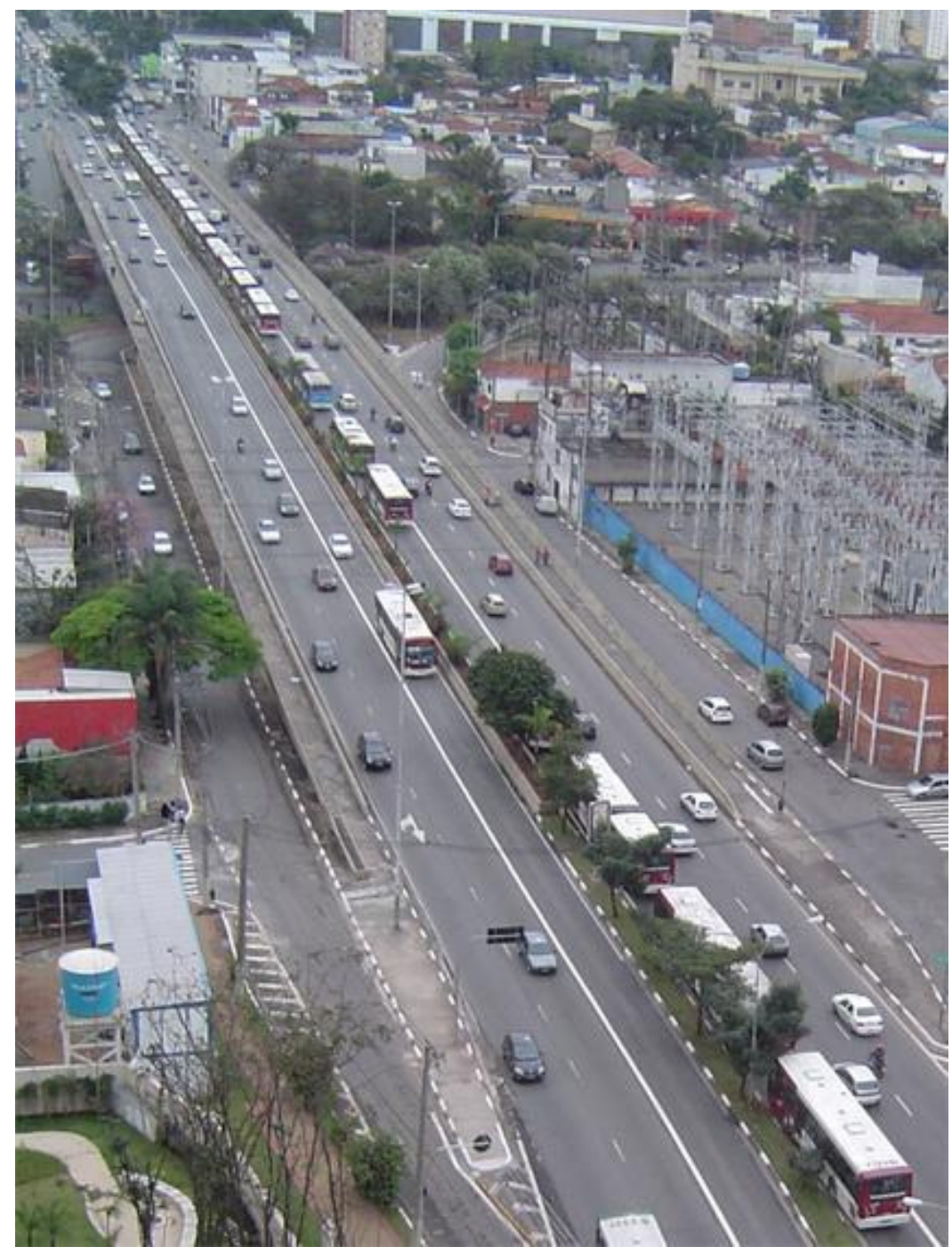

Figura 1 - Sanfonamento de diversos ônibus em estação de São Paulo

Utilizou-se um trecho de aproximadamente 7 kilômetros do corredor de ônibus Santo Amaro - Nove de Julho, na cidade de São Paulo - SP, para simulação do sistema de monitoramento e intervenção, quando necessário (quando identificada uma inconformidade), utilizando monitoramento via satélite. Um bom resultado desse tipo 
de abordagem foi logrado pela CETURB-GV (órgão criado com o fim específico de desempenhar as funções de competência do Estado, para conceder, planejar, contratar e gerenciar o Sistema de Transporte Público de Passageiro - STPP, da Região Metropolitana da Grande Vitória). Após implantar o gerenciamento de frota via satélite (fase experimental), Regis (2007) cita que, "[...] a partir dos primeiros relatórios elaborados (junho/2002) e sendo os resultados comunicados às empresas ainda que de maneira informal, verificou-se uma melhoria significativa da queda das reclamações.". E de acordo com Uliana (2006, apud Regis, 2007):

Em fevereiro de 2001 foram registradas 85 reclamações contra o Transporte Coletivo, o que, diante de uma frota de 50 veículos, representou 1,7 reclamação/veículo. Em junho/2002, após a emissão dos primeiros relatórios, ainda em fase de experiência, foram registradas 57 reclamações para uma frota de 59 ônibus, o que representa 0,96 reclamação/veículo. Ou seja, uma queda de $43 \%$ no nível de reclamações feitas pelos usuários. Esses dados, ainda que iniciais, confirmam o potencial do sistema de controle via GPS.

Em relação à acessibilidade do sistema de informação gestor da frota do ônibus, têm-se como objetivo a implementação de um sistema web, o que significa ter acesso ao sistema através de programas utilizados para navegar na internet, programas esses conhecidos como browsers. Assim, de qualquer lugar onde haja conexão à internet é possível acessar o sistema, contribuindo com a acessibilidade do mesmo.

Como objetivo geral da dissertação tem-se o desenvolvimento de pesquisa que possa oferecer resultados visíveis e, se possível, úteis para a sociedade. Gould et al. (2006) faz um questionamento interessante em relação aos serviços web de mapas (forma de acessar mapas por sistemas de informação geográfica), no que se refere aos reais benefícios em relação a utilização dos mesmos. Ele questiona sobre os benefícios econômicos e sociais dos serviços, além de refletir se os cidadãos notarão alguma diferença real com o uso dos mesmos. Este trabalho utiliza os denominados serviços web de mapas (para apresentar as posições instantâneas dos ônibus e as estações de embarque e desembarque), os quais muito auxiliaram para desenvolvimento rápido da visualização dos dados, além de seguirem padrões internacionais de manipulação/disponibilização de dados espaciais. Este ponto 
envolve interoperabilidade de dados espaciais, o que não é discutido neste trabalho, mas que possui importância no mundo de sistemas de informação geográfica.

Esta dissertação é uma pequena contribuição para melhoria dos problemas do transporte público urbano que convivemos diariamente de forma direta ou indireta.

\subsection{Modelos de Otimização para Controle de Frotas de Ônibus}

Existem diversas pesquisas direcionadas a modelos de otimização e controle de frotas de ônibus, muitas delas relacionadas com sistemas de semáforos. A seguir são apresentadas abordagens diretamente relacionadas com intersecões de vias e semáforos, bem como abordagens mais gerais utilizando modelos para controle de frota visando otimização do sistema.

Koehler (2006) apresenta um sistema de controle adaptativo para a sinalização de uma interseção (de vias), com possibilidade de prioridade para ônibus. A lógica é baseada em dois modelos de gerenciamento da partida do ônibus da estação próximo a interseção: partida imediata e partida controlada. A trajetória do ônibus da estação até a interseção é baseada num modelo de fluxo contínuo de veículos e velocidade constante ao longo da via, com possibilidade de paradas devido à filas. No modelo não é considerada a possibilidade de extensão de fase (aumento do tempo de verde na via). No caso de numa interseção isolada a extensão do verde não causaria problemas, entretanto, num sistema coordenado esta solução poderia prejudicar a progressão dos veículos, fato este que poderia ser avaliado em trabalhos futuros, conclui o autor.

Garcia et al. (2006) apresenta uma abordagem para a modelagem e projeto de coordenação semafórica utilizando a álgebra max-plus (formalismo desenvolvido para tratar problemas de controle de sistemas a eventos discretos). O objetivo é a resolução de um problema de controle de tráfego urbano através desta álgebra. Através do exemplo apresentado pelo autor, foi possível comprovar a viabilidade da abordagem, com resultado próximo ao que seria obtido com técnicas de otimização. 
O autor comenta que na época da publicação do artigo buscava-se aplicar a proposta de modelagem em vias arteriais com modelos de controle para transporte público, no caso ônibus. Mas haviam alguns impedimentos quanto a definição das restrições necessários para determinados cálculos necessários ao modelo.

Koehler et al. (2008) propõe a seguinte abordagem para o problema de priorizar veículos de transporte público em interseções semaforizadas de sistemas de corredor exclusivo com vias de tráfego normal - integrar dois níveis de operação: um nível local, referente à operação semafórica, e um nível global, que controla o headway (espaçamento entre os ônibus) dos diversos veículos de transporte público via estratégia de retenção. A integração é feita através da incorporação de restrições impostas pelo nível local, dadas pelos planos semafóricos, no cálculo dos instantes de partida ótimos dos veículos de transporte público realizados no nível global. Os resultados de simulação mostraram a factibilidade do método em termos de eficiência e rapidez de cálculo. O autor sugere para trabalhos futuros a solução do problema do controle integrado de prioridade e retenção, via técnica de programação inteira mista (com utilização de variáveis binárias), e também a inclusão das restrições associadas à capacidade limitada dos veículos de transporte público.

Delgado et al. (2009) descreve um modelo de programação matemática em tempo real para operação de ônibus em corredores de trânsito. O objetivo do modelo é minimizar os tempos totais dos passageiros desde quando chegam nas estações para embarque, até quando alcançam em seus destinos. As estratégias de controle utilizadas podem ser divididas em três categorias: (a) controle na estação - o que inclui fazer com que o ônibus espere na estação, ou mesmo não parar na mesma; (b) controle entre as estações - controle da velocidade do ônibus, e mecanismos de prioridade semafórica; e (c) outras medidas de controle - como incluir mais veículos em serviço. Ainda segundo o autor, novas tecnologias, como Global Positioning System e sistemas de localização de veículos automatizadas, tornam possível o desenvolvimento de modelos mais complexos, de forma a minimizar os tempos totais de viagens dos passageiros. Neste modelo especificamente, o problema é formulado por programação matemática determinística, que determina simultaneamente os tempos de parada nas estações ao longo do corredor, e a 
fração de passageiros deixados para trás (nas estações) após cada partida dos ônibus. O modelo proposto assume alguns pré-requisitos como por exemplo: (a) existe um fluxo homogêneo de ônibus, e (b) tempos de viagens entre as estações são determinísticos, conhecidos e fixos para o período de interesse. Após avaliação do modelo em um cenário hipotético de alta demanda, comprovou-se que a quantidade de tempo computacional gasto foi mínima, o que confirma a possibilidade de uso do mesmo em sistemas de tempo real. Além disso, a avaliação mostrou que houve redução no tempo total das viagens (Delgado et al., 2009).

No mundo real, o comportamento do sistema de transporte público pode surpreender e ocasionar situações não previamente consideradas pelos modelos, resultando em pouca eficiência de soluções propostas. Para evitar esse tipo de situação, testes exaustivos deveriam ser realizados, com base em dados reais de corredores de ônibus similares aos que são considerados nos modelos propostos. Outro ponto importante a ser considerado é o desafio de tratar, por exemplo, inconformidades operacionais da grade-horária, em conjunto com progressão semafórica.

\subsection{Descrição dos Capítulos}

O Capítulo 2 descreve a metodologia a ser aplicada para resolver o problema proposto neste trabalho (ou ao menos amenizar seus efeitos). O capítulo contém a descrição do processo como um todo, e componentes da proposta de solução (Monitoramento de Frota, Tecnologia Utilizada, SIG).

O Capítulo 3 descreve o conceito de Bus Rapid Transit (BRT). BRT tem sido aplicado com sucesso em sistemas de transporte público urbano por ônibus em diversas cidades ao redor do mundo. Uma das suas principais características é a utilização dos corredores segregados para trânsito dos ônibus.

O Capítulo 4 descreve a especificação da solução citando os dois comportamentos de inconformidade dos ônibus que podem ocorrer (Atrasado e Adiantado), como o 
sistema identifica as inconformidades, e quais ações (intervenções) o sistema pode executar para tentar resolver o problema. No capítulo também se apresenta o design do sistema (com telas do sistema, diagramas UML de casos de uso e de classe, bem como o Modelo Entidade-Relacionamento do banco de dados utilizado). Ao final do capítulo os algoritmos de identificação de inconformidade e tomadas de decisão de intervenção (e seus fluxogramas) são apresentados.

O Capítulo 5 apresenta a aplicação da metodologia em simulações para um caso de estudo em parte da avenida Santo Amaro (São Paulo - SP). Os resultados são apresentados em formato de gráficos, tabelas e mapas unifilares.

O Capítulo 6 apresenta as conclusões deste trabalho e possíveis trabalhos futuros. 


\section{METODOLOGIA}

A metodologia deste trabalho baseia-se em primeiramente implementar o modelo do sistema de transporte objetivando detectar inconformidades dos ônibus em relação às grades de horário. A seguir, algoritmos de tomada de decisão sugerem as intervenções na frota (durante simulações de comportamento da mesma enfrentando adversidades nas condições de trânsito). Então, diagramas unifilares, tabelas e gráficos apresentam os resultados das intervenções realizadas. Em poucas palavras, a metodologia proposta é a seguinte:

1. Implementar um sistema de controle de operação de transporte coletivo por ônibus (cadastro de estações, ônibus, grades de horários de serviços, etc.);

2. Desenvolver um SIG que apresente as posições instantâneas dos ônibus (conceito de monitoramento de frota utilizando receptores GPS);

3. Identificar inconformidades comparando os dados das localizações dos ônibus e das grades de horários dos serviços;

4. No caso de inconformidades, selecionar com base em algoritmos algum tipo de intervenção (são propostos 5 tipos de intervenções);

5. Apresentar os resultados em tabelas, gráficos e diagramas unifilares comparando o comportamento dos ônibus com e sem as intervenções sugeridas pelo sistema.

A metodologia aqui proposta para detectar as inconformidades faz uso de monitoramento de frotas de veículos (conhecer as posições instantâneas dos ônibus). Com o foco na estação de parada do ônibus (ou seja, cada estação monitora os ônibus que deveriam atendê-la dentro de um intervalo de tempo prédeterminado), e com base em dados como velocidade média no trecho em que se encontra o veículo e a distância até uma determinada estação, é possível então inferir quanto tempo o ônibus levará para chegar à estação. Se este tempo não for aceitável, o algoritmo será executado para intervir, com a finalidade de corrigir, ou ao menos diminuir, a defasagem de tempo identificada. Esta ação de intervir divide-se 
em dois tipos básicos: intervenção para quando o ônibus está atrasado, e para quando ele está adiantado. As intervenções propostas neste trabalho são:

- Solicitar ao motorista que não pare em determinada estação.

- Solicitar alocação de mais veículos em casos de atrasos significativos.

- Solicitar ao motorista que diminua a velocidade.

- Solicitar ao motorista que estacione no local de espera (buffer) para não acumular veículos nos pontos de parada.

- Solicitar ao motorista que permaneça por maior tempo estacionado na doca, desde que não haja outros ônibus necessitando utilizar a doca.

Segundo Abkowitz (1978, apud Ladeira et al., 2009), as principais estratégias de controle de frota de ônibus em tempo real podem ser: "segurar" o ônibus na estação ou terminal; inserção de um veículo reserva; mudança da velocidade; ultrapassar; aguardar; não parar em determinada estação; veículo expresso; um veículo realiza embarque/desembarque e o outro não, quando identificado um sanfonamento.

Cada uma das 5 intervenções propostas neste trabalho (acima) se enquadram em alguma das estratégias de controle de frota de ônibus em tempo real citadas por Abkowitz (1978, apud Ladeira et al., 2009).

\subsection{Segunda Faixa em Corredores de Ônibus}

A primeira intervenção proposta (Solicitar ao motorista que não pare em determinada estação) é importante devido à estrutura de corredores de ônibus, na qual se aplica esse trabalho. A Figura 2 apresenta um trecho do corredor de ônibus (conceito onde as vias são preferenciais para trânsito de ônibus) na Av. Vereador José Diniz, altura do número 3.800, em São Paulo - SP (jun. 2010), onde é possível observar uma segunda faixa de tráfego na região da estação, o que torna possível ultrapassagem. Assim, esta segunda faixa pode ser utilizada por ônibus que sofreram intervenção de não parar na estação. 


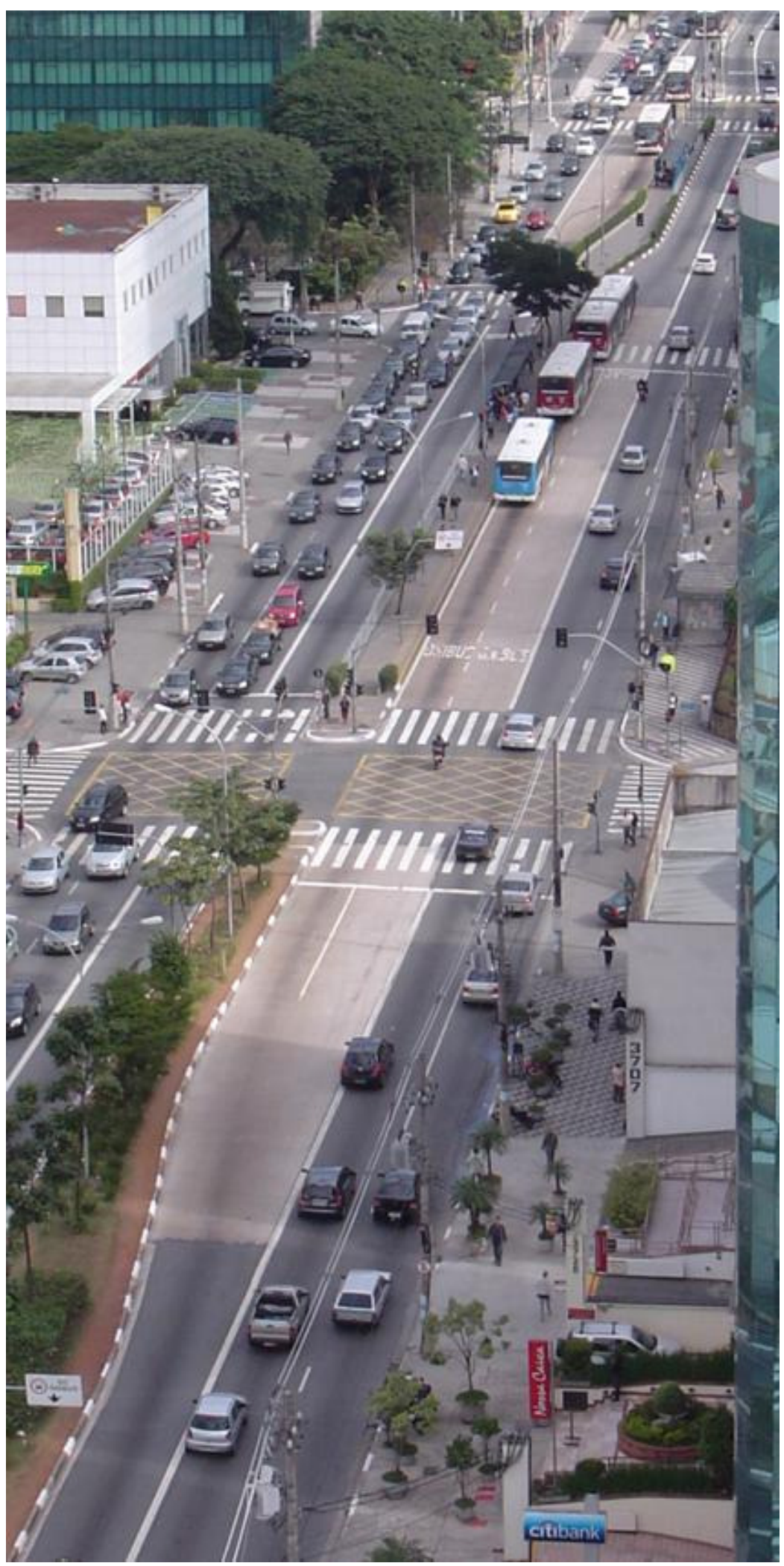

Figura 2 - Trecho de corredor de ônibus em São Paulo 
Segundo Schramm et al. (2010), um dos fatores que afeta diretamente o tempo de viagem em sistemas BRT é a possibilidade de ultrapassagem. Este fator torna-se mais importante a medida que a freqüência de ônibus aumenta, ou ainda em corredores com padrões de serviço onde ônibus não necessitam parar em todas as estações. Sistemas sem a possibilidade de ultrapassagem ao menos na região das estações forçam o ônibus esperar que 0 dianteiro finalize seu embarque/desembarque para prosseguir, o que causa atrasos.

\subsubsection{Bus Rapid Transit (BRT)}

Castro (2008) cita que uma das principais estratégias de ação no ramo de transportes, visando aspectos técnicos, econômicos e ambientais, é a melhoria dos sistemas de transporte público com a implantação de sistemas de corredores de ônibus e desempenho, que têm recebido na literatura técnica a denominação de Bus Rapid Transit (BRT).

Em função do limitado espaço físico viário nos grandes centros urbanos, a segregação de faixas ou pistas objetivam dar maior eficiência ao transporte público. Esse tipo de solução é conhecido internacionalmente como BRT e visa, em última análise, gerar maiores capacidades de transporte associadas a padrões elevados de conforto e segurança e maiores velocidades médias em relação aos níveis de serviço das formas convencionais de ônibus urbano (CASTRO, 2008).

Faz-se necessário priorizar o transporte público em sistemas como o BRT, frente um transporte individual por automóveis, em especial para grandes cidades e metrópoles de países em desenvolvimento, como o Brasil, que experimentam crescimento desordenado e contam com uma rede relativamente pequena de sistemas de transporte de massa como o metrô.

A abordagem deste trabalho prevê cinco possíveis tomadas de decisões (chamadas intervenções), conforme citado anteriormente. Essas intervenções obtêm melhores resultados quando aplicadas em sistemas de corredores de ônibus, uma das características do BRT. A Tabela 1 (abaixo) apresenta dados de corredores de 
ônibus na cidade de São Paulo - SP em 2005. Esta dissertação tem foco em um trecho do corredor Santo Amaro - Nove de Julho, penúltima linha da tabela apresentada. Na mesma, o corredor é apresentado com 14,5 kilômetros, mas este trabalho utilizou para estudo pouco menos que a metade do comprimento total deste corredor.

\begin{tabular}{|c|c|c|c|c|c|c|}
\hline Corredor & $\begin{array}{c}\text { Extensão } \\
(\mathrm{km})\end{array}$ & $\begin{array}{c}\text { Frota } \\
\left(^{\star}\right)\end{array}$ & $\begin{array}{c}\text { Pass./dia } \\
\text { útil }\end{array}$ & $\begin{array}{c}\text { Passageiros / } \\
\text { hora/sentido } \\
\text { (hora pico) }\end{array}$ & $\begin{array}{l}\mathrm{T}\left({ }^{\star \star}\right) \\
\text { médio } \\
(\mathrm{min} .)\end{array}$ & $\begin{array}{c}\mathrm{V} \\
\text { média } \\
(\mathrm{km} / \mathrm{h})\end{array}$ \\
\hline Rebouças & 10,3 & 790 & 470.000 & 15.600 & 35,0 & 17,0 \\
\hline Ibirapuera & 4,3 & 677 & 250.000 & 17.200 & 15,0 & 20,0 \\
\hline Itapecerica - João Dias & 8,4 & 457 & 140.000 & 8.600 & 25,0 & 20,0 \\
\hline Inajar - Centro & 12,5 & 560 & 200.000 & 9.400 & 40,0 & 19,0 \\
\hline Guarapiranga & 8,2 & 682 & 250.000 & 13.300 & 25,0 & 20,0 \\
\hline Rio Bonito & 26,8 & 974 & 460.000 & 11.700 & 80,0 & 20,0 \\
\hline Pirituba - Centro & 15,0 & 860 & 230.000 & 10.100 & 55,0 & 17,0 \\
\hline Santo Amaro - 9 de & 14,5 & 888 & 470.000 & 19.500 & 40,0 & 20,0 \\
\hline Paes de Barros & 4,0 & 122 & 70.000 & 5.600 & 13,0 & 22,0 \\
\hline TOTAIS & 104,0 & 6.010 & 2.540 .000 & & & \\
\hline
\end{tabular}

$\left.{ }^{*}\right)$ Valores referentes a todas as linhas que percorrem pelo menos um trecho do corredor

$\left.{ }^{* *}\right)$ O tempo médio e a velocidade média referem-se ao percurso da extensão total do corredor

Tabela 1 - Corredores de ônibus operando em São Paulo em 2005 (fonte: SPTrans, apud Castro, 2008)

$\mathrm{Na}$ tabela acima pode-se observar que o número de passageiros/hora/sentido (de pico) no corredor Santo Amaro - Nove de Julho (utilizado neste trabalho para simulações) é de 19.500. Como BRT é aplicado em diferentes cidades (com diferentes realidades), valores como este mencionado variam bastante, o que causa necessidade de ajustes no sistema como um todo. Nas simulações realizadas neste trabalho são considerados valores (como velocidade média no corredor) de BRT's de baixa demanda, como os implantados em Otawa e Brisbane (10.000 e 15.000 passageiros/hora/sentido, respectivamente). Já um BRT de Bogotá, por exemplo, possui números bem diferentes, como se observa na Tabela 2 (abaixo).

National BRT Institute (NBRTI) faz parte do Center for Urban Transportation Research (CUTR) da Universidade do Sul da Flórida - EUA. Este instituto publica 
relatórios diversos a respeito de BRT dos EUA e de outros países também. Em dois destes relatórios há dados quanto a velocidade média dos veículos, distância entre as estações e número médio de passageiros transportados por sentido por hora em diversos BRT's do mundo. Na tabela abaixo (Tabela 2) apresentam-se dados médios utilizando dois relatórios do NBRTI - um publicado em 2008 (HOFFMAN, 2008) e outro em 2009 (DIAZ; HINEBAUGH, 2009):

\begin{tabular}{|l|c|l|l|}
\hline Cidade & $\begin{array}{l}\text { Velocidade Média em } \\
\text { Horários de Pico } \\
\mathbf{( k m / h )}\end{array}$ & $\begin{array}{l}\text { Espaçamento } \\
\text { médio entre } \\
\text { estações } \mathbf{( m )}\end{array}$ & $\begin{array}{l}\text { Num. médio de } \\
\text { Passageiros/Hora/Sentido } \\
\text { em Horários de Pico }\end{array}$ \\
\hline Ottawa (Canadá) & 34 & 1.700 & 10.000 \\
\hline Bogotá (Colômbia) & 24 & 500 & 42.000 \\
\hline Brisbane (Austrália) & 60 & 1.300 & 15.000 \\
\hline
\end{tabular}

Tabela 2 - Dados do BRT de três cidades diferentes

Os dados da Tabela 2 mostram variação nas características de BRT's em diferentes localidades. Para este trabalho, as simulações apresentadas são baseadas em um BRT de baixa demanda, com as seguintes características: (1) estações mais espaçadas; (2) velocidades médias mais elevadas; e (3) número de passageiros transportados bem menores do que por exemplo os de Bogotá.

\subsection{Monitoramento de Frota}

Um sistema de monitoramento de frota é um sistema de coleta de informações das posições instantâneas dos ônibus que pode utilizar um receptor GPS. Com o uso de GPS's embarcados nos ônibus da frota, é possível determinar com precisão a localização espacial do veículo, velocidade desenvolvida, etc. Outras informações podem ser obtidas utilizando sensores diversos distribuídos no veículo, de modo que a central de monitoramento da frota também receba informações de condições gerais dos veículos como: situação dos freios, temperatura do motor, situação das portas, número de passageiros, etc. 
Baseado nas informações diversas recebidas de cada veículo, e nas informações como grade de horário, tráfego, itinerários, situação das estações, etc., é possível realizar um gerenciamento mais incisivo e interativo da frota.

A cada intervalo de tempo, computadores embarcados nos ônibus, chamados de AVL (Automatic Vehicle Location), aos quais está acoplado um equipamento GPS, transmitem instantaneamente dados (como velocidade e posição do veículo) para um centro de processamento de dados. O mesmo centro detém também informações sobre o itinerário referente a cada serviço dos ônibus. $E$ a partir da identificação local e temporal do veículo, é possível inferir sobre quanto tempo determinado ônibus levará para chegar à próxima estação. Dependendo desta informação, o algoritmo de tomada de decisão pode intervir no serviço. Essa intervenção afeta tanto o ônibus (como diminuir a velocidade ou não parar em alguma estação), quanto às estações (como por exemplo, se a estação possui painel de aviso dos próximos ônibus, este poderá ter que ser alterado).

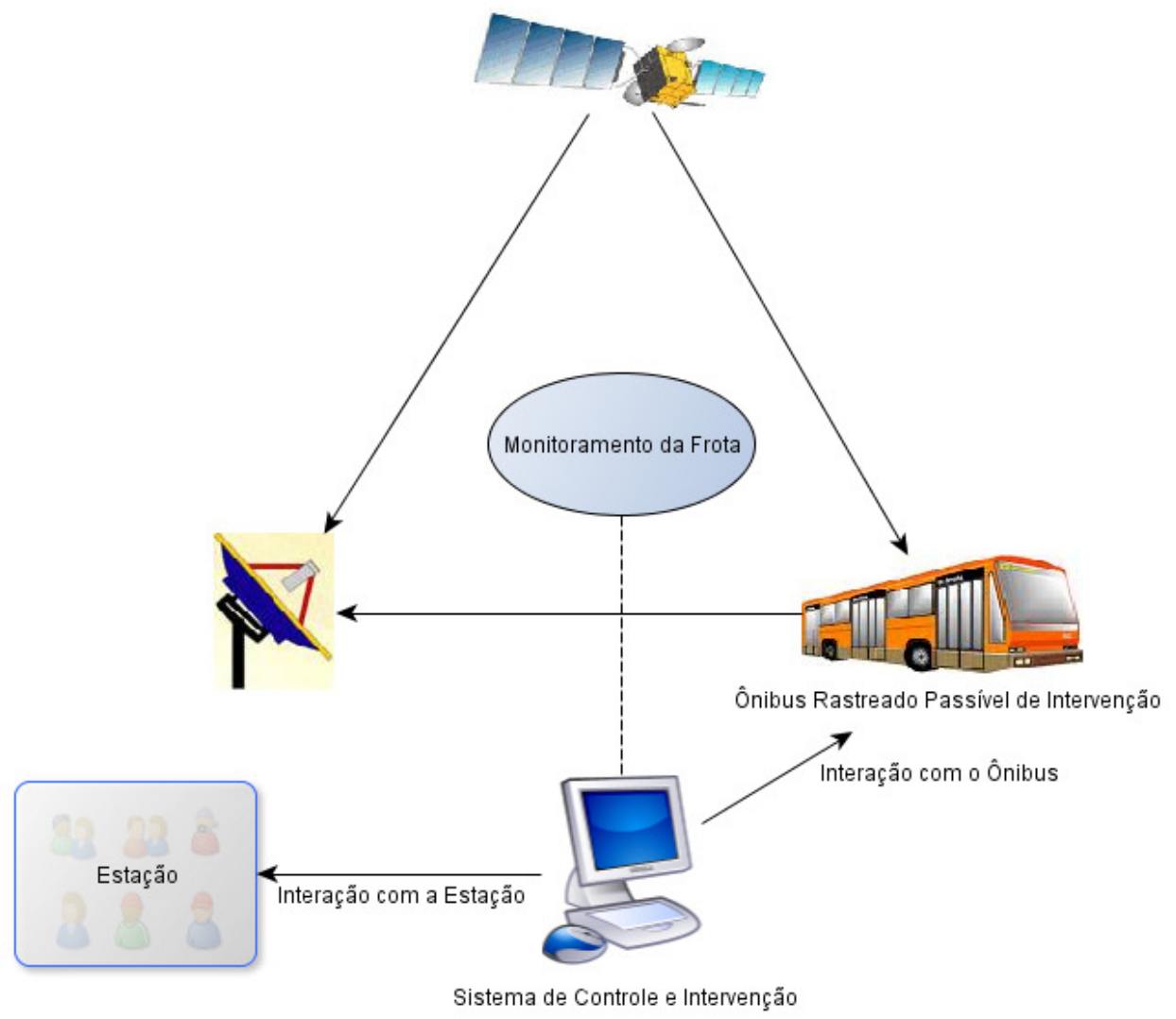

Figura 3 - Diagrama da descrição geral do processo 
A Figura 3 ilustra em termos gerais a estrutura da solução proposta. Um sistema de monitoramento informa os dados dos ônibus monitorados (incluindo as posições geográficas dos mesmos) para uma central de processamento de dados. Nesta central o sistema de identificação de inconformidades e intervenção nos serviços de ônibus faz uso dos dados provenientes do monitoramento e dos dados cadastrados no sistema (como grades de horários) para detectar e tentar corrigir possíveis inconformidades.

\subsubsection{GPS e AVL}

Segundo Cunha (2008), o monitoramento de veículos por sistemas AVL (Automatic Vehicle Location) que se utilizam da tecnologia GPS, possuem alto valor agregado em termos de informação em tempo real. Em outras palavras, o monitoramento AVL ocorre instantaneamente sobre dados de posições dos veículos em movimento atualizados dinamicamente, com conseqüente atualização dos atributos relacionados às posições (pontos GPS) em intervalos de tempo pré-definidos.

Rodrigues (2003, apud Cunha, 2008), cita AVL como sendo composto pelos subsistemas de aquisição dos dados e atuação, equipamentos embarcados, comunicação e gestão das informações. Alguns exemplos de tecnologia de posicionamento são os GPS embarcados em veículos, rede de telefonia celular, entre outros. Já os subsistemas de comunicação podem ser via rádio, telefonia móvel e satélite. De uma forma geral, o sistema coleta os dados de posicionamento dos veículos pelo subsistema de aquisição de dados, através do subsistema de comunicação, transmitindo-os a uma central de controle, onde é realizada a gestão das informações coletadas.

Segundo Bueno (2007, apud Cunha, 2008) O sistema americano Global Positioning System (GPS) é o mais difundido atualmente. Originalmente criado para uso militar, teve liberação para uso civil na década de 1980. Ele calcula a posição baseado em coordenadas geodésicas referentes ao sistema World Geodetic System 94 (WGS84). Outros sistemas de abrangência global, similares ao GPS, são o 
GLONASS (Global Navigation Satellite System), Galileo, EGNOS (European Geostationary Navigation Overlay Service), entre outros. O conjunto desses sistemas compõe o Global Navigation Satellite System (GNSS). O que eles têm em comum é a capacidade de geração de dados de localização (coordenadas, $x, y$ e z) e horário com alta acurácia.

Uma possível aplicação de monitoramento de frotas com o uso de AVL e GPS pode ser citada no caso de alguma ocorrência - como acidente, assalto, avaria mecânica, etc., utilizando-se um teclado/monitor específico ou rádio transmissor no ônibus que permita ao motorista comunicar imediatamente a ocorrência ao centro de controle. $O$ centro conhecerá a posição do veículo e importantes áreas estratégicas ao seu redor (como oficinas mecânicas, guincho, etc.) para tomar providências. $E$ em sentido inverso, a central de controle pode se comunicar com o motorista caso necessário.

\subsection{Tecnologia da Informação}

Devido à complexidade do modelo de sistema de transporte público urbano, 0 algoritmo de tomada de decisões de intervenções proposto pode não oferecer uma solução ideal, mas eficiente, já que são muitas as variáveis a serem analisadas para se tentar tomar uma decisão ótima (exemplo: análise de outros ônibus de mesmo serviço ao longo da linha - eles ficariam eqüidistantes após a intervenção escolhida?), o que torna inviável a análise como um todo, principalmente devido ao tempo de resposta do sistema, que dever ser baixo. Esse tipo de abordagem é conhecido como Heurística. Becceneri (2006, apud Carrara, 2007) define heurística como um método que, baseado na experiência ou julgamento, parece conduzir a uma boa solução de um problema, mas que não garante produzir uma solução ótima. Já para Brandeau e Chiu (1989, apud Carvalho, 2006), na heurística, ao invés de garantir uma solução ótima, utiliza-se um procedimento que reduz o processo de busca de soluções para encontrar uma solução satisfatória do problema, economizando-se o tempo de processamento. 
Pelo fato que tanto o modelo do sistema de transporte (cadastro, armazenamento e manipulação de informações dos ônibus, das estações, das grades de horários, etc.), quanto o algoritmo de tomada de decisão se baseiam em sistemas de informação, utilizou-se a Linguagem de Modelagem Unificada (UML) e o software Microsoft Visio, para modelagem do sistema. "UML é um modelo de linguagem que define uma notação que são todos os elementos de representação gráfica vistos no modelo" (MACORATTI, 2004). Assim, se identificam os agentes (atores), os casos de uso (acontecimentos comuns ao sistema) e os diagramas de seqüência e de classe (entidades do conceito UML que auxiliam no design e implementação de um sistema de informação).

As comparações entre qual o correto posicionamento de um ônibus em determinado dia/horário/serviço, qual a posição atual que não está conforme o desejado, e em qual posição o ônibus se encontra após seguir a ordem de intervenção (proveniente do algoritmo), podem ser observadas na forma de diagramas unifilares. Essas informações são geradas pelo servidor de mapas GeoServer baseado em coordenadas geográficas que representam a posição do ônibus em determinado dia e hora. Também se apresentam comparações de resultados, antes e após as intervenções realizadas pelo sistema, na forma de gráficos gerados pela planilha eletrônica Microsoft Excel ${ }^{\circledR}$.

GeoServer é um software tipo servidor, baseado na linguagem Java que permite aos usuários visualizar e editar mapas. Por utilizar padrões abertos de manipulação de dados espaciais segundo a Open Geospatial Consortium (OGC), GeoServer permite grande flexibilidade na criação de mapas e compartilhamento das informações espaciais (GEOSERVER, 2009). A OGC é uma organização internacional que lidera a adoção de padrões (inclusive implementando-os) e serviços web para dados espaciais (OGC, 2010).

Armazenou-se os dados espaciais no banco de dados gratuito PostgreSQL com extensão espacial PostGIS (que adiciona suporte de objetos geográficos ao PostgreSQL [http://www.postgis.org/]), e os dados puramente alfa-numéricos (não espaciais) no Microsoft SQL Server 2005 ®. Carregaram-se os dados nos bancos utilizando a Linguagem de Consulta Estruturada (SQL), formatada quando 
necessário em planilhas eletrônica Microsoft Excel ®. SQL é uma linguagem padrão para acessar bancos de dados de diferentes fabricantes (W3SCHOOLS, 2009). Segundo Pcmag (2009), SQL é uma linguagem usada para consultar e processar dados dentro de um banco de dados relacional.

Utilizaram-se a linguagem de programação C\# e o Ambiente de Desenvolvimento Integrado (IDE) de programas Microsoft Visual Studio 2005 ® (plataforma .NET). IDE pode ser entendido como um conjunto de programas que se executam através de uma única interface. Exemplo: interfaces de linguagem de programação freqüentemente incluem um programa editor de texto, um compilador e um debugador para auxiliar o desenvolvimento de programas (PCMAG, 2009).

Observando a necessidade de se manipular informações georreferenciadas em modelo de dados vetorial (tipo linha: rotas dos serviços; tipo pontos estáticos: estações; tipo ponto em movimento sobre as linhas: ônibus), o banco de dados PostgreSQL com extensão espacial PostGIS foi utilizado. E devido à necessidade de se visualizar as rotas, estações e ônibus, mesmo que de forma unifilar, o servidor de mapas GeoServer foi utilizado.

\subsection{Sistema de Informação Geográfica (SIG)}

A proposta deste trabalho é se obter um sistema de informação, baseado também em dados espaciais, com a finalidade de intervir na operação dos ônibus para obter melhores resultados, em comparação a sistemas de monitoramento de frota de ônibus baseados em um simples visualizador das posições de cada veículo e tomada de ações feitas apenas por um profissional humano.

Um SIG é, em poucas palavras, um sistema de informação que manipula dados geográficos (ou espaciais). Raia Junior (2000) cita um SIG como sendo a terminologia aplicada a tecnologia computacional orientada geograficamente.

Segundo Santos e Ferreira (2004), o planejamento urbano de trânsito e transportes encontra no Sistema de Informação Geográfica um aliado eficiente na resolução de problemas. Além disso, SIG na área de transportes demanda grande quantidade de 
informações sobre a malha viária destacando principalmente o traçado das vias, sentido de tráfego, permissões de conversão, tipos de pavimentação, nomes de via, entre outras informações. Atualmente existe uma grande utilização de SIG aplicadas ao planejamento de transportes, sendo utilizado com maior freqüência para o registro e acompanhamento de ocorrências. Outros exemplos de aplicações de SIG são:

- Monitoramento de veículos através de receptores GPS;

- Roteamento na logística de cargas;

- Análise de rotas de menor custo (de tempo, distância, etc.);

- Manutenção da estrutura envolvida como sinalização, por exemplo.

Propõe-se então a implementação de um sistema de informação geográfica que avalie uma série de dados de entrada (grades de horário, posições dos ônibus, variáveis configuradas no sistema como tempo de aceitação de atraso, etc.) e baseado em algoritmos heurísticos, produza como dados de saída as intervenções (tomadas de decisão relativas ao ônibus). Um algoritmo heurístico pode não apresentar uma solução ótima ou boa para todos os casos do problema que se propõem a resolver, característica importante para abordagens como deste trabalho que interage com variáveis complexas na tomada de decisões de intervenções.

Neste trabalho utiliza-se SIG para se detectar as inconformidades (o não cumprimento da grade horária) dos ônibus, auxiliar na execução dos algoritmos de intervenção, e apresentar os resultados de forma unifilar requisitando informações de serviços web de mapas.

\subsubsection{Definições de SIG}

Para Carrara (2007), SIG pode ser definido como uma coleção organizada de hardware, software, dados geográficos e de recursos humanos. 
Dias (2001) trabalhou com dados cartográficos, além de dados textuais, o que gerou a necessidade da utilização de um sistema capaz de suportar cartografia também. $O$ mesmo autor cita um SIG como um sistema capaz de estocar dados (geograficamente referenciados) em banco de dados, de forma que possam ser graficamente consultados e sumarizados.

Silva (1998) cita que o nível de sofisticação de programas computacionais alcançou tal ponto, que realizam diversas operações complexas ao mesmo tempo. E alguns deles combinam, por exemplo, em um só produto, recursos dos SIG com modelos e técnicas tradicionais de planejamento de transportes. O autor ainda define um SIG em sua essência, como a combinação de imagens de mapas com diferentes tipos de informação, e cita que o SIG tem aplicações não apenas no planejamento de transportes, mas em inúmeras outras áreas, incluindo o planejamento urbano.

Outras definições encontradas:

- Sistemas automatizados utilizados para armazenar, analisar e manipular dados geográficos (CÂMARA et al., 1996);

- Sistema baseado em computador, que permite ao usuário coletar, manipular e analisar dados georreferenciados (TEIXEIRA; CHRISTOFOLETTI, 1997);

- Conjunto de ferramentas informáticas feitas para a aquisição, armazenamento, análise e representação de dados espaciais (ORDÓÑEZ; MARTINEZ, 2003).

Neste trabalho o uso de SIG é fundamental para cálculos necessários ao sistema de monitoramento e intervenção, bem como apresentação dos resultados. 


\section{BUS RAPID TRANSIT}

O documento mais extenso (e completo em relação a BRT) utilizado neste trabalho é o livro (na sua versão em português) intitulado Manual de BRT - Bus Rapid Transit Guia de Planejamento. Sua versão original (em inglês) é de responsabilidade do Institute for Transport and Development Policy (ITDP). O ITDP, segundo consta no seu website oficial (http://www.itdp.org/), foi fundado em 1985 e se tornou uma organização líder na promoção de políticas de transporte ambientalmente sustentáveis com projetos em diversos países de todo mundo. Ele foi criado nos Estados Unidos da América por defensores da tendência de transporte sustentável com o objetivo de ser contra a dependência do transporte em relação aos automóveis privados. Mais recentemente, o ITDP tem focado seu trabalho em desenvolver nos países em desenvolvimento, com o intuito de implementar projetos que mostrem como a poluição do ar, emissões de carbono, congestionamento e acidentes de tráfego podem ser reduzidos.

\subsection{Introdução}

O acesso a empregos, educação e serviços públicos é parte das necessidades fundamentais para o desenvolvimento humano. Mas muitas cidades desistiram do verdadeiro transporte público, deixando as necessidades de mobilidade nas mãos dos veículos particulares. As conseqüências já são conhecidas: congestionamentos, poluição do ar e sonora, acidentes, etc. Um sistema de transporte público de alta qualidade ainda é um elemento indispensável no desenvolvimento de uma cidade onde as pessoas e comunidade vêm em primeiro lugar (BRASIL, 2007). Peñalosa (2009), ex-prefeito de Bogotá e Presidente do ITDP, foi incisivo no seminário proferido na EPUSP a respeito de cidades com ênfase nos pedestres e não em automóveis. Ele deixou clara a necessidade de expandir a utilização de calçamentos dedicados à circulação de pessoas, e transporte público baseado em sistemas BRT, como forma de suprir as necessidades das cidades quanto à mobilidade, 
acessibilidade e qualidade de vida. Essa abordagem é bem ilustrada na capa do Manual BRT que pode ser vista na Figura 4:

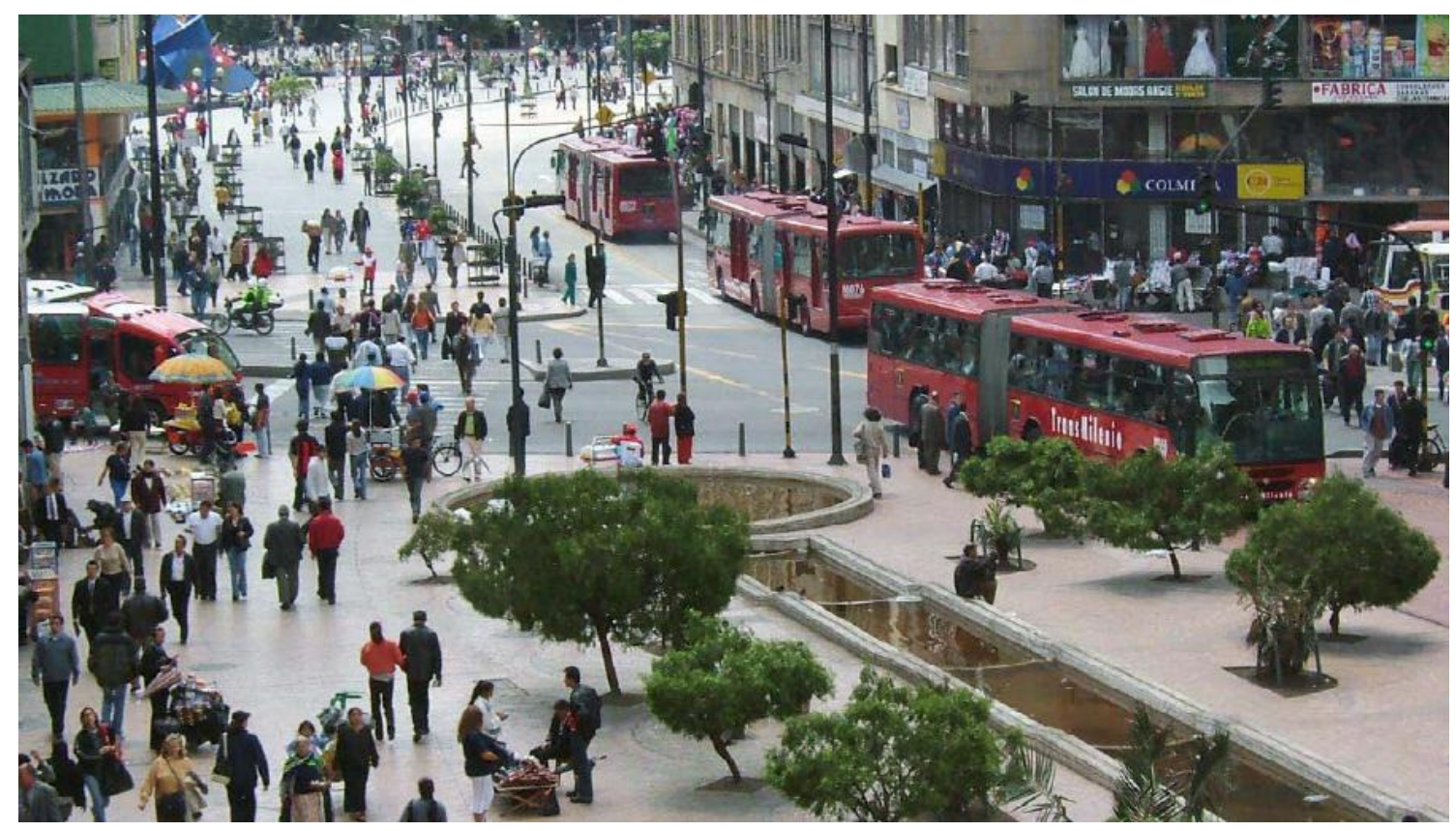

Figura 4 - TransMilenio de Bogotá (foto por Karl Fjellstrom - Brasil, 2007)

Um transporte público eficiente é central para o desenvolvimento. Para a vasta maioria dos residentes de cidades em desenvolvimento, o transporte público é, na prática, a única maneira de acessar empregos, educação e serviços públicos. 0 atual estado dos serviços de transporte público nas cidades em desenvolvimento normalmente contribui pouco para atender as reais necessidades de mobilidade da população. Serviços de ônibus são freqüentemente pouco convenientes, inseguros e de baixa confiança. Em resposta, planejadores de transporte público e autoridades têm muitas vezes se voltado para outras alternativas de transporte de massa, extremamente custosas, como metrôs ferroviários. Graças aos altos custos de infraestrutura das linhas férreas, as cidades só podem construir esses sistemas ao longo de poucos kilômetros e em poucos corredores limitados. O resultado é um sistema que não atende às principais necessidades de transporte da maior parte da população. O BRT é uma alternativa que pode oferecer alta qualidade de serviço, similar ao metrô, por uma fração do custo das outras opções (BRASIL, 2007).

Segundo Brasil (2007), o BRT é cada vez mais reconhecido como umas das 
soluções mais eficientes para oferecer serviços de transporte de alta qualidade a custos eficientes em áreas urbanas, tanto nos países desenvolvidos quanto em países em desenvolvimento. O aumento da popularidade do BRT como solução viável para a mobilidade urbana é enfatizado pelo sucesso de implementação pioneiras em cidades como Curitiba, Bogotá e Brisbane. E como a segurança energética e a ameaça da mudança climática se tornaram tópicos relevantes que preocupam todas as nações, oferecer transporte público efetivo deveria ser um objetivo fundamental para todas as cidades, independentemente de sua denominação econômica. Mas o BRT sozinho não resolverá a miríade de problemas sociais, ambientais e econômicos que desafiam os centros urbanos mundo afora, mas mostrou como um catalisador efetivo na transformação das cidades em ambientes mais habitáveis e amigáveis.

Wright (2010) refere-se ao BRT como a solução de melhor custo/benefício para muitas cidades ao redor do mundo. Segundo o autor, BRT tem redefinido o que é possível em termos de transporte público: sistemas com faixas de trânsito segregadas para os ônibus, serviços rápidos e freqüentes, rotas e corredores integrados, estações seguras e protegidas, etc. Ao final da primeira década do século 21, aproximadamente 100 sistemas BRT estão operando, e um número próximo disso está em desenvolvimento, em diversos locais do mundo.

A importância de BRT é foco de diversos setores, incluindo o privado. Um bom exemplo é a empresa Volvo, que possui um centro de pesquisa chamado Research and Education Foundation (VREF), onde uma das linhas de pesquisa é a respeito de BRT. Segundo o website do Massachusetts Institute of Technology - MIT (2010), um consórcio entre o próprio MIT e o Instituto Superior Técnico de Portugal (ISTPortugal) obteve da VREF, 3,5 milhões de dólares para um centro de excelência em BRT (este é o oitavo centro de excelência em BRT fundado pela VREF, segundo notícia publicada no referido site em 28/04/2010), onde Juan Carlos Muñoz (PUC Chile), Nigel Wilson (MIT) e José Viegas (IST) são os principais envolvidos. O primeiro objetivo deste centro é desenvolver um novo framework para planejamento, design, financiamento, implementação e operação de BRT em diferentes áreas urbanas, oferecendo uma direção correta a seguir para os tomadores de decisão envolvidos com BRT. 


\subsection{Definindo o Bus Rapid Transit}

Bus Rapid Transit (BRT) é um sistema de transporte de ônibus que proporciona mobilidade urbana rápida, confortável e com custo eficiente através da provisão de infra-estrutura segregada com prioridade de passagem, operação rápida e freqüente e excelência em marketing e serviço ao usuário (BRASIL, 2007).

O BRT basicamente imita as características de desempenho e conforto dos modernos sistemas de transporte sobre trilhos, mas a uma fração do custo. Um sistema BRT custa, em geral, entre 4 a 20 vezes menos que um sistema de bondes ou de veículo leve sobre trilhos (VLT) ou entre 10 a 100 vezes menos que um sistema de metrô (BRASIL, 2007).

Outras três definições de BRT:

"Modo de transporte público sobre pneus, veloz e flexível, que combina estações, veículos, serviços, vias e elementos de sistema inteligente de transporte (ITS) em um sistema integrado com uma forte identidade positiva que evoca uma única imagem." (Levinson et al., 2003, p. 12, apud Brasil, 2007).

"BRT é um transporte público de alta qualidade, orientado ao usuário, que realiza mobilidade urbana rápida, confortável e de custo eficiente." (Wright, 2003, p. 1, apud Brasil, 2007).

"Um modo de transporte rápido que consegue combinar a qualidade dos transportes férreos e a flexibilidade dos ônibus." (Thomas, 2001, apud Brasil, 2007).

Essas definições indicam que o BRT se distingue do serviço de ônibus convencional. De fato, as definições tendem a sugerir que o BRT tem muito mais em comum com sistemas ferroviários, especialmente em termos de desempenho operacional e serviço ao usuário. BRT incorpora os aspectos mais valorizados pelos usuários de VLT e metrô e faz com que esses atributos se tornem acessíveis para um número maior de cidades devido ao seu menor custo. 
Sistemas BRT também diferem-se entre si por diversos fatores, entre eles: (1) faixas de velocidade de tráfego; (2) tamanhos de veículos; (3) tipos de combustíveis, (4) faixas de demanda (2 a 45 mil pessoas/hora/sentido); etc. (BRASIL, 2007). Este trabalho destina-se a ter como base sistemas BRT que operem nas faixas mais baixas de demanda (pessoas/hora/sentido), aquelas onde o trabalho proposto é aplicável.

\subsection{Características do BRT}

Segundo BRASIL (2007), os elementos que constituem o conceito de BRT incluem:

- Operações eficientes: serviços rápidos e freqüentes entre as principais origens e destinos; ampla capacidade para demanda de passageiros ao longo dos corredores; embarques e desembarques rápidos; cobrança e controle de pagamento antes do embarque; integração tarifária entre linhas, corredores e serviços alimentadores.

- Arranjos institucionais e de negócio eficazes e transparentes: entrada no sistema restrita a operadores prescritos, sob uma estrutura administrativa e de negócios reformada; licitação competitiva e processos transparentes na premiação de contratos e concessões; sistema de cobrança de tarifas operado e gerenciado por entidade independente; fiscalização do controle de qualidade por uma entidade/agência independente.

- Infra-estrutura de qualidade: vias segregados de ônibus ou faixas exclusivas; rede integrada de corredores e linhas; estações modernas que propiciam acesso em nível ao veículo; estações especiais e terminais que facilitam a integração física entre linhas troncais; melhoramentos no espaço público próximos ao sistema BRT. A Figura 5 ilustra o nível de qualidade de transporte em massa oferecido com o BRT: 


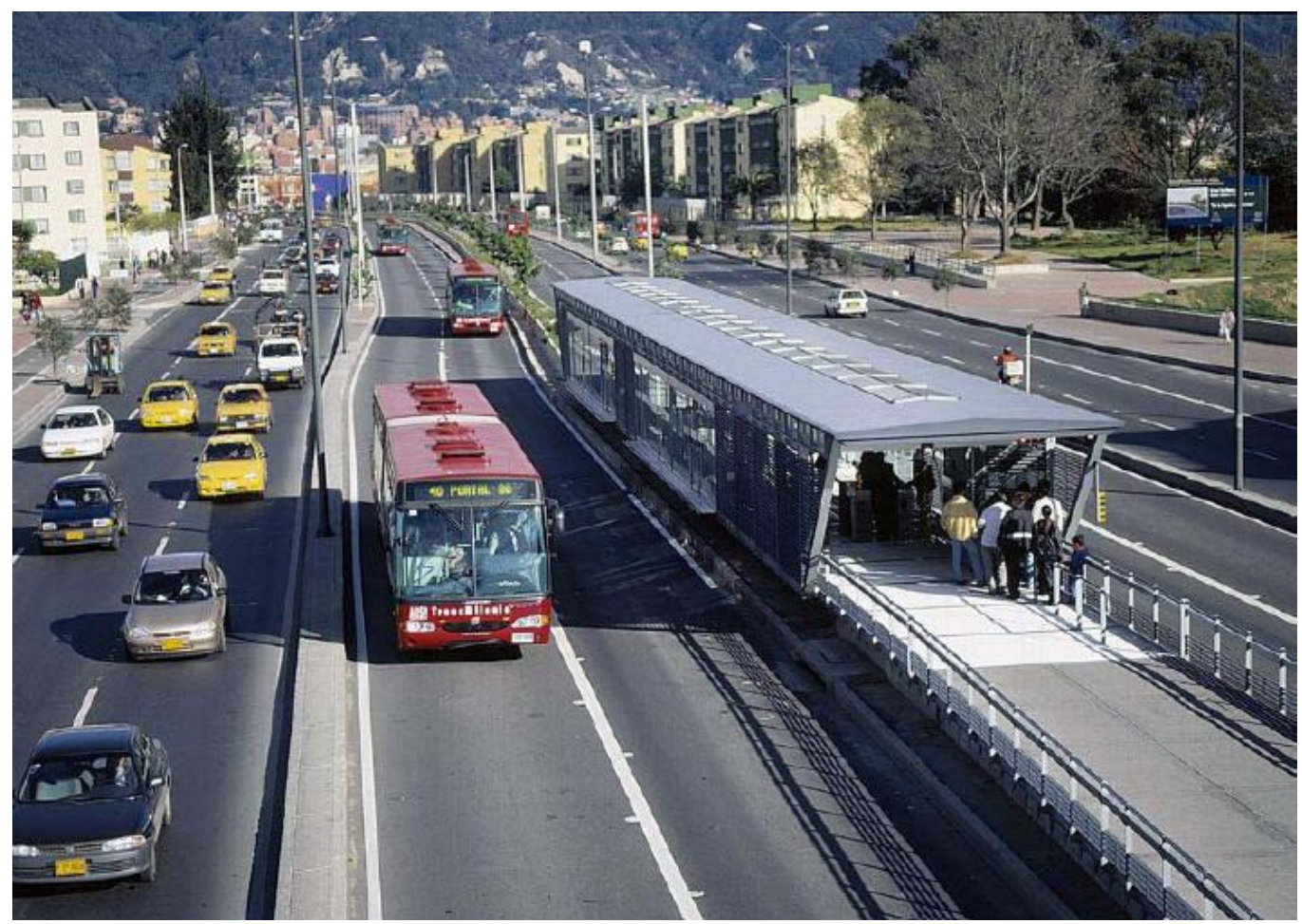

Figura 5 - Corredor do sistema TransMilenio em Bogotá (foto por cortesia de Volvo Bus Corporation para o Manual de BRT - p. 11)

- Tecnologia sofisticada: tecnologias veiculares de baixos ruídos e emissões de gases; cobrança e verificação de tarifas automatizadas; sistema de gerenciamento por controle centralizado, utilizando aplicações de Sistemas de Tráfego Inteligente, tais como localização automática de veículos; prioridade semafórica ou separação física nas intersecções.

- Excelência em marketing e serviço ao usuário: sistema com identidade de mercado distinta; excelência em serviços ao usuário e oferecimento de utilidades essenciais aos usuários; facilidade de acesso entre o sistema e demais opções de acessibilidade urbana (bicicletas, táxis, etc.); providências especiais para facilitar o acesso aos portadores de necessidades especiais como crianças, idosos e deficientes físicos.

E para a realização de um sistema de BRT bem sucedido, o Manual de BRT (Brasil, 2007) detalha seis grandes áreas de planejamento:

1. Preparação do Projeto: (1) Início, (2) Tecnologias, (3) Configuração, (4) Análise, (5) Seleção de corredores, (6) Comunicações. 
2. Projeto Operacional: (7) Projeto de rede e linhas, (8) Capacidade e velocidade do sistema (descreve a velocidade média de um BRT de qualidade como sendo entre 23 a $39 \mathrm{~km} / \mathrm{h}$ ), (9) Interseções e controle de semáforos, (10) Serviço ao usuário.

3. Projeto Físico: (11) Infra-estrutura, (12) Tecnologia.

4. Integração: (13) Integração Modal, (14) Integração com gerenciamento de demanda e uso do solo.

5. Plano de Negócios: (15) Estrutura institucional e de negócios, (16) Custos operacionais e tarifas, (17) Financiamento, (18) Marketing.

6. Avaliação e Implementação: (19) Avaliação, (20) Plano de implementação.

Não é objetivo deste trabalho descrever e analisar cada um desses vinte itens citados, apresentam-se aqui apenas para detalhar mais a abrangência do BRT.

\subsection{BRT na Prática}

\subsubsection{Empresa1}

Empresa1 é uma empresa brasileira com sede em Belo Horizonte, especializada em soluções de bilhetagem eletrônica para ônibus, trem e metrô, e vias no padrão BRT. A Empresa1 realiza gestão de frota (monitoramento e rastreamento) através de um GPS embarcado e com comunicação via GPRS. Esta tecnologia permite o monitoramento do veículo com acesso em tempo real a informações para o controle da frota e tomada de decisões operacionais. Vantagens e diferenciais (EMPRESA1, 2010):

- Rastreamento via GPS embarcado informa posicionamento da frota em tempo real;

- Visualização dinâmica da informação; 
- Envio de informações operacionais para a central;

- Possibilidade de executar ações corretivas de forma ágil;

- Canal de voz entre a central e o veículo;

- Possibilidade de comunicação com o passageiro através de canal de voz dentro do ônibus e painéis de aviso nas paradas e estações;

- Possibilidade para realizar recarga e bloqueio de cartões online.

No início de 2010, a Empresa1 divulgou ser responsável pela integração das soluções tecnológicas dos sistemas de transporte massivo e coletivo na América Central, que beneficiará mais de 4 milhões de habitantes. Segundo a Empresa1 (2010), o projeto compreende o transporte massivo BRT integrado a um amplo sistema de transporte coletivo com linhas alimentadoras. Neste contexto de integração, a empresa M2M é a responsável pela solução de Gestão de Frota, Monitoramento, Rastreamento e Sistema de Informação ao passageiro. A M2M fornecerá os módulos GPS/GPRS para toda a frota, além do software de retaguarda para o gerenciamento das informações oriundas destes módulos.

\subsubsection{M2M}

A M2M oferece soluções para gestão de frota de ônibus em tempo real, o que permite o controle das ações da frota e possibilita conhecer o comportamento dos ônibus para que a operação reaja às mudanças e imprevistos em tempo real (M2M, 2010). Na solução proposta pela M2M, implanta-se uma sala central de controle com softwares especializados em monitoramento de ônibus. Sensores instalados nos ônibus enviam dados dos mesmos para a sala de controle. Alguns exemplos destes dados são: excesso de tempo parado, desvio de rota, e cumprimento de viagem. A M2M possui um software para ser instalado e utilizado na sala de controle onde as rotas são mapeadas de forma a monitorar a operação dos ônibus. A transmissão de dados em tempo real garante, ao usuário do sistema, informações preciosas para tomada de decisões (M2M, 2010). 
Quanto a comunicação, a M2M (2010) cita que são poucas as opções para uma comunicação funcional entre a central de controle e o motorista do ônibus. O uso de aparelhos de viva-voz é proibido pela atual legislação, e terminais de dados requerem tempo (e desvio de atenção do motorista) para leitura e digitação. Assim, a M2M desenvolveu uma solução de comunicação específica para veículos coletivos urbanos, composto de uma seqüência de luzes (painel com LED's) para interagir com o motorista, não interferindo em sua atenção ao trânsito. Estas luzes são configuráveis de acordo com o a necessidade do utilizador, mas a M2M cita os seguintes exemplos:

- Verde: autorização para continuar viagem pois há outro veículo chegando no ponto regulador.

- Amarelo: ordem para reduzir a velocidade, pois o intervalo entre o outro ônibus está curto.

- Vermelho: solicitação para que entre em contato com a central, pois há alteração de rota.

\subsubsection{TACOM}

TACOM, empresa com mais de 40 anos de experiência no mercado de transportes, possui dois produtos diretamente relacionados com este trabalho: CITGIS e CITBRT. Segundo a TACOM (2010), o CITBRT tem total conformidade com o conceito de ITS (Sistema Inteligente de Transporte), que disponibiliza sistema de informação ao usuário (CITSIU) e controle operacional da frota (CITCCO). CITSIU é o sistema de informação ao usuário composto por painéis (LCD) informativos, tanto nas estações (previsão de chegada dos ônibus) quanto dentro dos ônibus (informa o ponto onde o ônibus está parada e qual o próximo ponto). A localização geográfica é feita com auxílio de GPS durante todo o trajeto e o sistema calcula o tempo de chegada aos pontos. A transmissão dos dados é feita via GPRS (TACOM, 2010). CITCCO é conceito da TACOM para o centro de controle operacional equipado com tecnologia de ponta que proporciona ao operador, através de informações georreferenciadas 
em tempo real, acesso a dados como: localização exata do veículo ao longo do corredor; headway (intervalo entre viagens ou distância entre veículos); envio de mensagens da central para os passageiros, do motorista para a central e da central para o motorista. Assim realiza uma gestão on-line de seus veículos, tomando medidas corretivas quando necessário (TACOM, 2010). Ainda segundo a TACOM (2010), o CITGIS permite o acompanhamento de aspectos do sistema de transporte e também possibilita ações corretivas em tempo real. A possibilidade de fazer mudanças rápidas favorece todos: os passageiros ficam menos tempo esperando nos pontos; os gestores podem incrementar a mobilidade urbana; e os empresários racionalizam a utilização de seus ônibus. O CTIGIS é um sistema de monitoramento georreferenciado via GPS, com envio de informações em tempo real via GPRS, e pode ser operado em um Centro de Controle Operacional. Algumas das funcionalidades do CTIGIS são:

- Atualização dinâmica do quadro de horários dos ônibus (ajuste entre demanda e oferta).

- Envio de mensagens da central para os passageiros, do motorista para a central e da central para o motorista.

- Instalação de painéis de avisos nas paradas ou estações de embarque, com a previsão de chegada do próximo ônibus.

- Controle de headway (intervalo entre viagens ou distância entre veículos), evitando o agrupamento de veículos e conseqüente desequilíbrio entre a oferta e a demanda.

- Cumprimento de horários.

- Análise de velocidade.

\subsection{BRT - Política}

Tanto Peñalosa (2009), quanto Lindau et al. (2008), abordam a questão política do BRT como sendo muitas vezes mais impactante na implantação de um BRT, do que 
a parte técnica propriamente dita. Lindau et al. (2008) cita o caso de Porto Alegre onde investimentos dos setores público e privado foram utilizados no transporte público com sucesso. Conclui ainda que a parceria público-privada representa um oportunidade em projetos BRT, inclusive em outros países da América Latina e do mundo.

No caso do BRT de Curitiba, o setor público foi o grande responsável pelo sucesso do BRT. Curitiba tem uma longa história (aproximadamente quatro décadas) de inovações em transporte, uso do solo e gerenciamento ambiental. Nos anos 2009 e 2010, a cidade recebeu novos corredores de ônibus, e aumento de capacidade em um já existente (Lindau et al., 2010). Curitiba é a sétima cidade mais polulosa do Brasil, totalizando 3,17 milhões de habitantes na área metropolitana, população esta que cresceu 2,1 vezes nos últimos 20 anos (IBGE, 2010, apud Lindau et al., 2010). A cidade conseguiu alcançar o que outras cidades brasileiras com similares condições não conseguiram - ser um dos melhores exemplos de integração entre transporte e uso de solo (Fouracre, 1975; Cervero, 1998, apud Lindau et al., 2010). Cidades como São Paulo, Belo Horizonte, Recife, Porto Alegre e Rio de Janeiro usaram financiamento federal disponibilizado em meados de 1970 somente para melhorar performance de sistemas de ônibus, enquanto Curitiba usou esta oportunidade de investimento, em corredores de ônibus direcionado para o crescimento futuro da cidade (Lindau et al., 2010). Curitiba pode ser considerada como o berço do BRT com a introdução das vias de ônibus arteriais e alimentadoras em 1970, além da criação de uma Rede de Trânsito Integrada (RTI), em 1980, que inclui sistema de pré-pagamento, acesso aos ônibus em nível, e grandes ônibus com múltiplas portas (Lindau et al., 2010). Criou-se em 1965, por iniciativa política, o Instituto de Pesquisa e Planejamento Urbano de Curitiba (IPPUC), o qual dedicou-se às operações de ônibus com características como as faixas segregadas para trânsito. O sistema de ônibus urbano de Curitiba foi gradualmente melhorado, até alcançar o status de primeiro BRT completo do mundo (Arias et al., 2008, apud Lindau et al., 2010).

O caso de Curitiba ilustra bem a dependência política existente para que um bom gerenciamento das cidades ocorra, neste caso no que se refere ao transporte público. 


\section{ESPECIFICAÇÃO DA SOLUÇÃO}

Neste capítulo é apresentado como se procede para identificar as inconformidades, quais as ações possíveis que o sistema pode selecionar (e qual a lógica para tanto), e como se dá a comunicação entre sistema e motorista e passageiros. Também se apresenta o design do sistema, tecnologia utilizada, banco de dados e fluxogramas explicativos sobre os algoritmos utilizados.

\subsection{Identificação de inconformidades}

O sistema proposto conta com o cadastro da grade de horários dos serviços, ou seja, em que horários os ônibus de um serviço devem visitar as estações. Também pelo sistema se tem a informação de quais ônibus estão vinculados a quais serviços. Mas, do ponto de vista da identificação de inconformidades, não se leva em conta se um ônibus específico está atrasado ou adiantado, e sim, em quanto tempo o próximo ônibus (mais próximo) chegará à estação. Essa estimativa de tempo é possível utilizando-se uma simples fórmula da física $(\mathrm{Vm}=\mathrm{E} / \mathrm{T})$ que relaciona:

- Velocidade Média (Vm): dado atrelado ao trecho onde se encontra o ônibus, e que pode ainda ser obtido a partir de dados históricos de variação de velocidade conforme dia da semana e horário.

- Espaço a ser percorrido (E): dado que se trata de um sistema de informação geográfica, é possível calcular qual distância existe entre a posição corrente do ônibus em determinado momento até a próxima estação onde ele deve parar.

- $\quad$ Tempo (T).

A estação se responsabiliza em analisar a situação dos ônibus e intervir quando necessário. Verifica-se a cada $x$ minutos (valor configurável no sistema, identificado aqui pela sigla ITV [intervalo de tempo para verificação]), quais ônibus (de diferentes 
serviços) deveriam chegar em menos de y minutos (valor configurável no sistema, identificado aqui pela sigla ITPO [intervalo de tempo para próximo ônibus]) nas estações, baseando-se nas posições correntes dos ônibus e nos dados das rotas e grades horárias dos serviços. Verifica-se então, percorrendo em sentido contrário ao fluxo dos serviços, onde se encontram os próximos ônibus a chegarem nas estações. E finalmente, identifica-se a ocorrência ou não de dois tipos de inconformidades: ônibus atrasado e ônibus adiantado. Segue mais abaixo a lógica para identificar inconformidades. As seguintes siglas serão consideradas:

- TG: tempo que o ônibus deveria levar até chegar à estação baseado na grade de horário;

- TO: tempo que o ônibus levará até chegar à estação, calculado pela velocidade e distância;

- DT: diferença entre TO e TG;

- VTAT: valor de tolerância de ônibus atrasado (valor configurável no sistema);

- VTAD: valor de tolerância de ônibus adiantado (valor configurável no sistema).

1- Ônibus atrasado: o ônibus será considerado atrasado se DT, no momento da verificação, for positiva e maior VTAT.

2- Ônibus adiantado: o ônibus será considerado adiantado se DT, no momento da verificação, for negativo e seu valor absoluto for maior que VTAD.

\section{Exemplos:}

1- Estação $E$ verificou que um ônibus $O$ do serviço $S$ deve chegar em 8 minutos (TG). Percorrendo a rota em sentido contrário ao fluxo do serviço, a estação verificou que o próximo ônibus tem tempo de chegada estimado em 21 minutos (TO). Como DT (TO - TG) é positivo, compara-se DT (13) com VTAT (que nesse exemplo é 5) e conclui-se que há um atraso de 13 minutos. Lógica considerada: Se (DT > VTAT), então há atraso de DT minutos.

2- Estação $E$ verificou que um ônibus $O$ do serviço $S$ deve chegar em 8 minutos (TG). Percorrendo a rota em sentido contrário ao fluxo do serviço, a 
estação verificou que o próximo ônibus tem tempo de chegada estimado em 2 minutos (TO). Como DT (TO - TG) é negativo, compara-se |DT| (6) com VTAD (que nesse exemplo é 4) e conclui-se que há um adiantamento de 6 minutos. Lógica considerada: Se [(DT < 0) e $(|D T|>V T A D)]$, então há adiantamento de $|\mathrm{DT}|$ minutos.

\subsection{Ações que o sistema pode solicitar}

Conforme apresentado anteriormente, são cinco as possíveis intervenções que o sistema pode efetuar, e são dois os tipos de inconformidades (ônibus atrasado e ônibus adiantado). Seguem detalhes de cada intervenção:

A) ADIANTAR - para quando o ônibus está atrasado:

- AD_PE (adiantar - pular estação): Se solicita ao motorista que não pare na próxima estação. A regra básica para decidir se é possível optar por essa intervenção é simples. Se não há pedido de passageiro para parar na próxima estação, pode-se executar o "salto" da estação em questão. A verificação de existência de solicitação de parada por parte de algum passageiro pode ficar a cargo do motorista, o que simplifica o algoritmo. Essa decisão afeta os painéis internos de aviso de próximas estações dos ônibus, os painéis de aviso de próximos ônibus das estações, bem como esses mesmos avisos de itinerário em forma sonora, caso haja.

- AD_OE (adiantar - solicitar ônibus extra): Alocação de outro ônibus para suprir atrasos significativos. Em locais estratégicos ao longo dos corredores, ônibus-reserva estarão de plantão para entrar em serviço caso ocorra um atraso muito significativo. $\mathrm{O}$ sistema se baseia em outra variável configurável (VLOE - valor limite para escolha de intervenção tipo ônibus extra) para concluir se o atraso demanda necessidade de solicitar um ônibus extra. Em caso positivo, o ônibus atrasado se retirará de serviço quando chegar ao ponto final. 
B) ATRASAR - para quando o ônibus está adiantado:

- AT_DV (atrasar - diminuir velocidade): Solicita-se ao motorista que diminua a velocidade. De uma maneira geral, para os casos onde o ônibus está adiantado, a intervenção de diminuir a velocidade (sem impactar no tráfego dos outros ônibus) é a primeira escolha do algoritmo, desde que a distância até a estação seja considerada o suficiente para que a alteração da velocidade surta efeito. Para isso existe a variável DROE (configurável no sistema) que é comparada com a distância do ônibus até a estação e dependendo do resultado a intervenção AT_DV é selecionada pelo algoritmo. Esta é uma intervenção que deve respeitar a velocidade mínima dos corredores de ônibus e o fluxo de veículos no mesmo.

- AT_EB (atrasar - esperar no buffer): Solicita-se ao motorista que estacione no local de espera (buffer) para não acumular veículos nas docas (local de embarque/desembarque). A intervenção de esperar no buffer é de baixo impacto no sistema já que não gera tráfego, mas cria a necessidade de locais de estacionamento com acesso fácil ao corredor. Isso pode ser um problema, já que a existência de locais livres para utilização dessa natureza não seja tão comum nos grandes centros urbanos onde espaço costuma ser um bem raro (e caro). De qualquer maneira é uma opção que deve ser considerada de forma a auxiliar em outras situações como em caso de ônibus avariados que precisam estacionar até serem removidos dos corredores.

- AT_ED (atrasar - esperar na doca): Solicita-se ao motorista que permaneça por maior tempo estacionado na doca, desde que não haja outros ônibus esperando para utilizar a doca em questão. Caso haja, o ônibus deve sair da doca e o motorista poderá por conta própria utilizar a ação de diminuir a velocidade (AT_DV) para voltar a cumprir sua grade horária (antes que o sistema novamente identifique a inconformidade e ele receba novamente a informação que continua adiantado). Por esse motivo o sistema avisa ao motorista o quanto (em minutos) adiantado ele está. 


\subsection{Comunicação com motoristas e passageiros}

Uma ordem de intervenção como por exemplo "saltar estação" pode ser enviada ao motorista facilmente, mas os painéis informativos de itinerário dentro dos ônibus ou nas estações também necessitam ser alterados neste caso. As comunicações realizadas no sistema proposto são:

- Mensagens visuais enviadas ao motorista (saltar estação, sair ou entrar em serviço em determinada estação, desacelerar, esperar no buffer ou na doca);

- Comandos de voz ao motorista (instruções para situações fora do normal, alteração de rota);

- Painéis dentro dos ônibus indicando posição atual e itinerário (próximas estações e tempo estimado);

- Painéis nas estações indicando próximos ônibus com horários previstos de chegada.

\subsection{Demais Considerações}

Seguem agora considerações gerais a respeito do sistema como regras, siglas, definições de termos utilizados no modelo da solução proposta e tecnologia utilizada:

- A modelagem do sistema suporta o cadastramento de estações, serviços, ônibus, etc., de forma a se obter o controle completo da rede de transporte composta por muitos ônibus e serviços. Mas neste trabalho realizaram-se simulações e intervenções sobre apenas um serviço em um segmento de corredor de ônibus com aproximadamente sete kilômetros.

- Há um sistema maior (sistema central que detém todas as informações necessárias para identificação das inconformidades e tomada de decisão de intervenção) responsável pelo cadastro geral dos diversos componentes do modelo de gerenciamento da frota de ônibus, e que também realiza a 
parametrização de diversas variáveis envolvidas na detecção de inconformidades e lógica de execução do algoritmo que toma as decisões de intervir ou não nos serviços. As variáveis configuradas diretamente em uma das telas do sistema central são:

1. ITV: intervalo de tempo para verificação da situação de cada estação;

2. ITPO: intervalo de tempo a se monitorar o próximo ônibus que deve chegar;

3. VTAT: valor de tolerância antes de considerar o ônibus como ATRASADO;

4. VTAD: valor de tolerância antes de considerar o ônibus como ADIANTADO;

5. VLOE: valor limite para considerar intervenção ônibus extra;

6. VDOE: valor limite da distância do ônibus até a estação (nos casos de ônibus adiantado, este valor será comparado com a distância real do ônibus até a estação [DROE] para verificar a possibilidade de intervenção do tipo Diminuir Velocidade).

- No sistema maior, acessado via credenciais de autenticação por nome de usuário e senha de acesso, os componentes do sistema de gerenciamento de transporte coletivo por ônibus que podem ser incluídos, excluídos e alterados são:

1. Dias da Semana: podem-se cadastrar diferentes dias da semana (incluindo feriados) para se obter possibilidade de regras de negócio diferentes em diferentes dias (como diferentes demandas em caso de feriados);

2. Serviço: é composto de uma rota que o ônibus deve cumprir em determinado dia da semana, prestando serviço de embarque e desembarque em estações pré-definidas;

3. Trecho: arco que interliga duas estações. Possui dados de velocidade média e limite de velocidade, além do comprimento do mesmo. Localizado espacialmente por coordenadas geográficas; 
4. Estação: local onde se efetua embarque e desembarque de passageiros. Pode ou não possuir painel de aviso aos usuários. Está atrelada a um trecho (montante). Localizada espacialmente por coordenadas geográficas;

5. Grade Horária: para um serviço há uma seqüência pré-estabelecida de estações que devem ser visitadas em determinados horários;

6. Doca: local dentro da estação onde se realiza o embarque e desembarque de passageiros Está associado a uma estação;

7. Buffer: local próximo das docas onde é possível estacionar um ônibus mas não é permitido realizar embarque/desembarque de passageiros. Está associado a uma estação;

8. Local Standby: local estratégico onde ficam os ônibus estacionados para os casos em que haja necessidade de entrarem em serviço caso o sistema assim ordene. Localizada espacialmente por coordenadas geográficas;

9. Ônibus: veículo que cumpre a grade-horária de determinado serviço. Localizado espacialmente (e instantaneamente) por coordenadas geográficas;

10. Ônibus em Serviço: indica qual ônibus cumpre qual serviço;

11. Período do Dia: devido diferenças de necessidades de transporte ao longo das 24 horas do dia, diferentes períodos (Ex: 05:00 às 09:00; 09:00 às 16:00; 16:00 às 00:00, e 00:00 às 05:00) são cadastrados no sistema (não há limite de quantidade), indicando hora inicial e final de um intervalo horário do dia em questão;

12. Tempo Gasto na Estação: tempo médio gasto para embarque/desembarque de passageiros em uma estação, num determinado dia e período.

- Tecnologia utilizada: foram escolhidos dois bancos de dados (um espacial e outro não), uma interface de desenvolvimento e um servidor de mapas para implementação da solução. São eles, respectivamente: 
1. Banco de Dados Espacial PostGIS 1.4 (PostgreSQL 8.4).

2. Banco de Dados Alfa-Numérico Microsoft SQLServer 2005 ®.

3. IDE de desenvolvimento de sistemas Visual Studio 2005 ® plataforma .NET - Linguagem C\#.

4. Servidor de mapas GeoServer 2.0.1 (requisições de dados via serviços web de mapas e visualizador OpenLayers [API gratuita e de código fonte aberto, desenvolvida em JavaScript para apresentar e manipular os dados provenientes dos serviços web de mapas dentro de navegadores de internet]).

\subsection{Design do Sistema}

Neste capítulo são apresentados diagramas, telas e a estrutura do banco de dados do sistema desenvolvido (segundo o Modelo Entidade Relacionamento [MER]). Fileto (2003) define MER como sendo um modelo baseado na percepção do mundo real, que consiste em um conjunto de objetos básicos chamados entidades e nos relacionamentos entre esses objetos. Conclui ainda que esse tipo de modelo tem como objetivo facilitar o projeto do banco de dados, possibilitando especificar a estrutura lógica geral do banco. MER's são muito utilizados na área de sistemas que utilizam banco de dados (uma grande parte utiliza), auxiliando também na implementação do sistema.

\subsubsection{Telas e Diagramas de Casos de Uso e de Seqüência}

Nogueira (2005) define Unified Modeling Language (UML) como um modelo de linguagem para modelagem de dados orientado a objetos, usado para especificar, construir, visualizar e documentar um sistema de software. Cita ainda que com ele é possível realizar uma modelagem visual de maneira que os relacionamentos entre 
os componentes do sistema sejam melhor visualizados, compreendidos e documentados. UML introduz o conceito de casos de uso, além de diagramas que auxiliam na estruturação do software a ser construído.

Casos de Uso especificam o comportamento do sistema e descrevem a funcionalidade do sistema desempenhada pelos atores. Um caso de uso pode ser compreendido como um conjunto de cenários, onde cada cenário é uma seqüência de passos a qual descreve uma interação entre um usuário e o sistema (NOGUEIRA, 2005).

Tiago (2010) define um Ator como uma entidade externa ao sistema que de alguma forma participa do caso de uso. Um ator pode ser um ser humano, máquinas, dispositivos ou outros sistemas. Atores típicos são: cliente, usuário, gerente, computador, impressora, etc.

Chitnis et al. (2003) citam que um Diagrama de Seqüência é muito útil para elaborar e detalhar designs dinâmicos e a seqüência e origem de invocação de objetos. Um diagrama de seqüência se constitui de objetos (representados por retângulos) e mensagens (representadas por linhas).

\subsubsection{Acesso ao Sistema}

Como muitos sistemas de informação, o aqui proposto contém uma tela inicial (Figura 6) onde se informam dados de acesso ao sistema para que o mesmo possa aplicar diferentes permissões/comportamentos, dependendo do usuário que acessou o sistema, além de registrar as utilizações dos usuários. Diferentes permissões dentro de um sistema de informação são utilizadas para que o mesmo sistema possa ser operado por pessoas com diferentes funções e aptidões. E o registro da utilização do sistema por usuário auxilia em possíveis melhorias e correção de defeitos do sistema, bem como em auditorias. 


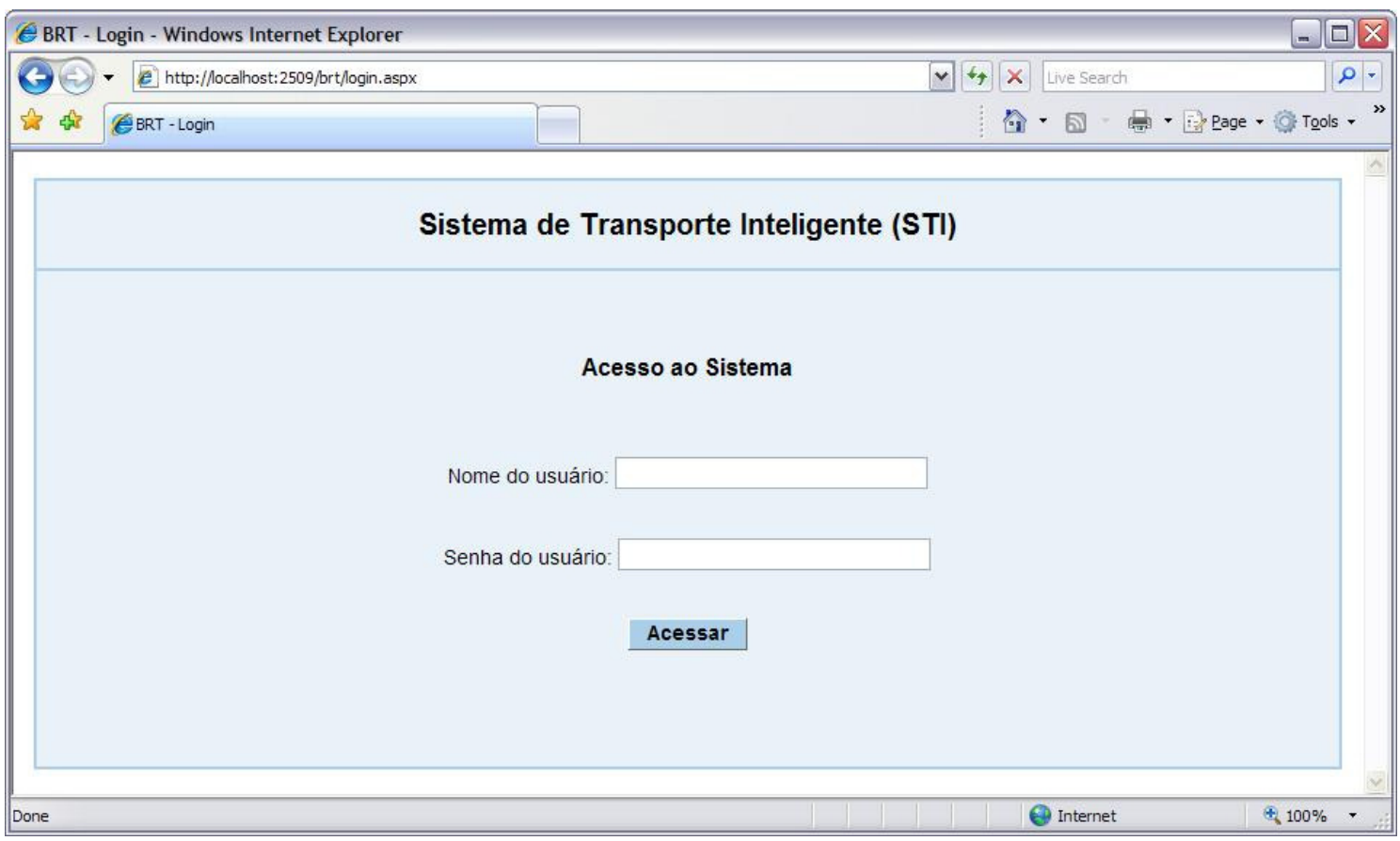

Figura 6 - Tela inicial para acesso ao sistema

\section{Diagrama de Caso de Uso}

Segue abaixo (Figura 7) o diagrama de caso de uso para acessar o sistema:

uc Acessar Sistema

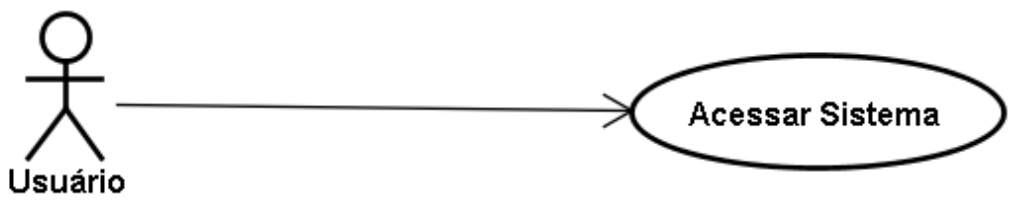

Figura 7 - Diagrama de caso de uso Acessar Sistema 


\section{Diagrama de Seqüência}

Segue abaixo (Figura 8) o diagrama de seqüência para acessar o sistema:

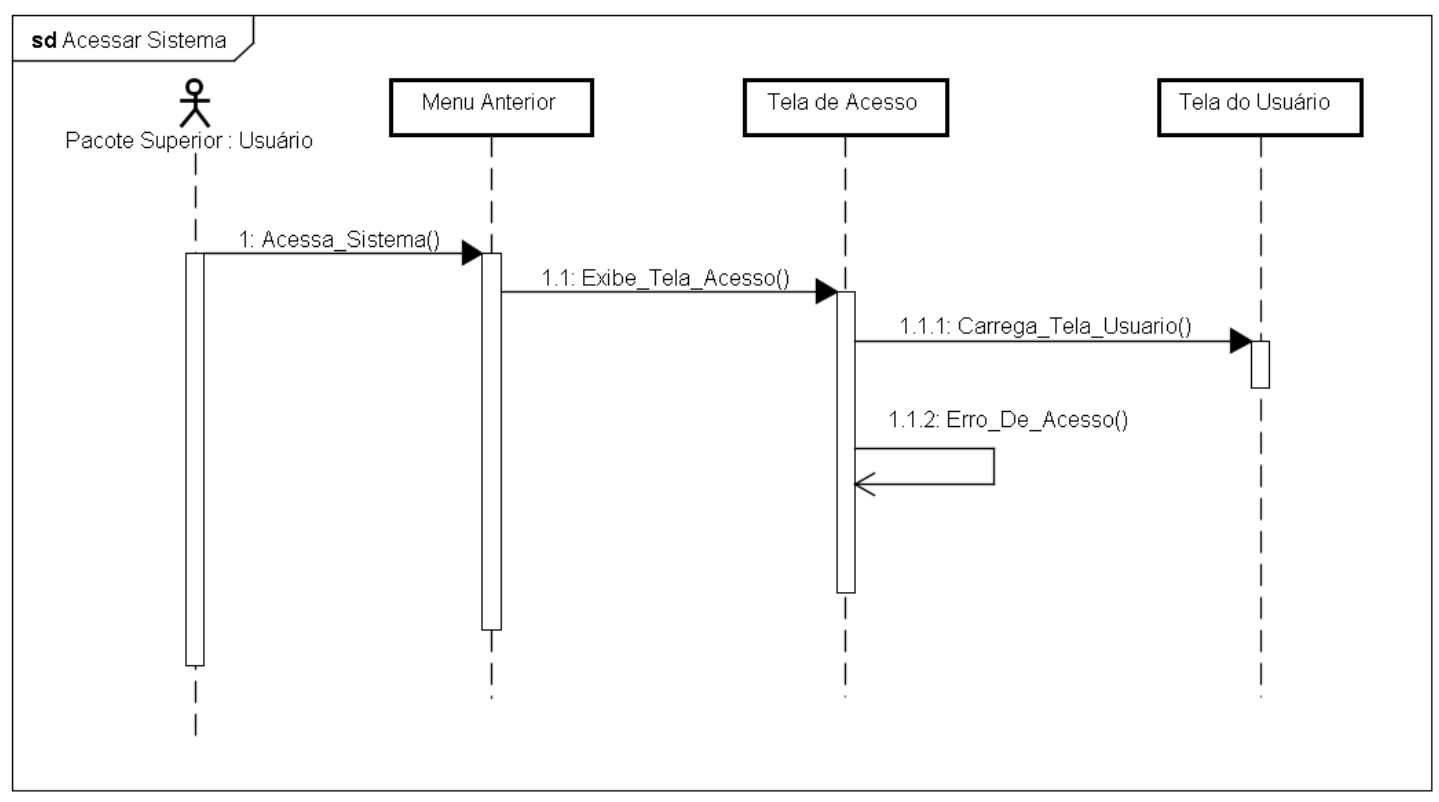

Figura 8 - Diagrama de seqüência Acessar Sistema

\section{Considerações}

$\mathrm{Na}$ tela inicial do sistema (Figura 6) o usuário preenche os dois campos (Nome e Senha) para ter acesso ao menu principal do mesmo (Figura 9). Os dados por ele informados são consultados no banco de dados e, caso inválidos, uma mensagem é apresentada ao usuário, permanecendo o sistema na mesma tela de modo que o usuário possa informá-los novamente. Quando os dados são válidos, a tela de menu do sistema é apresentada ao usuário. Segue abaixo (Figura 9) a tela visualizada por usuários com permissão para todas as opções de menu do sistema após a tela de acesso: 


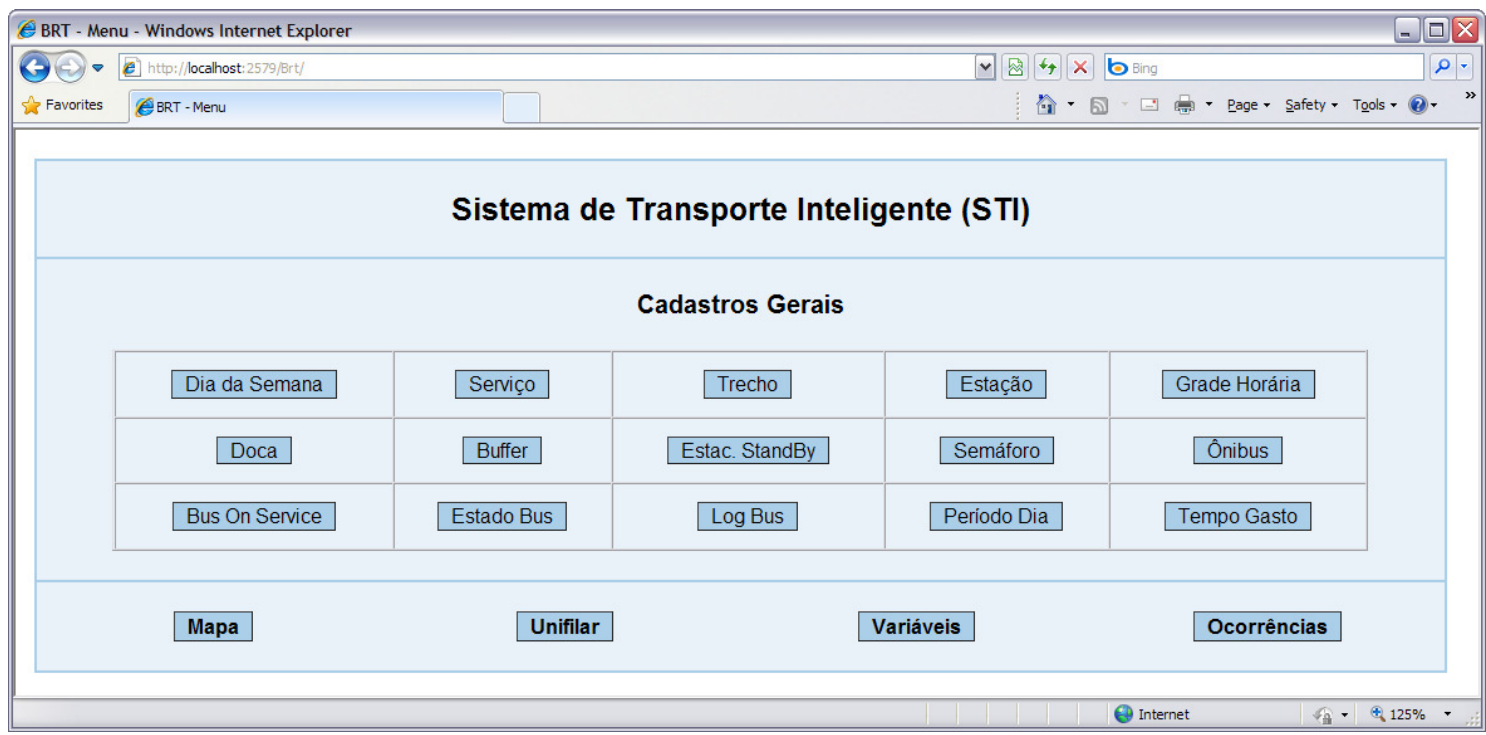

Figura 9 - Tela de menu do sistema

$\mathrm{Na}$ tela de menu do sistema observa-se uma grade de três linhas por cinco colunas. Cada botão dentro dessa grade é utilizado para abrir uma nova tela onde se visualiza, altera, insere e exclui registros de cadastro. Essa gama de informações é a base para que a identificação de inconformidades seja possível. Ao clicar no botão Log Bus (linha 3, coluna 3) por exemplo, apresenta-se uma tela com as informações do monitoramento de frota que contém: data, hora, identificação do ônibus e coordenadas geográficas.

Em seguida (item 6.1.2) apresentam-se tela e diagramas do cadastro de docas e buffers das estações. Não serão apresentadas todas as telas e diagramas de todos os cadastros do sistema pois são similares ao cadastro de docas e buffers agora apresentados, além de que a quantidade de telas de cadastro é extensa.

\subsubsection{Cadastro de docas e buffers por estação}

A tela de menu do sistema deixa clara a grande quantidade de informações que se deve cadastrar para obterem-se os dados do modelo proposto de gerenciamento dos serviços de ônibus. Segue abaixo (Figura 10) a tela de cadastro de docas e buffer por estação e os diagramas de caso de uso e seqüência. 


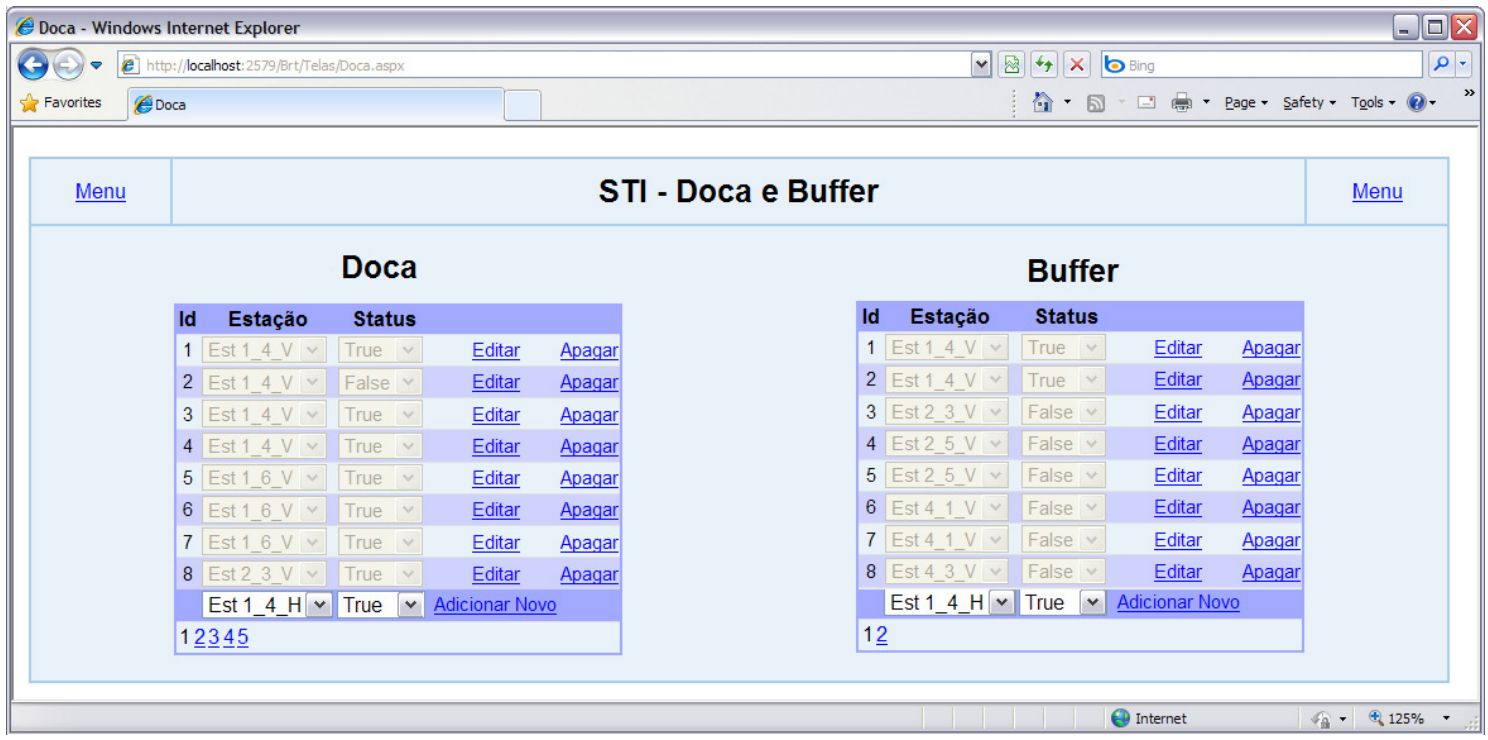

Figura 10 - Tela para cadastrar docas e buffers

\section{Diagrama de Caso de Uso}

Segue abaixo (Figura 11) o diagrama de caso de uso para cadastro de docas e buffers:

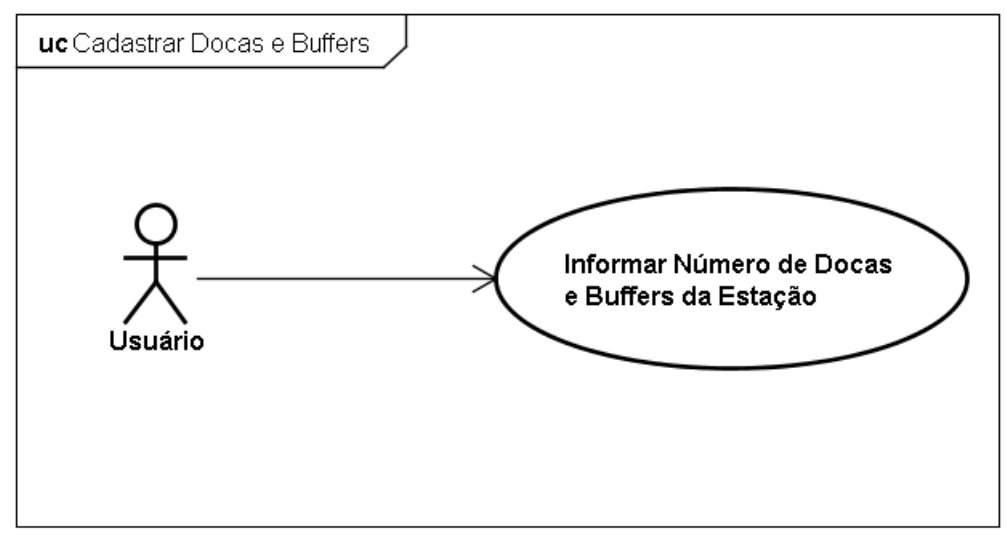

Figura 11 - Diagrama de caso de uso Cadastrar Docas e Buffers

\section{Diagrama de Seqüência}

Segue abaixo (Figura 12) o diagrama de seqüência para cadastro de docas e buffers: 


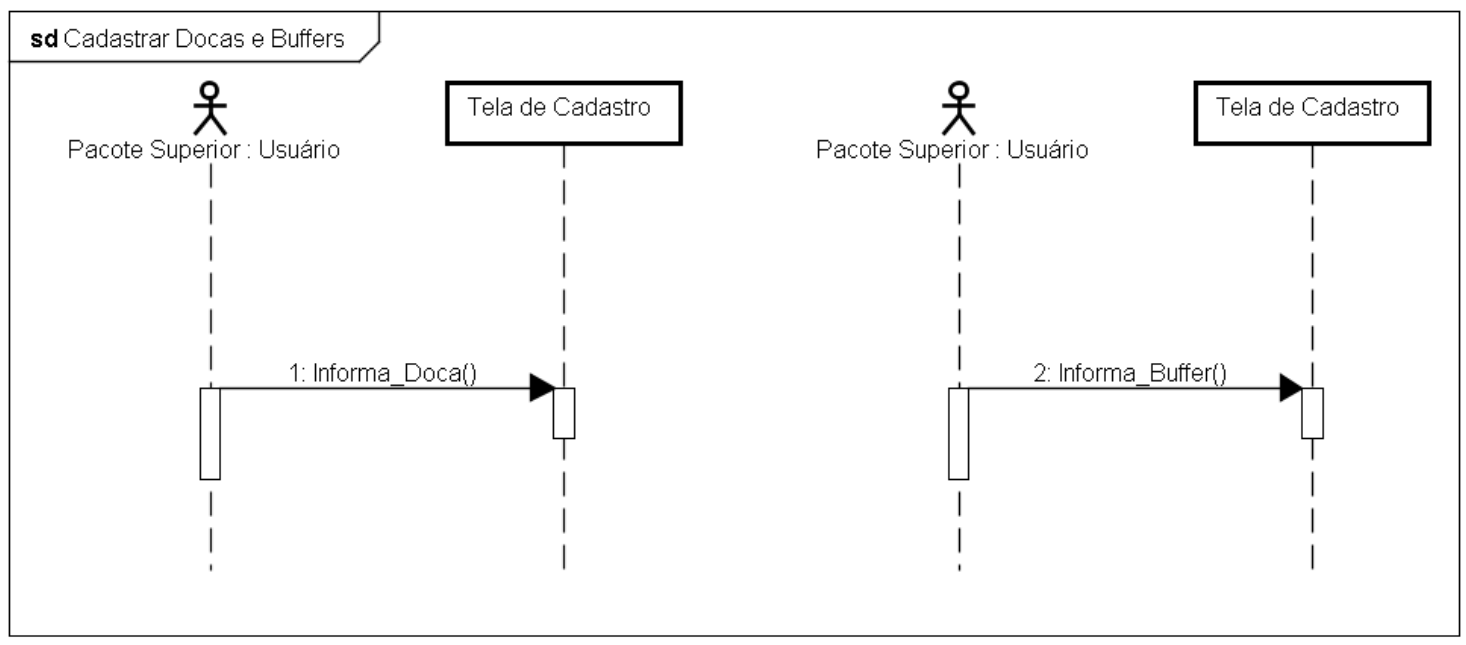

Figura 12 - Diagrama de seqüência Cadastrar Docas e Buffers

\subsubsection{Cadastro de grade de horários}

Segue abaixo (Figura 13) uma amostra da tela do sistema para cadastro de grades de horários:

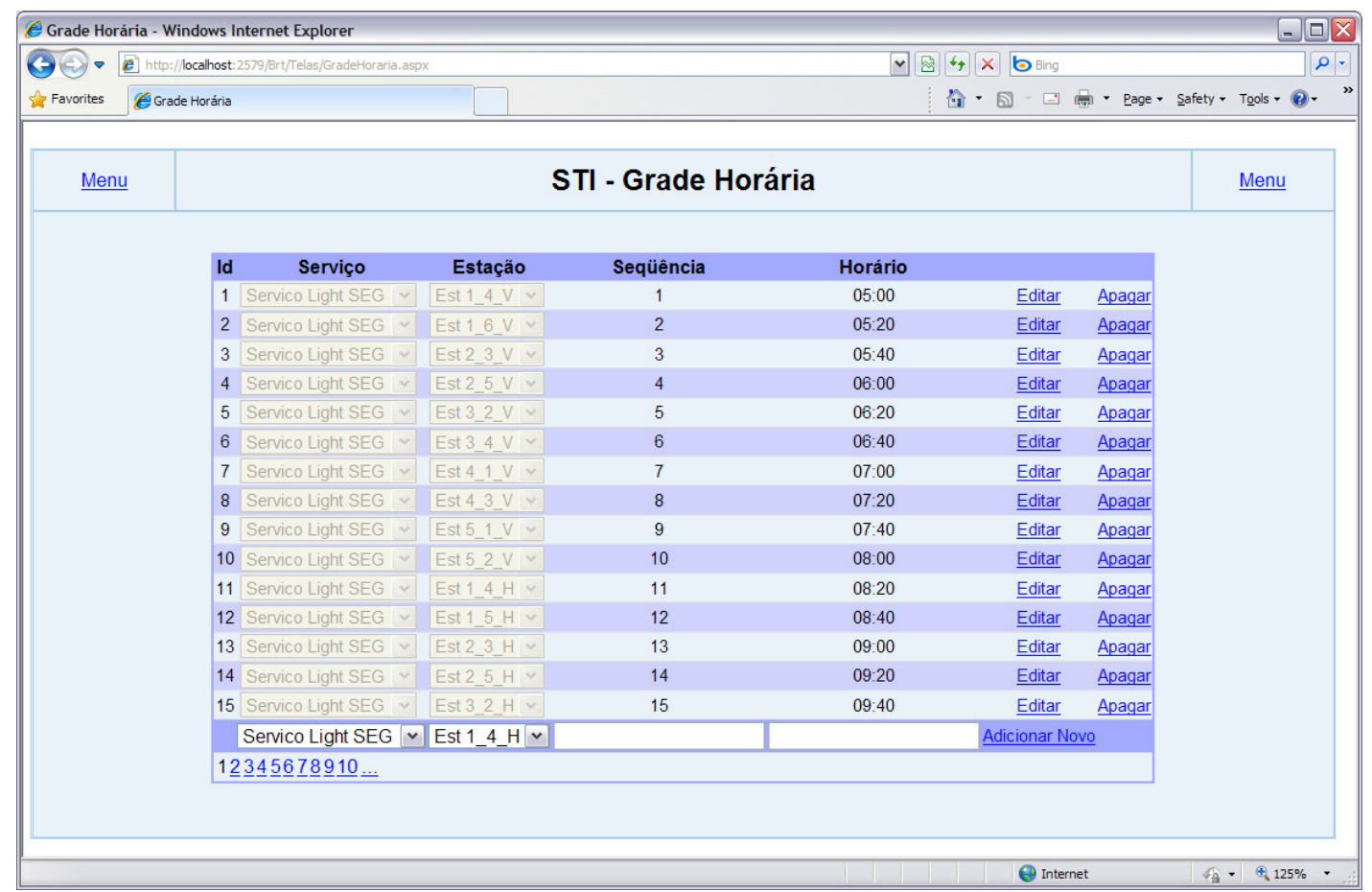

Figura 13 - Tela para cadastrar grade de horários

No modelo proposto, o cadastro de grade de horários deve ser realizado informando 
o Serviço (previamente cadastrado em outra tela), a Estação (também previamente cadastrada) e o Horário. Em outras palavras: para o serviço $A$, na estação $B, O$ ônibus irá estar nos seguintes horários. Existe um campo auxiliar (Seqüência) que pode ser informado para auxiliar na visualização dos dados e consultas.

\section{Diagrama de Caso de Uso}

Segue abaixo (Figura 14) o diagrama de caso de uso para cadastro de grades de horários:

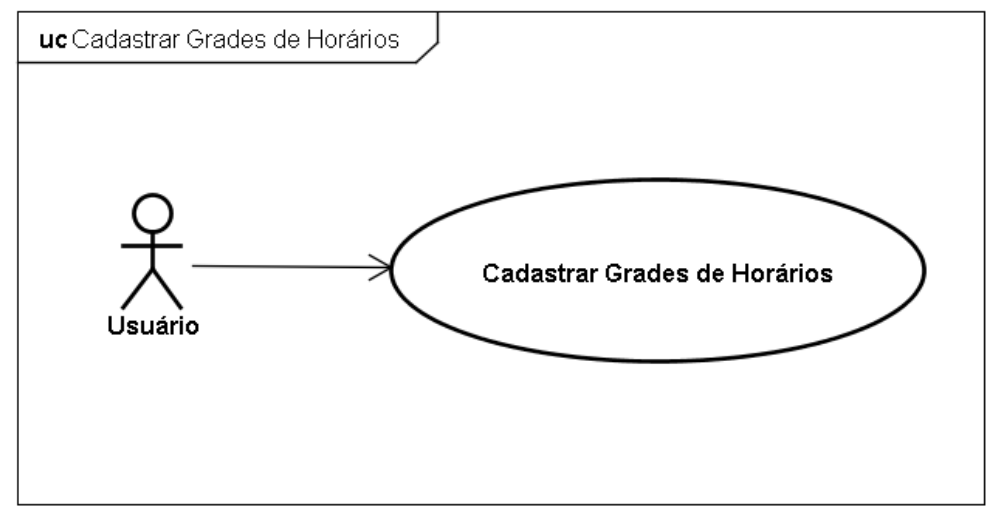

Figura 14 - Diagrama de caso de uso Cadastrar Grades de Horários

\section{Diagrama de Seqüência}

Segue abaixo (Figura 15) o diagrama de seqüência para cadastro de grades de horários:

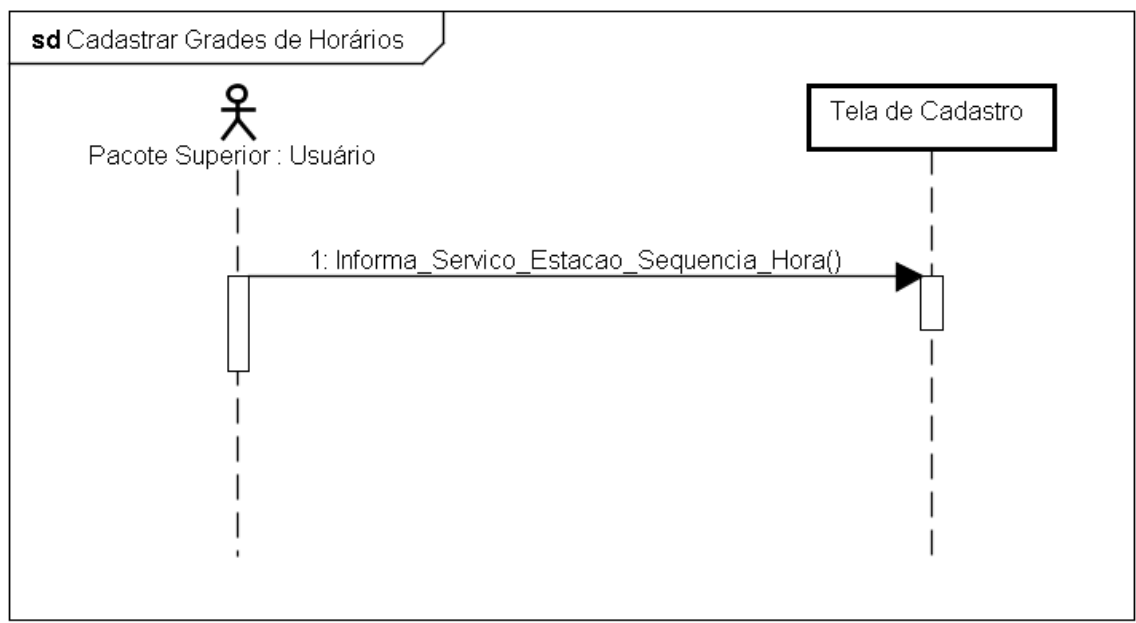

Figura 15 - Diagrama de seqüência Cadastrar Grades de Horários 


\subsubsection{Acompanhamento das posições dos ônibus}

Conforme citado anteriormente, a solução aqui proposta necessita da posição corrente dos ônibus que é fornecida via receptores GPS. Dados de identificação do receptor GPS (que identifica o ônibus), data, hora e posição espacial (geográfica) são utilizados para que o sistema localize o ônibus ao longo das rotas monitoradas, e com base nas demais informações as inconformidades possam ser identificadas.

\section{Diagrama de Caso de Uso}

Segue abaixo (Figura 16) o diagrama de caso de uso para armazenar dados posicionais do ônibus:

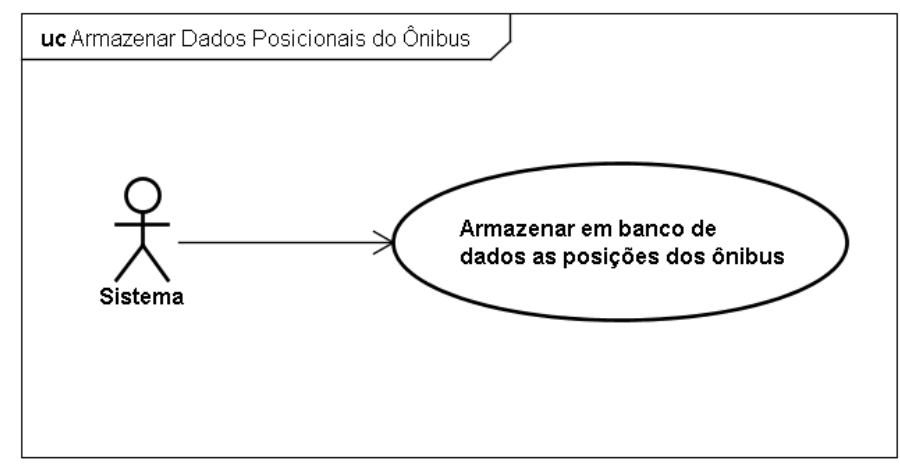

Figura 16 - Diagrama de caso de uso Armazenar Dados Posicionais do Ônibus

\section{Diagrama de Seqüência}

Segue abaixo (Figura 17) o diagrama de seqüência para armazenar dados posicionais do ônibus:

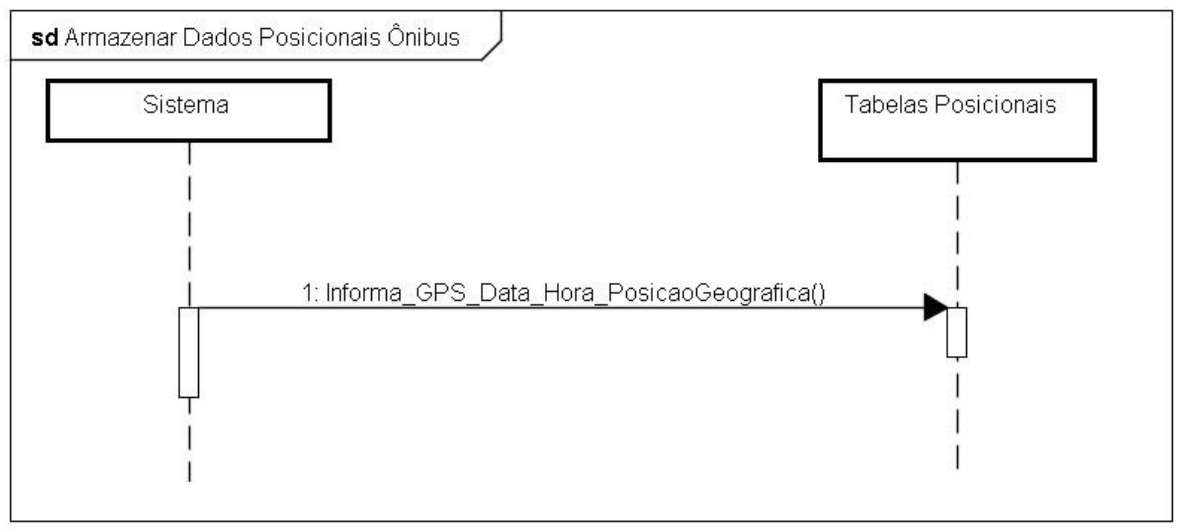

Figura 17 - Diagrama de seqüência Armazenar Dados Posicionais do Ônibus 


\subsubsection{Verificações de Inconformidades (por estação)}

A cada intervalo de tempo cadastrado (ITV) o sistema compara os dados cadastrados nas tabelas de grades de horário (para cada estação) com os dados armazenados das posições correntes de cada ônibus. Então, baseado nas outras variáveis cadastradas no próprio sistema (ITPO, VTAT e VTAD) o sistema é capaz de identificar se há ônibus atrasado ou adiantado.

\section{Diagrama de Caso de Uso}

Segue abaixo (Figura 18) o diagrama de caso de uso para verificação de inconformidades:

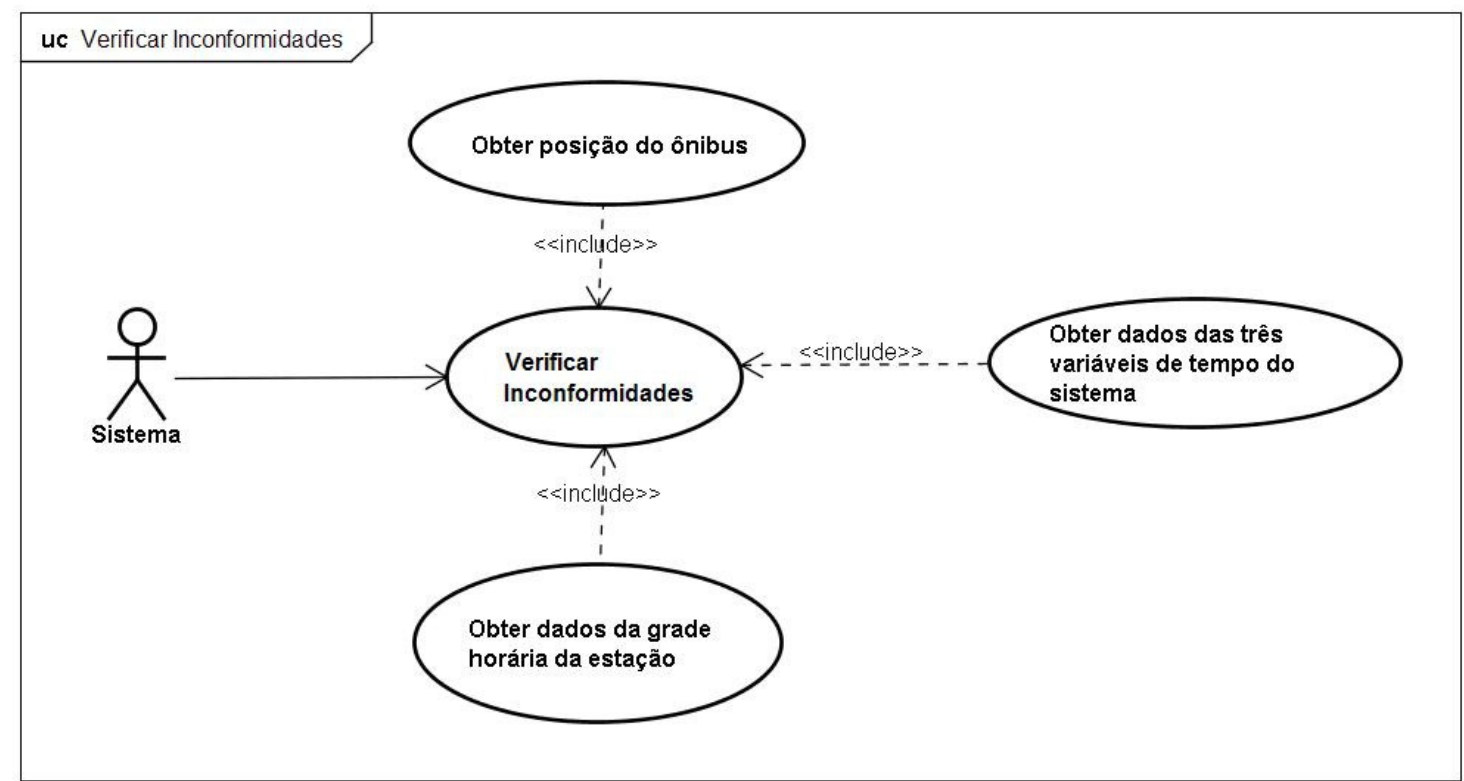

Figura 18 - Diagrama de caso de uso Verificar Inconformidades

No diagrama apresentado na Figura 18 pode-se observar o ator sistema no caso de uso de verificação de inconformidades. A partir dos dados da grade de horários (elipse inferior do diagrama), o sistema identifica quais ônibus deveriam estar em quais estações em quanto tempo. Então, o sistema baseia-se nas posições dos ônibus (elipse superior do diagrama) e efetua cálculos baseados em variáveis previamente cadastradas (elipse à direita no diagrama) para inferir se os ônibus irão chegar nas estações atrasados ou adiantados. E finalmente, as intervenções são executadas conforme algoritmos apresentados no Capítulo 7 desta dissertação. 


\section{Diagrama de Seqüência}

Segue abaixo (Figura 19) o diagrama de seqüência para verificação de inconformidades:

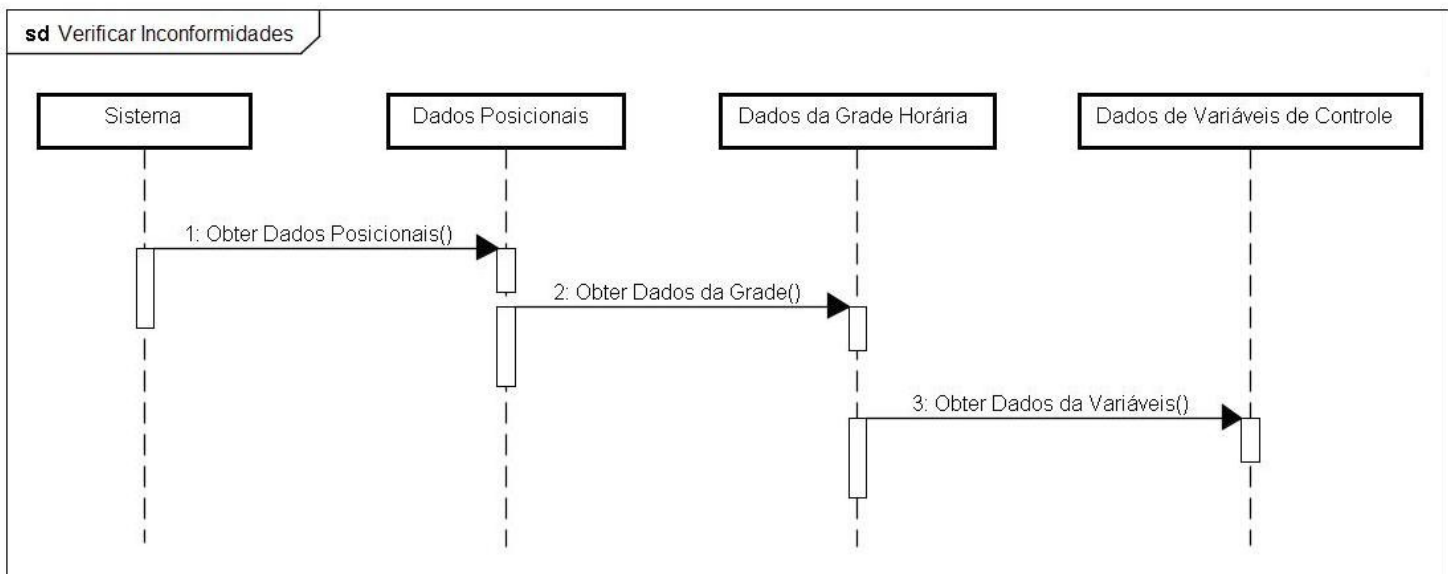

Figura 19 - Diagrama de caso de uso Verificar Atrasos

\subsubsection{Sistema solicita uma intervenção tipo StandBy (Ônibus Extra)}

Quando for identificado um grande atraso em determinado serviço, se solicita que um ônibus que estava em standby (ônibus "reserva" pronto para entrar em serviço) passe a cumprir o serviço. E se solicita que o ônibus que estava atrasado saia de serviço no final da linha.

Um mesmo serviço pode contar com mais de um ponto estratégico onde haja ônibus em standby prontos para entrar em serviço. Quando o sistema optar pela intervenção de ônibus extra, uma boa prática seria que o ônibus adicional entrasse em serviço já cumprindo a grade de horário pré-estabelecida. Esta abordagem corrigiria a inconformidade do ponto de entrada do ônibus extra adiante. Para tanto, a metodologia utilizada para solicitar que um ônibus entre ou saia de serviço é composto por três parâmetros:

1. O primeiro: identificador de qual linha (serviço) se trata a solicitação;

2. O segundo: identificador de qual estação se refere à ação; 
3. O terceiro: identificador do tipo da ação: entrar ou sair de serviço (pois a metodologia será utilizada tanto para solicitar que um ônibus entre em serviço, quanto para solicitar que o atrasado saia de serviço).

\section{Diagrama de Caso de Uso}

Segue abaixo (Figura 20) o diagrama de caso de uso para intervenção tipo Ônibus Extra (Standby):

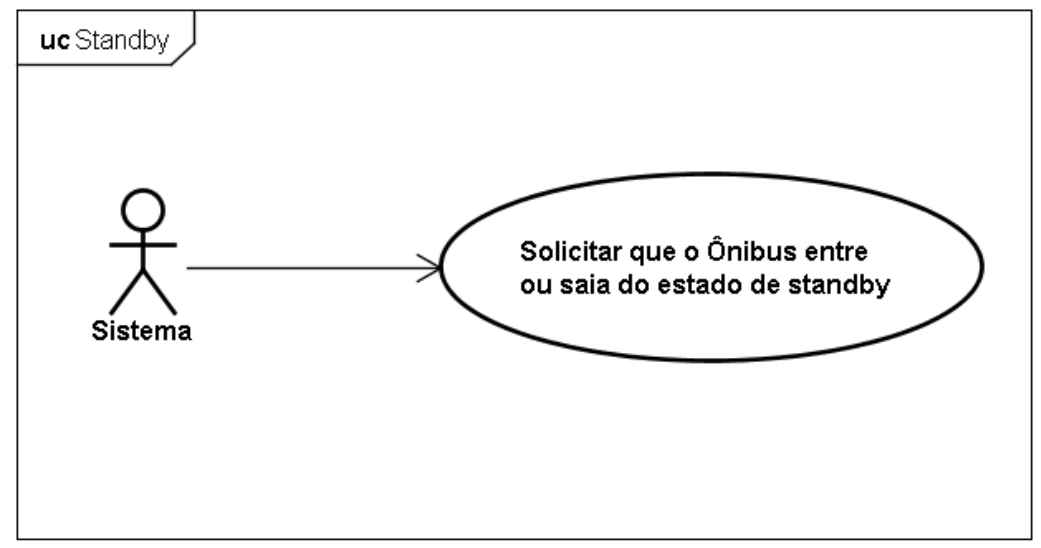

Figura 20 - Diagrama de caso de uso Intervenção tipo Standby

\section{Diagrama de Seqüência}

Segue abaixo (Figura 21) o diagrama de seqüência para intervenção tipo Ônibus Extra (Standby):

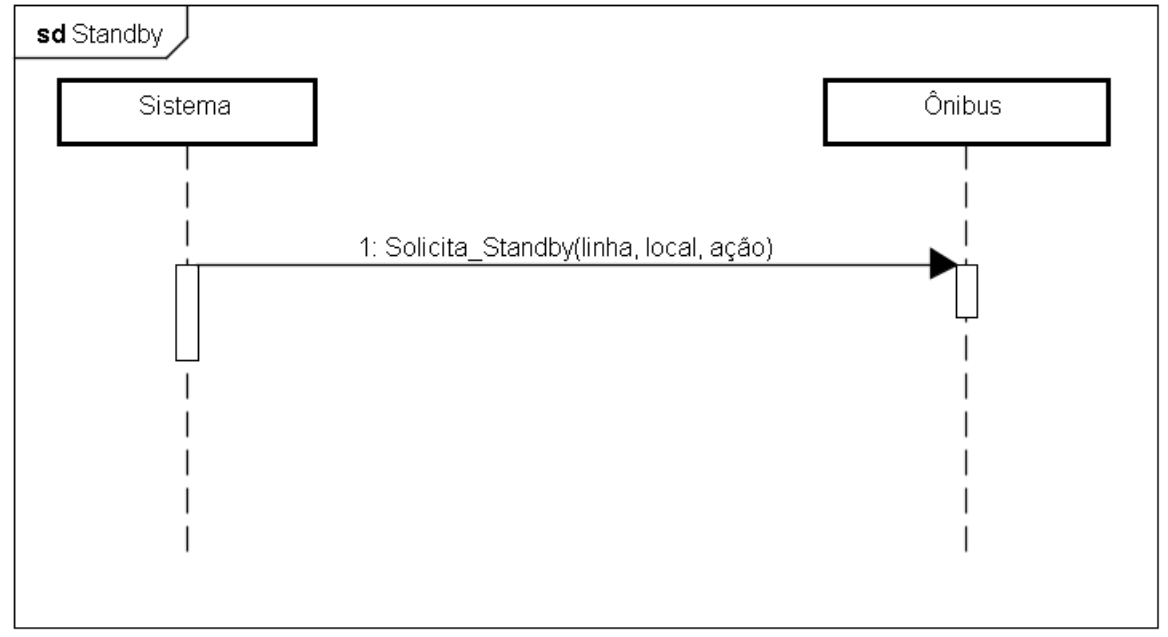

Figura 21- Diagrama de seqüência de Intervenção tipo Standby 


\subsubsection{Sistema solicita ao veículo que diminua a velocidade}

Em caso do ônibus estar adiantado, o sistema pode solicitar ao motorista que diminua a velocidade. A metodologia utilizada possui um argumento que informa sua defasagem de tempo.

\section{Diagrama de Caso de Uso}

Segue abaixo (Figura 22) o diagrama de caso de uso para intervenção tipo Diminuir Velocidade:

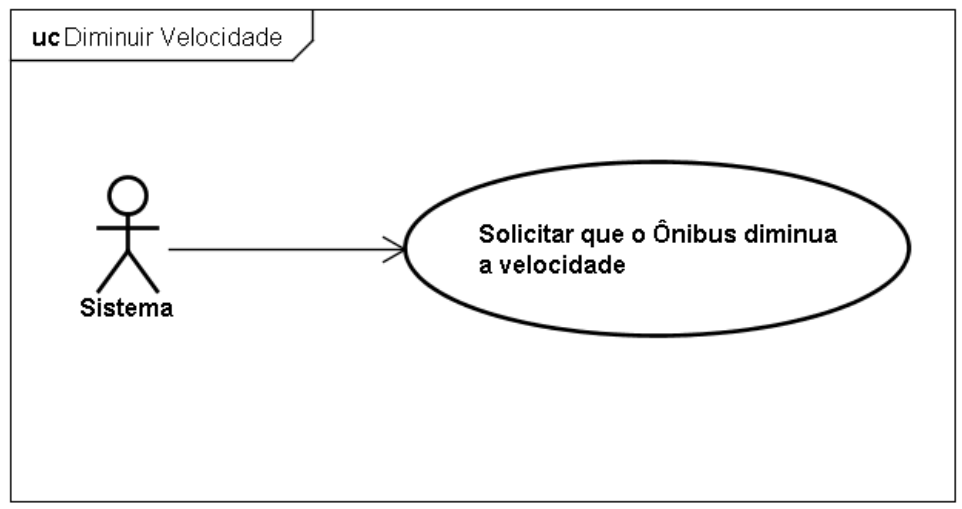

Figura 22 - Diagrama de caso de uso para Intervenção Diminuir Velocidade

\section{Diagrama de Seqüência}

Segue abaixo (Figura 23) o diagrama de seqüência para intervenção tipo Diminuir Velocidade:

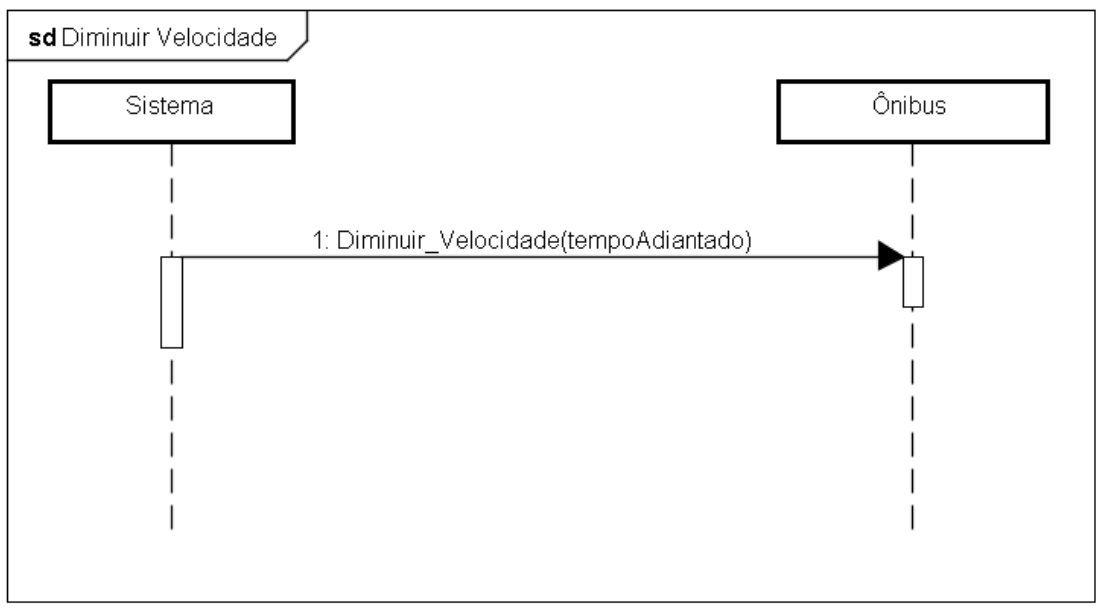

Figura 23 - Diagrama de seqüência de Intervenção Diminuir Velocidade 


\subsubsection{Sistema solicita ao veículo que espere no buffer ou na doca}

Para casos de ônibus adiantado, o sistema pode intervir solicitando que o ônibus espere na doca ou buffer. A metodologia utilizada possui um argumento que informa quanto tempo adiantado ele está.

\section{Diagrama de Caso de Uso}

Segue abaixo (Figura 24) o diagrama de caso de uso para intervenção tipo Esperar na Doca ou Buffer:

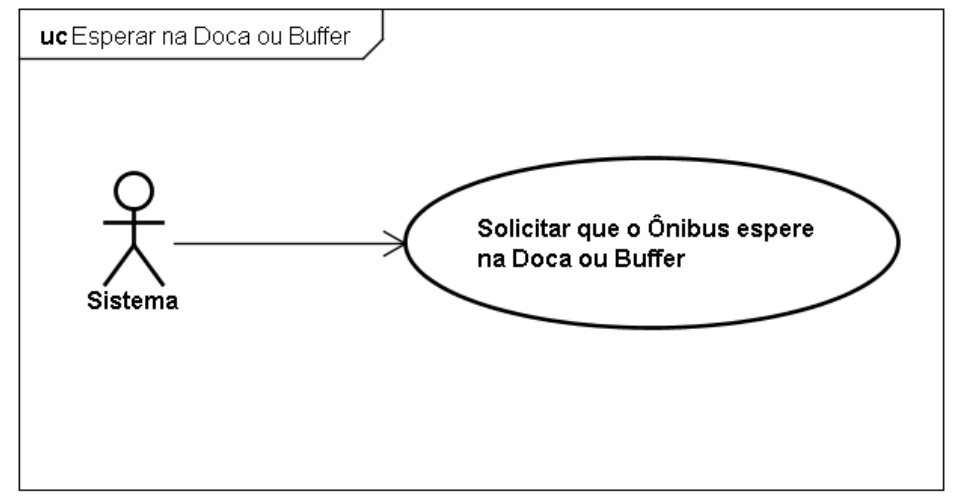

Figura 24 - Diagrama de caso de uso Intervenção Esperar na Doca ou Buffer

\section{Diagrama de Seqüência}

Segue abaixo (Figura 25) o diagrama de seqüência para intervenção Esperar na Doca ou Buffer:

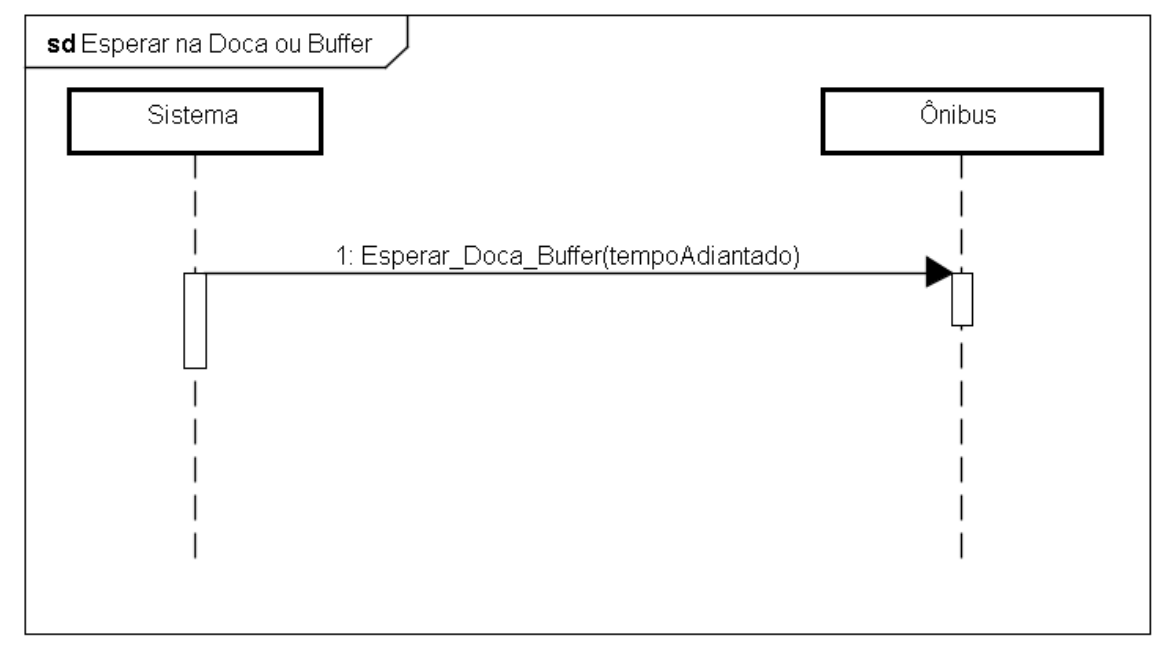

Figura 25 - Diagrama de seqüência de Intervenção Esperar na Doca ou Buffer 


\subsubsection{Sistema solicita um Bypass (não parar na próxima estação)}

Um bypass é a operação que faz com que o ônibus não pare na próxima estação. Este comando somente é atendido quando não houver uma solicitação de parada por parte de passageiros. E quando atendido o bypass, se existirem painéis informativos (sobre o itinerário) no ônibus ou em estações, os mesmos deverão ser alterados de forma a atualizar as informações. Caso haja dispositivos sonoros com gravações informativas de itinerários, estes também deverão ser atualizados. A metodologia utilizada na solicitação do bypass possui um argumento que informa ao motorista quanto tempo atrasado ele está.

\section{Diagrama de Caso de Uso}

Segue abaixo (Figura 26) o diagrama de caso de uso para intervenção tipo Saltar Estação (Bypass):

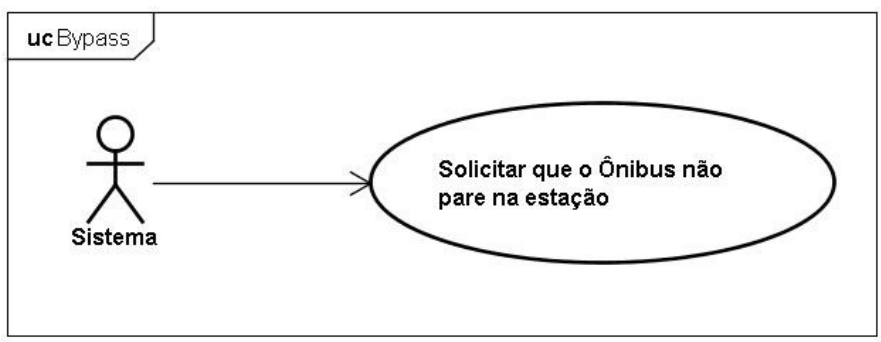

Figura 26 - Diagrama de caso de uso de Intervenção tipo Bypass

\section{Diagrama de Seqüência}

Segue abaixo (Figura 27) o diagrama de seqüência para intervenção tipo Saltar Estação (Bypass):

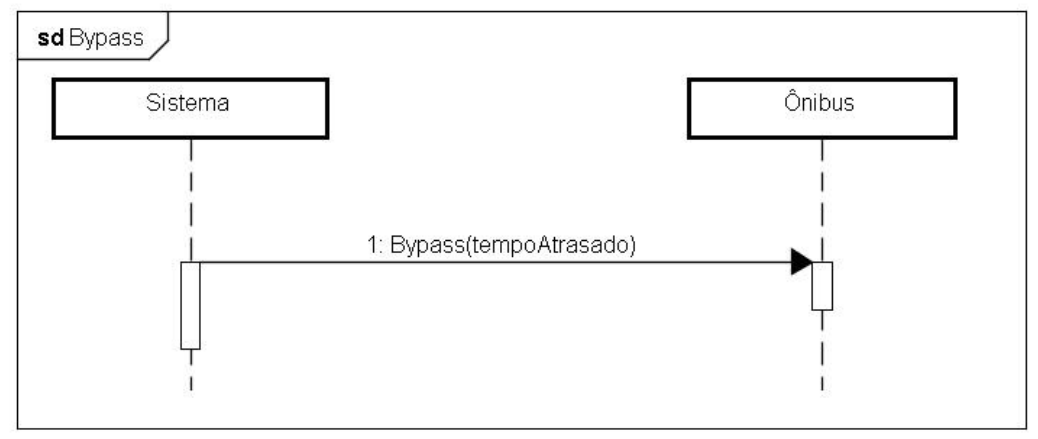

Figura 27 - Diagrama de seqüência de Intervenção tipo Bypass 


\subsubsection{Sistema envia uma ordem específica (por voz ou texto)}

Em casos específicos não contemplados pelo sistema, isto é, em caso de situações diversas e inesperadas, há a possibilidade do sistema enviar ao motorista ordens específicas não habituais. Esse tipo de abordagem não será freqüentemente utilizada, mas é útil e importante para enfrentar situações como vias interditadas por acidente ou enchente, por exemplo.

\section{Diagrama de Caso de Uso}

Segue abaixo (Figura 28) o diagrama de caso de uso para Envio de Mensagens do sistema para o ônibus:



Figura 28 - Diagrama de caso de uso Envio de Mensagem

\section{Diagrama de Seqüência}

Segue abaixo (Figura 29) o diagrama de seqüência para Envio de Mensagens do sistema para o ônibus:

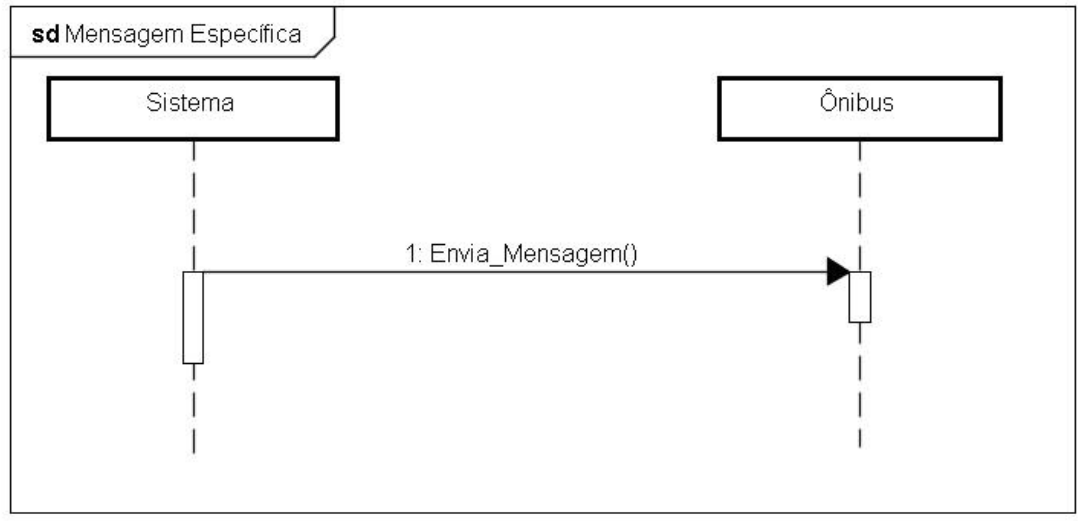

Figura 29 - Diagrama de seqüência Envio de Mensagem 
Um sistema de comunicação entre motorista e central de controle mais completo poderia ser implementado por exemplo, por meio de uso de rádio (é utilizado em cidades como Madrid e Londres). Dessa maneira o motorista poderia, além de receber informações instantaneamente, informar ou realizar solicitações para a central de controle. Evidentemente, por se tratar de um meio de comunicação similar ao telefone celular no tocante à dispersão causada ao motorista ao utilizar essa forma de comunicação, esse dispositivo deveria ser utilizado apenas em situações adversas, como citado anteriormente.

\subsubsection{Diagramas de Classe}

Tiago (2010) cita que um Diagrama de Classe contém as classes que caracterizam os objetos de um sistema. As classes são extraídas a partir da análise dos diagramas de casos de uso, e representam os componentes de interação do sistema e como eles se relacionam. Uma classe é representada por um retângulo sólido composto de três partes utilizadas para:

- Nome da classe;

- Atributos da classe (suas características);

- Declaração das operações definidas para a classe.

\subsubsection{Intervenções - solicitações do sistema}

A representação por diagrama de classe das intervenções (ocorrências) definidas pelo sistema abrange os ônibus, estações e as intervenções propriamente ditas, sendo estas últimas direcionadas para o ônibus e com possível repercussão nos painéis das estações (alterando a seqüência de ônibus que atenderá a estação) e nos painéis internos dos ônibus (alterando a próxima parada - estação). Segue abaixo (Figura 30) o diagrama de classe Ocorrência: 


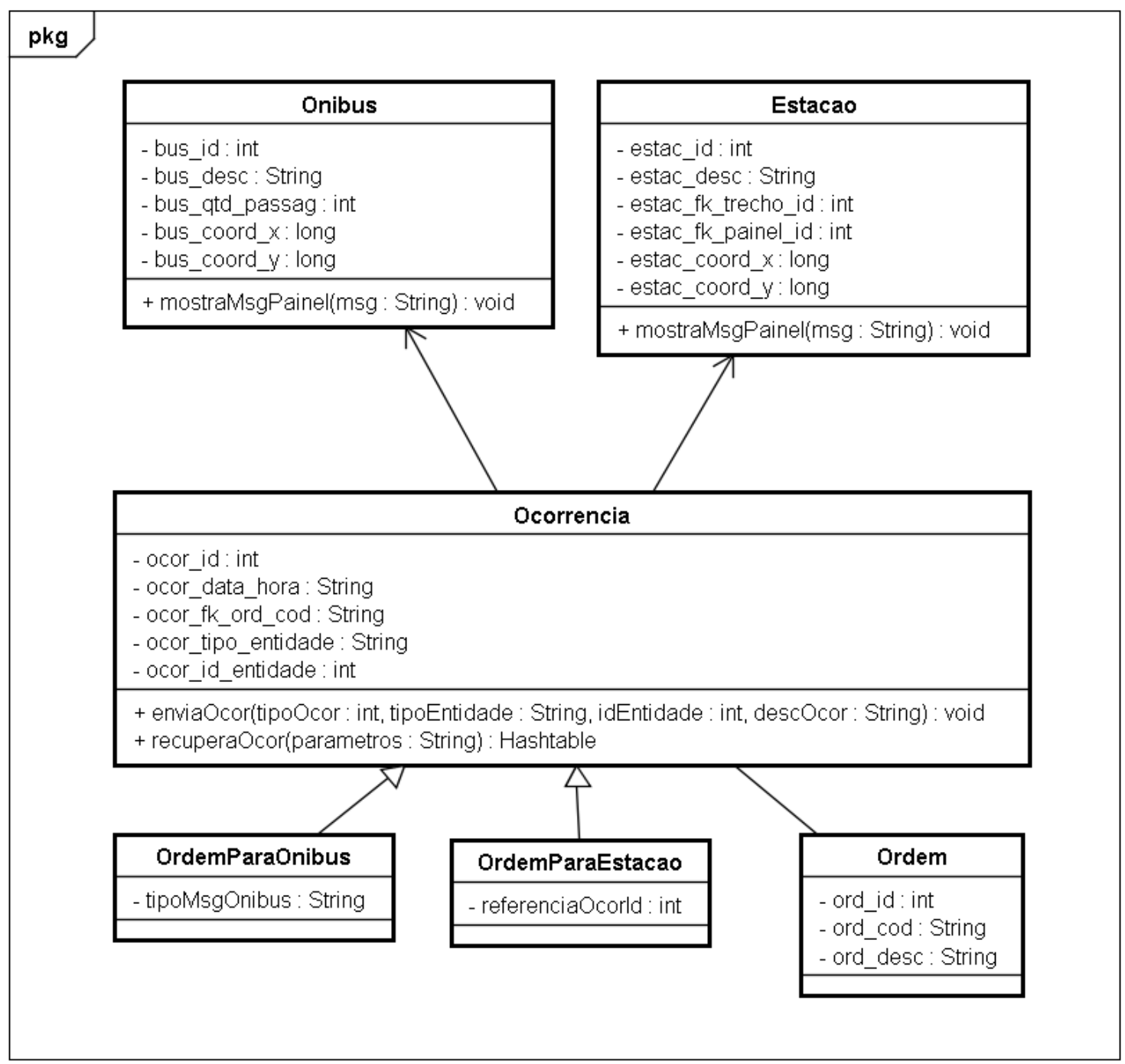

Figura 30 - Diagrama de classe Ocorrência

\subsubsection{Serviços}

Os serviços são, basicamente, os ônibus visitando as estações conforme previsto nas grades de horário. Assim, o diagrama de classe que represente este cenário envolve diversas entidades, apresentadas abaixo (Figura 31): 


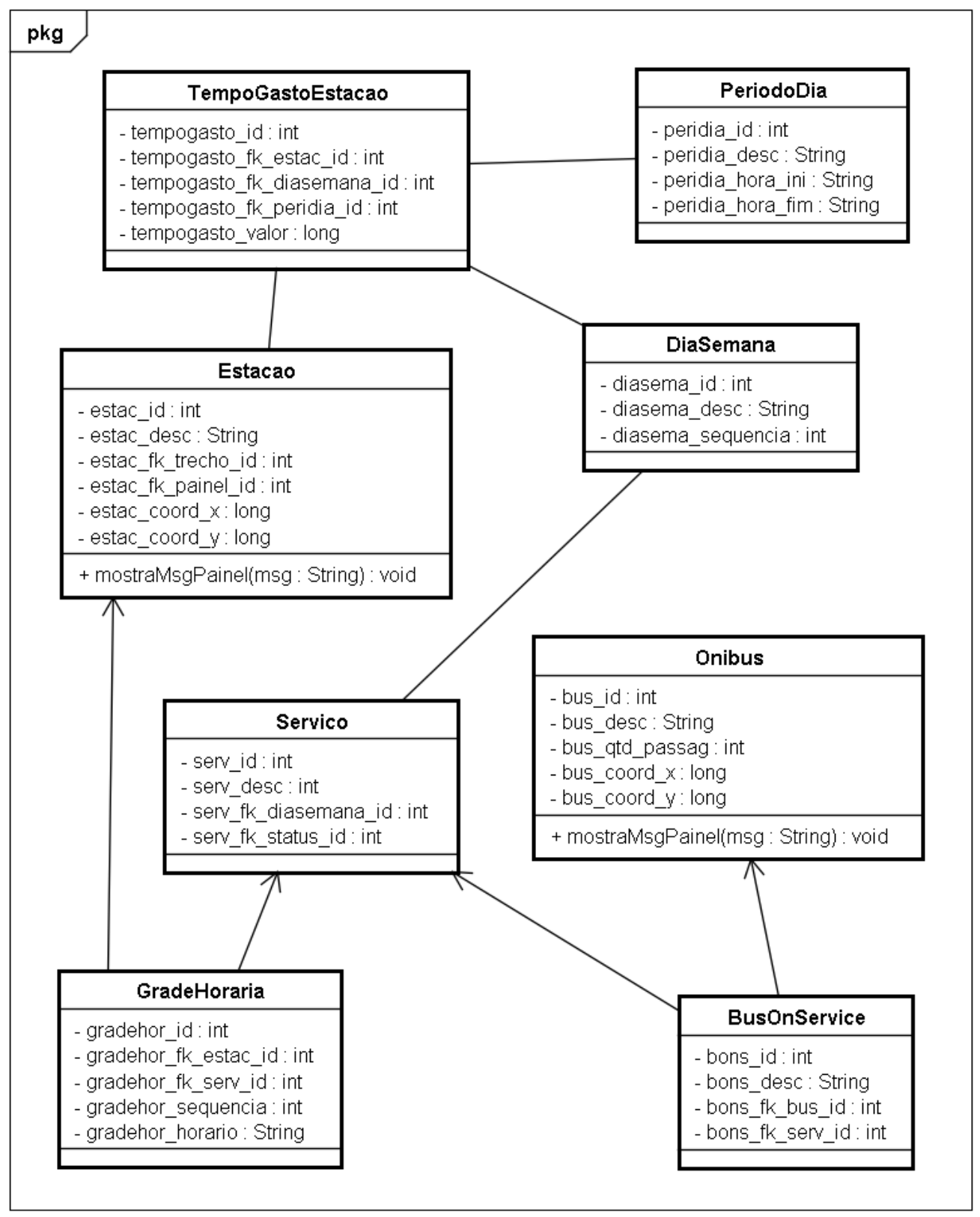

Figura 31 - Diagrama de classe Serviço

\subsubsection{Estações}

As médias dos valores de tempos de embarque e desembarque de passageiros em cada estação são armazenados de forma a ser possível inferir mais precisamente quanto tempo levará esse procedimento em diferentes horários de diferentes dias (como em feriados, por exemplo). Além disso, a estação está vinculada a um determinado trecho que possui valores de comprimento e velocidade média, o que é 
suficiente para se calcular o tempo gasto em média para percorrer o trecho. Outras características das estações são as quantidades de buffers (que pode ser zero) e docas. Segue abaixo (Figura 32) o diagrama de classe Estação:

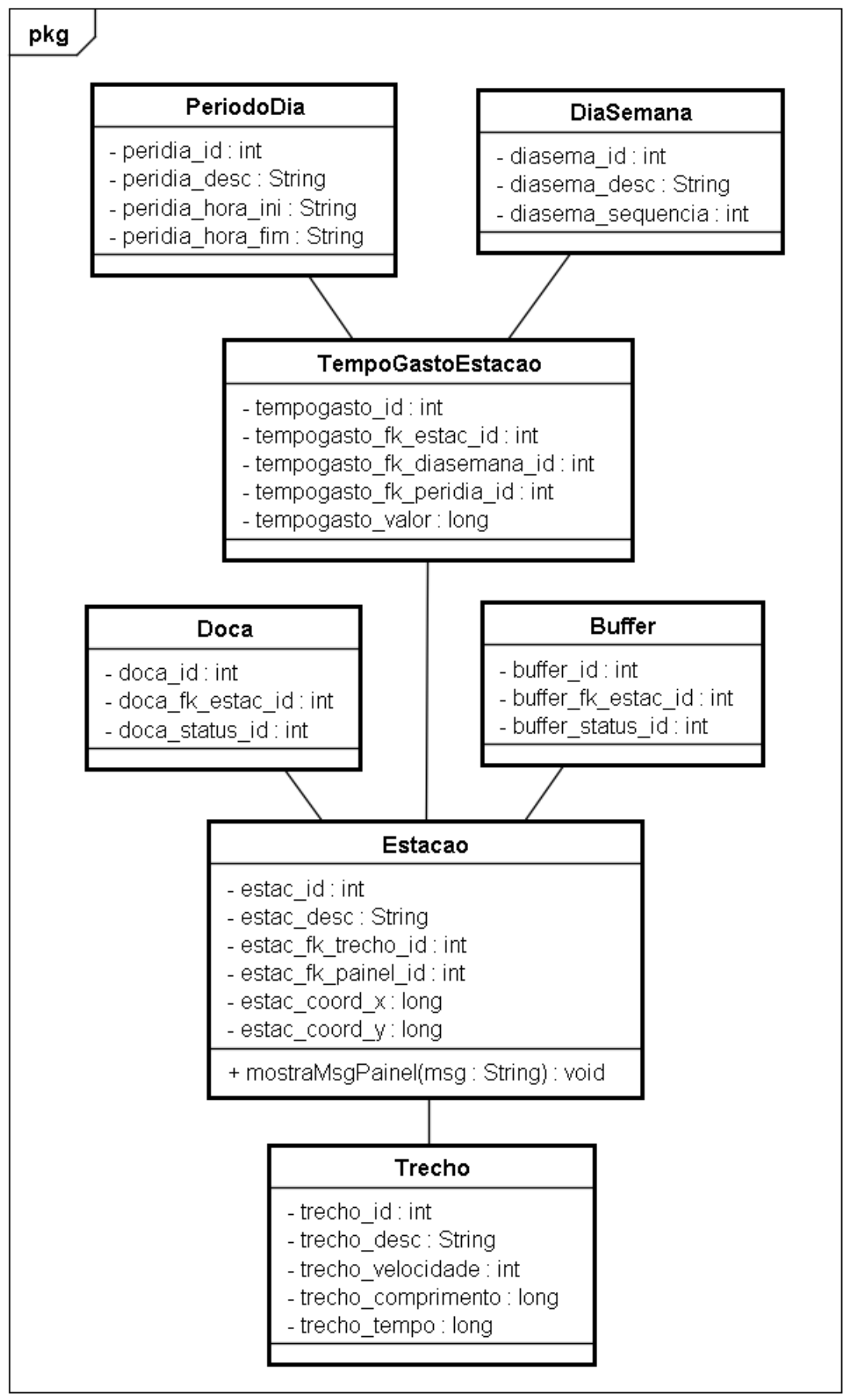

Figura 32 - Diagrama de classe Estação 


\subsubsection{MER - Modelo Entidade Relacionamento do Banco de Dados}

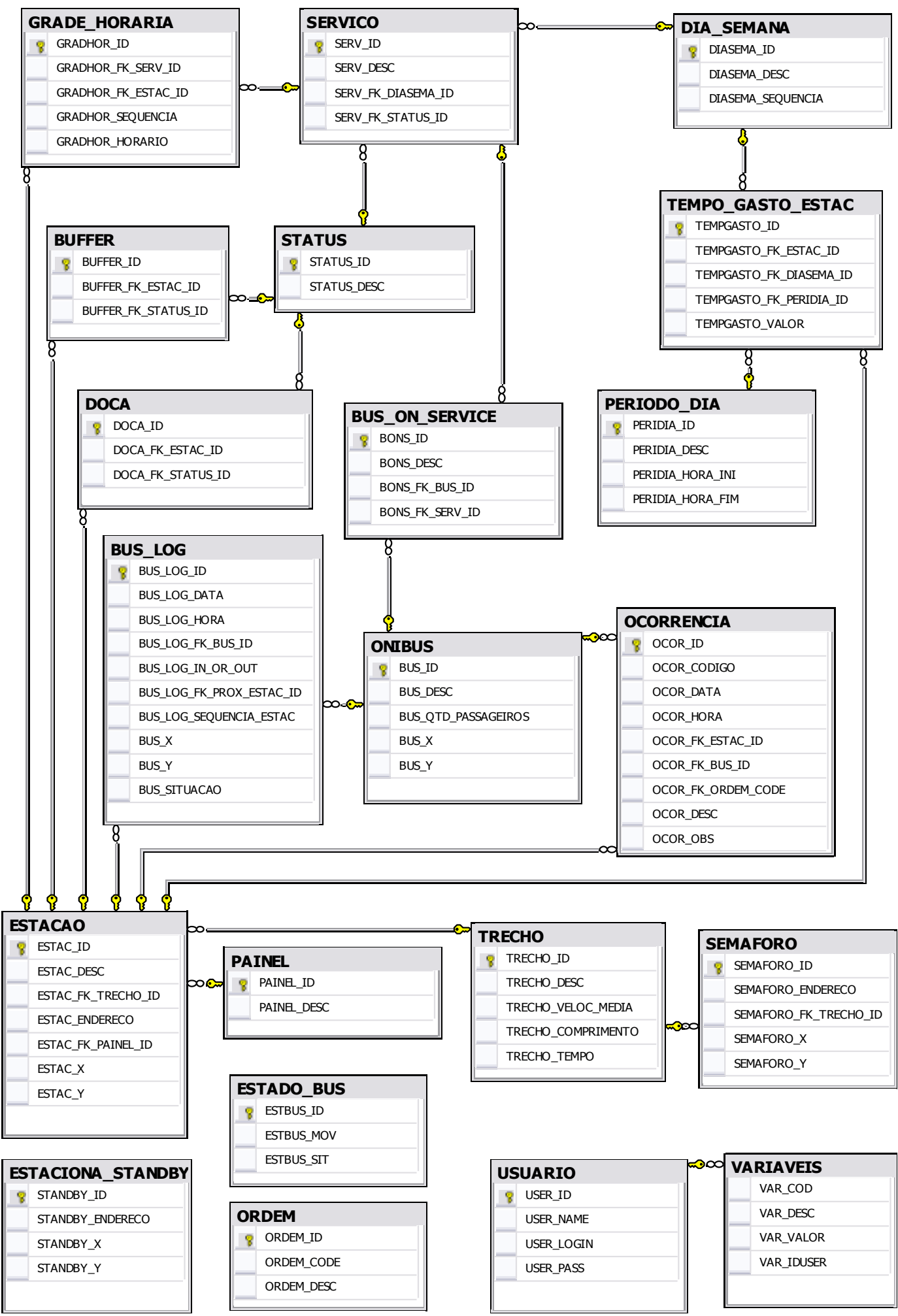

Figura 33 - MER do banco de dados 


\subsection{Algoritmos Utilizados}

As intervenções executadas pelo sistema dependem do cumprimento das metas de horários que são estabelecidas pelas grades horárias. Se cada ônibus estiver cumprindo devidamente sua respectiva grade horária de serviço, o sistema nada tem a fazer. Mas este seria um mundo ideal, que está longe do real em diversas cidades, principalmente nas grandes, onde o tráfego intenso e os congestionamentos já fazem parte do dia-a-dia das pessoas.

O sistema proposto é dotado de lógica para agir nas situações adversas encontradas nos serviços dos ônibus. Basicamente, o sistema monitora a frota verificando a situação dos ônibus (atrasado, adiantado ou conforme) em relação às estações, e toma decisões de intervenção caso considere necessário. Essas verificações são executadas constantemente para identificar as possíveis inconformidades. Caso seja identificada uma inconformidade, o sistema avalia as possibilidades de intervenção e decide o que fazer dependendo se o ônibus está atrasado ou adiantado.

\subsubsection{Identificação dos ônibus em inconformidade}

Como o sistema possui (1) Grades de horários de serviços para as linhas em diferentes dias da semana; (2) Identificação de qual ônibus está cumprindo qual serviço; (3) Posicionamento instantâneo do ônibus; (4) Malha viária com informações de kilometragem e velocidades médias dos trechos; (5) Variáveis passíveis de configuração direta pelo usuário do sistema (ITV, ITPO, VTAT e VTAD, é possível identificar se um ônibus está adiantado ou atrasado. Segue abaixo (Figura 34) o fluxograma do algoritmo, e mais abaixo os passos básicos do mesmo: 


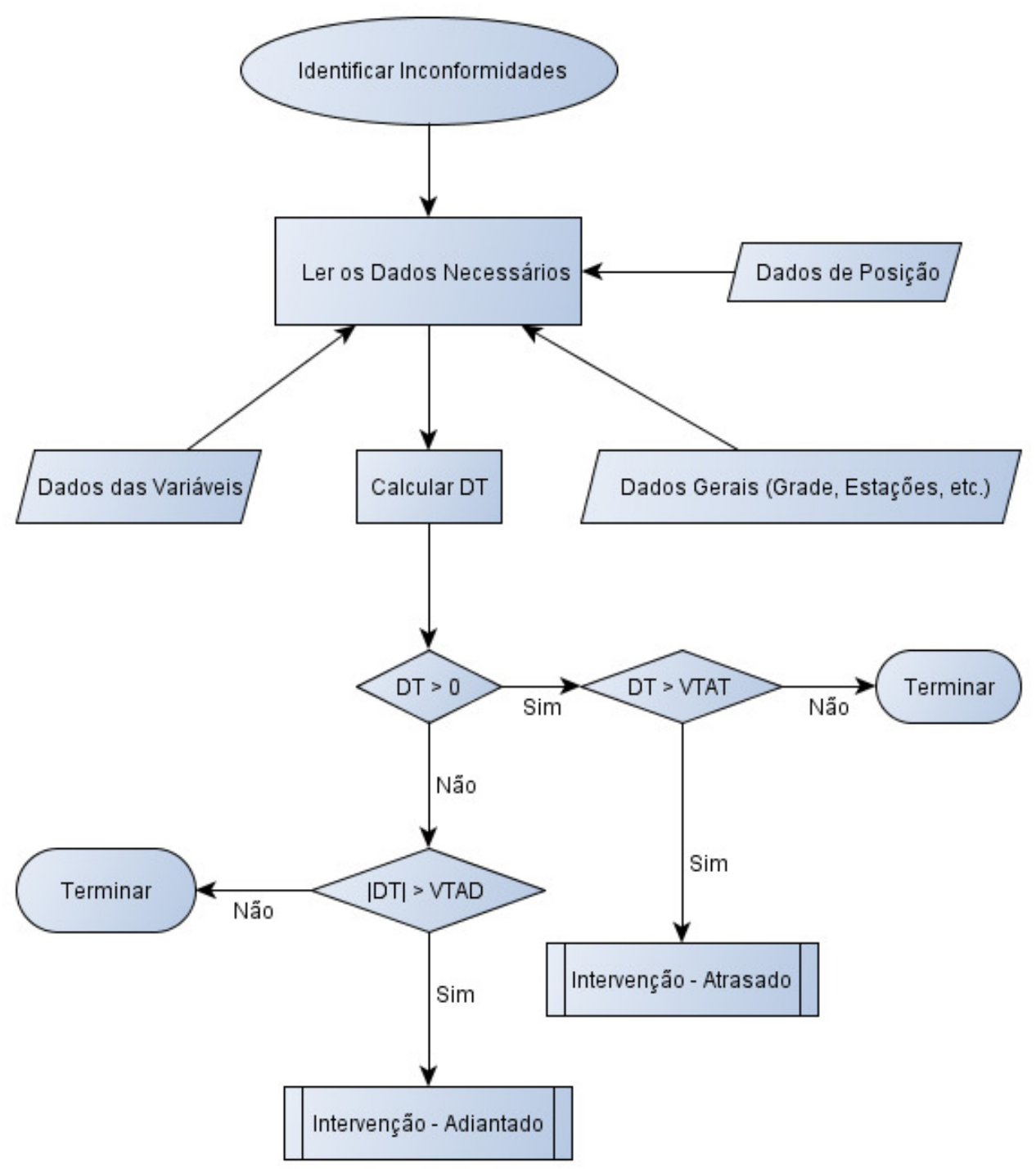

Figura 34 - Fluxograma de Identificação de Inconformidades

Passo 1: A cada ITV minutos, para todas as estações fazer:

Passo 2: Nos próximos ITPO minutos, obter a lista dos ônibus que deveriam estar na estação, e para cada um fazer:

Passo 3: Considerando [TG] como o tempo que o ônibus deveria levar até chegar à estação (baseado na grade horária), [TO] como o tempo que o ônibus levará até chegar à estação (baseado na distância que ele se encontra da estação), calcular DT, que é a diferença entre TO e TG (DT = TO - TG). 
Passo 4-1: Se [DT] for positivo e maior que VTAT minutos, o ônibus será considerado ATRASADO (AT).

Passo 4-2: Se [DT] for negativo e seu valor absoluto for maior que VTAD minutos, o ônibus será considerado ADIANTADO (AD). Neste caso será considerada a distância real do ônibus até a estação (DROE) para escolha da intervenção mais adequada.

Passo 5: Executar o algoritmo de possibilidade de intervenção (abaixo), informando AT ou AD e também o |DT| calculado. E para o caso do passo 4-2, informar também o DROE.

\subsubsection{Escolha de intervenção}

Baseado em:

- Informações resultantes do algoritmo de identificação de inconformidades dos ônibus apresentado acima (AT, AD, |DT| e DROE);

- Informações armazenadas no banco de dados do sistema (como docas e buffers de estações, etc.);

- Variáveis passíveis de configuração direta pelo usuário do sistema:

- VLOE: valor limite para adotar a intervenção de ônibus extra.

○ VDOE: valor limite da distância do ônibus até a estação.

Uma das seguintes intervenções será selecionada:

- AD_PE: adiantar - pular estação.

- AD_OE: adiantar - solicitar ônibus extra.

- AT_DV: atrasar - diminuir velocidade.

- AT_EB: atrasar - esperar no buffer. 
- AT_ED: atrasar - esperar na doca.

Segue abaixo (Figura 35) o fluxograma do algoritmo, e mais abaixo a lógica utilizada para selecionar a intervenção:

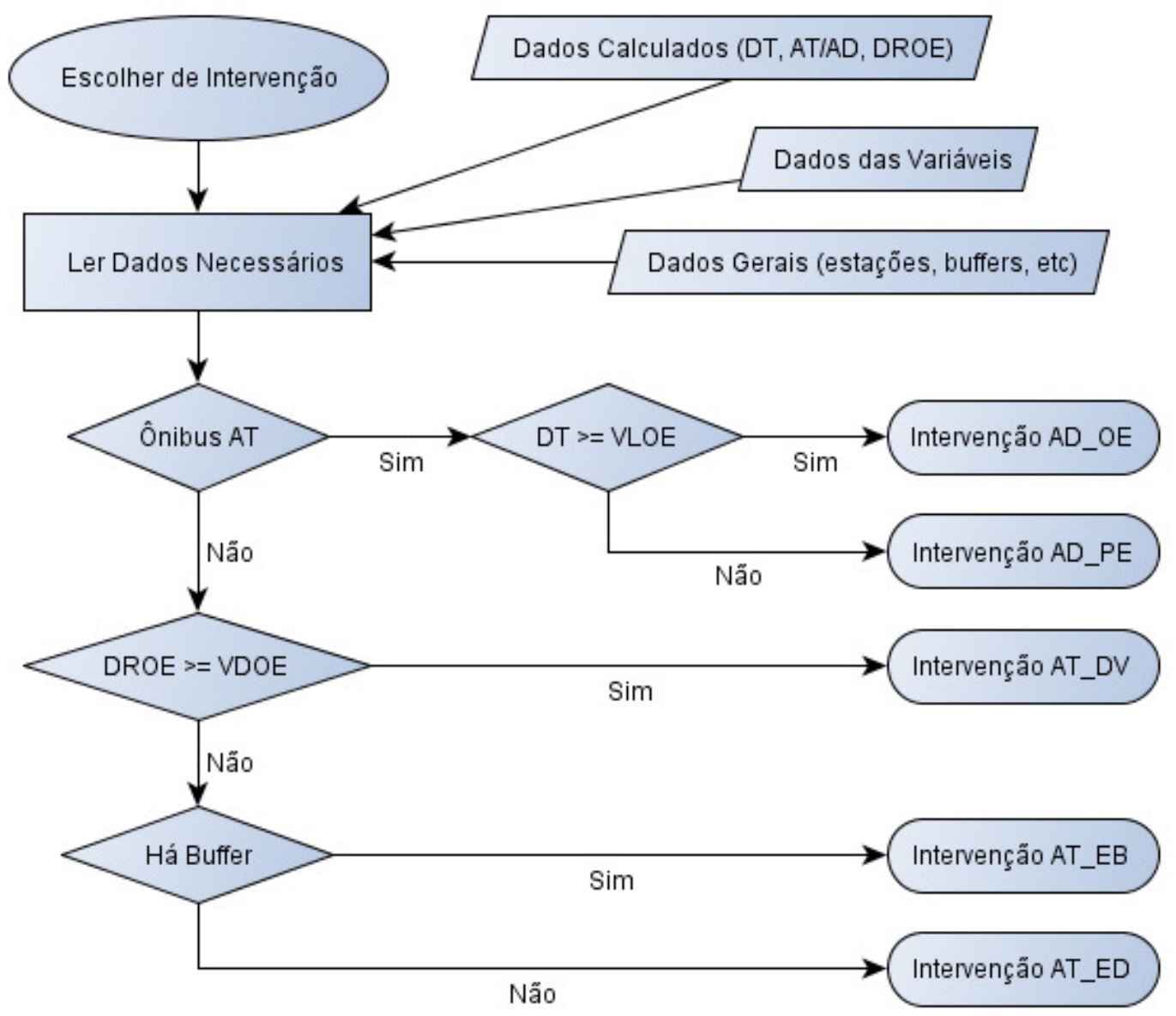

Figura 35 - Fluxograma de Seleção da Intervenção

Intervenção 1: Se ônibus está atrasado (AT) e o valor do atraso for menor que o valor limite para adotar a intervenção de ônibus extra (DT < VLOE), então selecionar intervenção não parar na próxima estação (AD_PE).

Intervenção 2: Se ônibus está atrasado (AT) e o valor do atraso for maior ou igual ao valor limite para adotar a intervenção de ônibus extra (DT >= VLOE), então selecionar intervenção de ônibus extra (AD_OE). 
Intervenção 3: Se ônibus está adiantado (AD) e a distância real do ônibus até a estação for maior ou igual ao valor limite da distância do ônibus até a estação (DROE >= VDOE), então selecionar intervenção diminuir a velocidade (AT_DV).

Intervenção 4: Se ônibus está adiantado $(A D)$ e a distância real do ônibus até a estação for menor que o valor limite da distância do ônibus até a estação (DROE < VDOE) e há buffer na estação, então selecionar intervenção esperar no buffer (AT_EB).

Intervenção 5: Se ônibus está adiantado (AD) e a distância real do ônibus até a estação for menor que o valor limite da distância do ônibus até a estação (DROE < VDOE) e não há buffer na estação, então selecionar intervenção esperar na doca (AT_ED). 


\section{SIMULAÇÕES: CASO DE ESTUDO EM SÃO PAULO}

\subsection{Dados Utilizados}

Para realizar a simulação da deteç̧ão de inconformidades e intervenção, utilizou-se um trecho real da Avenida Santo Amaro (corredor de ônibus Santo Amaro - Nove de Julho) do município de São Paulo (trecho destacado em azul na Figura 36).

O mapa em escala 1:1.000.000 apresentado abaixo possui em cinza os limites de parte dos municípios do estado de São Paulo. Esses limites municipais foram obtidos em formato shapefile, diretamente no website do IBGE.

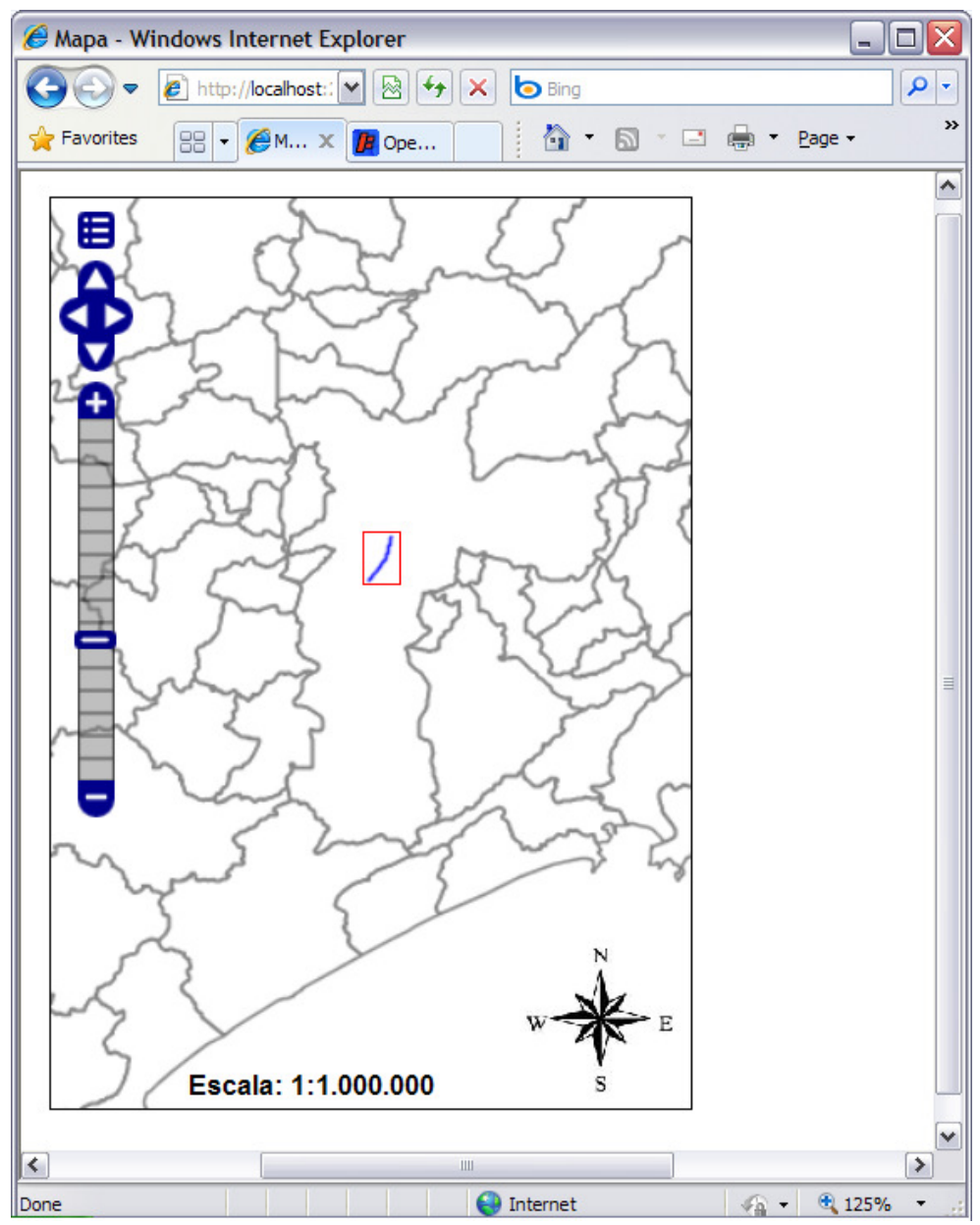

Figura 36 - São Paulo (ao centro) e outros municípios ao redor 
O Laboratório de Geoprocessamento do Departamento de Engenharia de Transportes da EPUSP disponibilizou, para fins de pesquisa, arquivos (em formato shapefile) contendo a rede viária do município de São Paulo. Desta densa rede, aproximadamente sete kilômetros da Avenida Santo Amaro foram utilizados para a simulação de identificação de inconformidade e tomada de decisão. O retângulo em vermelho na Figura 36 (acima) é apresentado no mapa abaixo de forma ampliada (escala 1:46.000):



Figura 37 - Destaque em azul de trecho da Av. Santo Amaro e estações 
O mapa da Figura 37 apresenta em cinza parte da rede viária na região sul do município de São Paulo bem como o trecho da Avenida Santo Amaro (linha azul), foco do estudo deste trabalho, com as estações de ônibus (pontos vermelhos) obtidas via imagens de satélite do programa Google Earth (data das imagens: 15/12/2008, acessado em 11/2009). Neste mapa se apresentam as 14 estações existentes no trecho em 15/12/2008. Mas apenas 8 estações foram utilizadas nas simulações do serviço a ser monitorado. Isto se deve ao fato de que no corredor estudado, nem todos os ônibus param em todas as estações, mesmo porque algumas se encontram muito próximas. A escolha das 8 estações, dentre as 14 obtidas por imagens de satélite, foi realizada manualmente (sem método científico ou trabalho de campo) levando-se em conta a distância entre as estações (dado baseado em BRT's de baixa demanda, como o de Ottawa [Canadá], por exemplo), ou seja, de forma que o serviço de ônibus analisado na simulação servisse estações com distâncias semelhantes, e com base no conhecimento de campo que nem todos os ônibus param em todas as estações.

Os mapas apresentados nas Figuras 36 e 37 foram obtidos através de requisições de serviços de mapas WMS (Web Map Services) através de um navegador de internet para o servidor de mapas GeoServer. Os respectivos serviços de mapa utilizados foram configurados para obter os mapas diretamente dos dados em modelo vetorial armazenados em tabelas espaciais no banco PostGIS. A carga de dados foi realizada utilizando-se os arquivos em formato shapefile, através de uma ferramenta específica de importação de dados chamada shp2sql. Essa ferramenta é do PostGIS e gera um arquivo com scripts de criação de tabelas (dentre outros elementos de banco de dados) e inserção dos dados que estão nos arquivos shapefile. Então, esse arquivo pode ser executado no PostGIS para se obter a informação do shapefile armazenada no banco de dados espacial. 


\subsection{Navegação no Sistema}

Conforme apresentado anteriormente, a tela de Menu do sistema contém quinze botões a serem utilizados para cadastros diversos (ônibus, estações, etc.). Além destes, há outros quatro botões para funções específicas. São eles:

1. Botão Mapa: apresenta uma tela do sistema com um mapa contendo os municípios brasileiros, a rede viária de São Paulo-SP, um trecho da Av. Santo Amaro em destaque, e estações de ônibus do trecho (Figura 37);

2. Botão Variáveis: apresenta uma tela do sistema (Figura 38) contendo seis campos para serem informados pelo usuário. Esses campos são utilizados para identificar inconformidades dos ônibus em relação às grades de horário e para tomar decisões de intervenção:

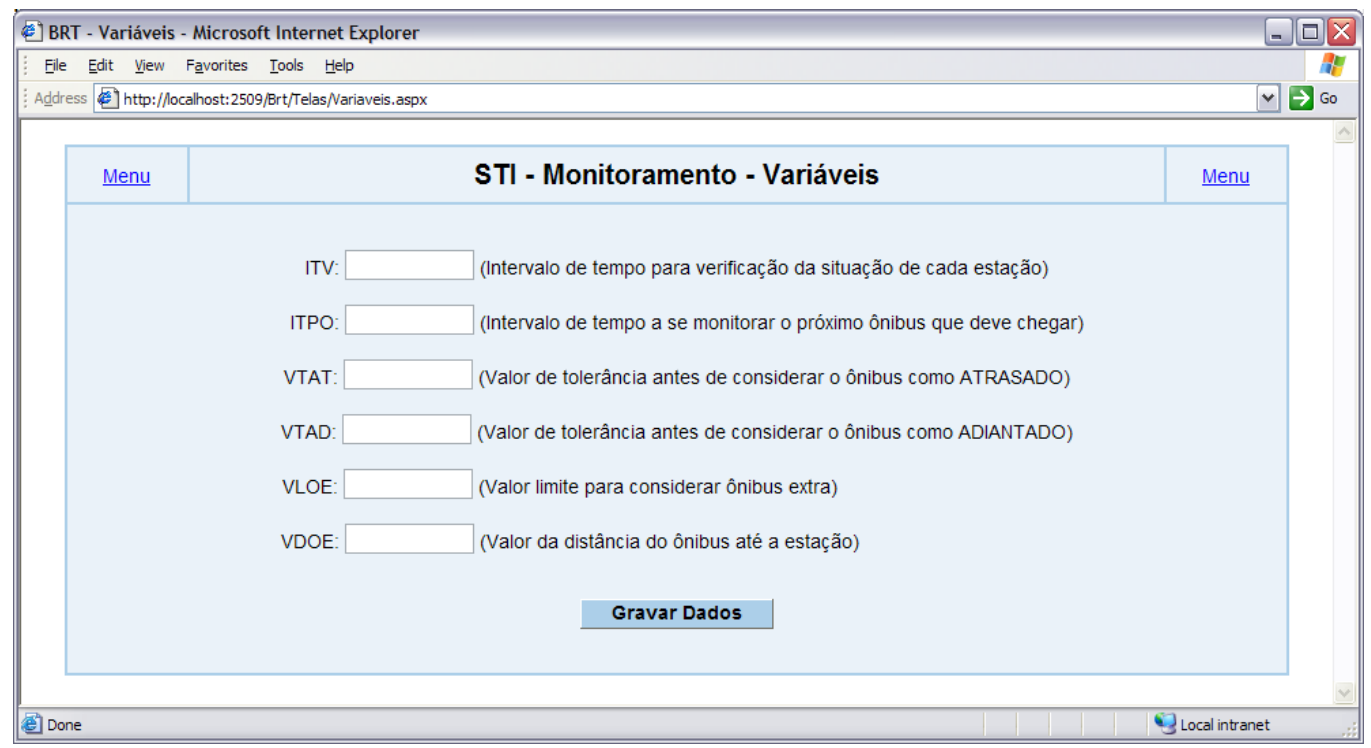

Figura 38 - Tela do sistema para cadastro de variáveis

3. Botão Ocorrências: apresenta uma tela do sistema (Figura 39) contendo as intervenções executadas pelo sistema. Dessa maneira são registradas data e hora da intervenção, em qual estação ocorreu, qual ônibus e qual a descrição da ocorrência que gerou a intervenção: 


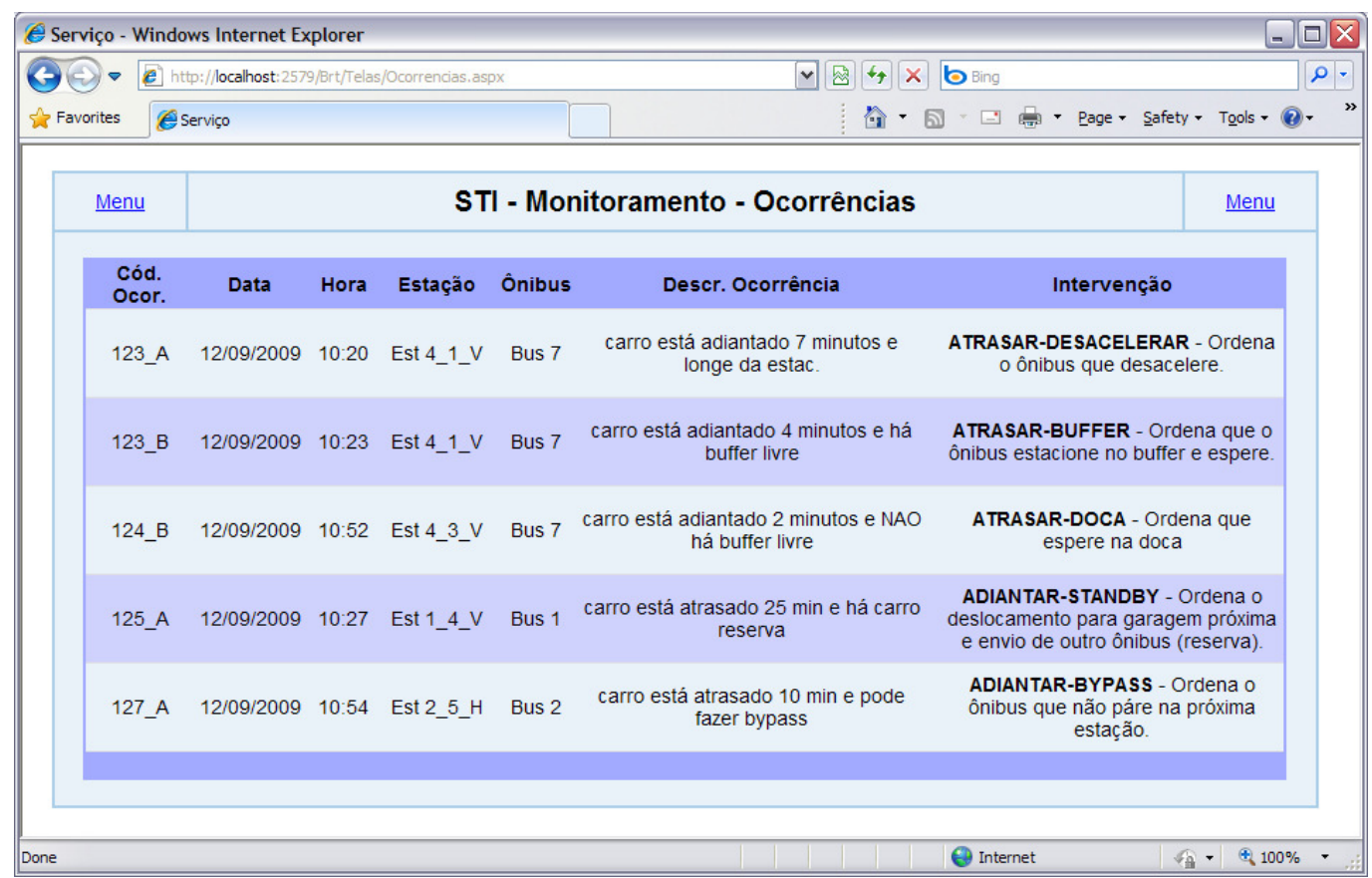

Figura 39 - Tela do sistema para apresentação das intervenções realizadas

4. Botão Unifilar: apresenta uma importante tela do sistema utilizada para verificar e comparar os comportamentos dos ônibus em diferentes situações. A tela (Figura 41) é composta por:

- Lista dos ônibus que podem ser visualizados;

- Dois diagramas unifilares do trecho em estudo;

- Três áreas indicando as posições dos ônibus em três diferentes situações:

I. Onde o ônibus deveria estar em determinado horário;

II. Onde o ônibus está (baseado nos dados do monitoramento da frota);

III. Onde o ônibus estaria em caso de intervenção do sistema. 


\subsection{Diagramas Unifilares - visualização de comportamentos}

Com o objetivo de apresentar as simulações dos ônibus monitorados, foi criada uma tela no sistema onde se encontra um diagrama unifilar (kilometrado) do trecho de estudo da Av. Santo Amaro com marcações temporais sobre ele. Neste trecho considerou-se a existência de oito estações (baseado nas imagens de satélite do Google Earth) de embarque/desembarque para um suposto serviço. E seguindo os parâmetros abaixo, citados pelo Manual de BRT (Brasil, 2007), calculou-se que o tempo total para um ônibus percorrer todo trecho de estudo (6883 metros) em situações ideais seria de aproximadamente 22 minutos. Parâmetros:

- Tempo morto (tempo de aceleração e frenagem na estação): 10 segundos;

- Tempo de parada para embarque/desembarque: 20 a 40 segundos;

- Velocidade média dos trechos: $25 \mathrm{~km} / \mathrm{h}$.

A Figura 40 apresenta as oito estações de ônibus utilizadas na simulação (representadas pelas letras do alfabeto de $\mathrm{A}$ até $\mathrm{H}$ ), cada uma delas localizada em determinada metragem do trecho unifilar iniciado em 0 (zero) metros.

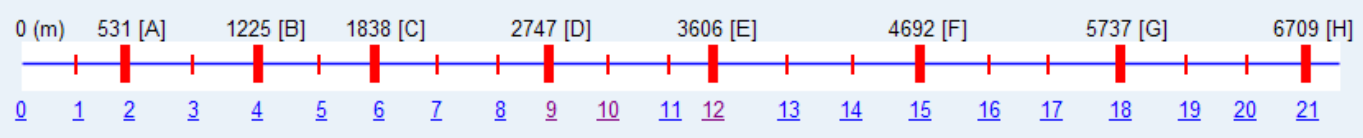

Figura 40 - Diagrama unifilar do trecho em estudo com as estações do serviço

Entre as estações há pontos de controle que se somados às 8 estações totalizam 21 pontos. Cada um desses 21 pontos são marcos espaciais e em minutos, ou seja, onde o ônibus deveria estar naquele minuto. Exemplo: para o serviço utilizado na simulação, no décimo segundo minuto o ônibus deveria estar na estação $E$ (ou seja, ter percorrido 3606 metros).

A Figura 41 apresenta a tela do sistema em um dado momento da simulação para o ônibus de nome Bus 1. Observa-se no canto superior esquerdo da tela, uma caixa de seleção (típica de sistemas de informação) onde são listados os ônibus em 
serviço. Abaixo da caixa de seleção está o diagrama unifilar com as metragens, tempos e indicações de estações, e mais abaixo o mesmo diagrama mas apenas com a rota de 6883 metros (linha azul) e as 8 estações (pontos vermelhos):

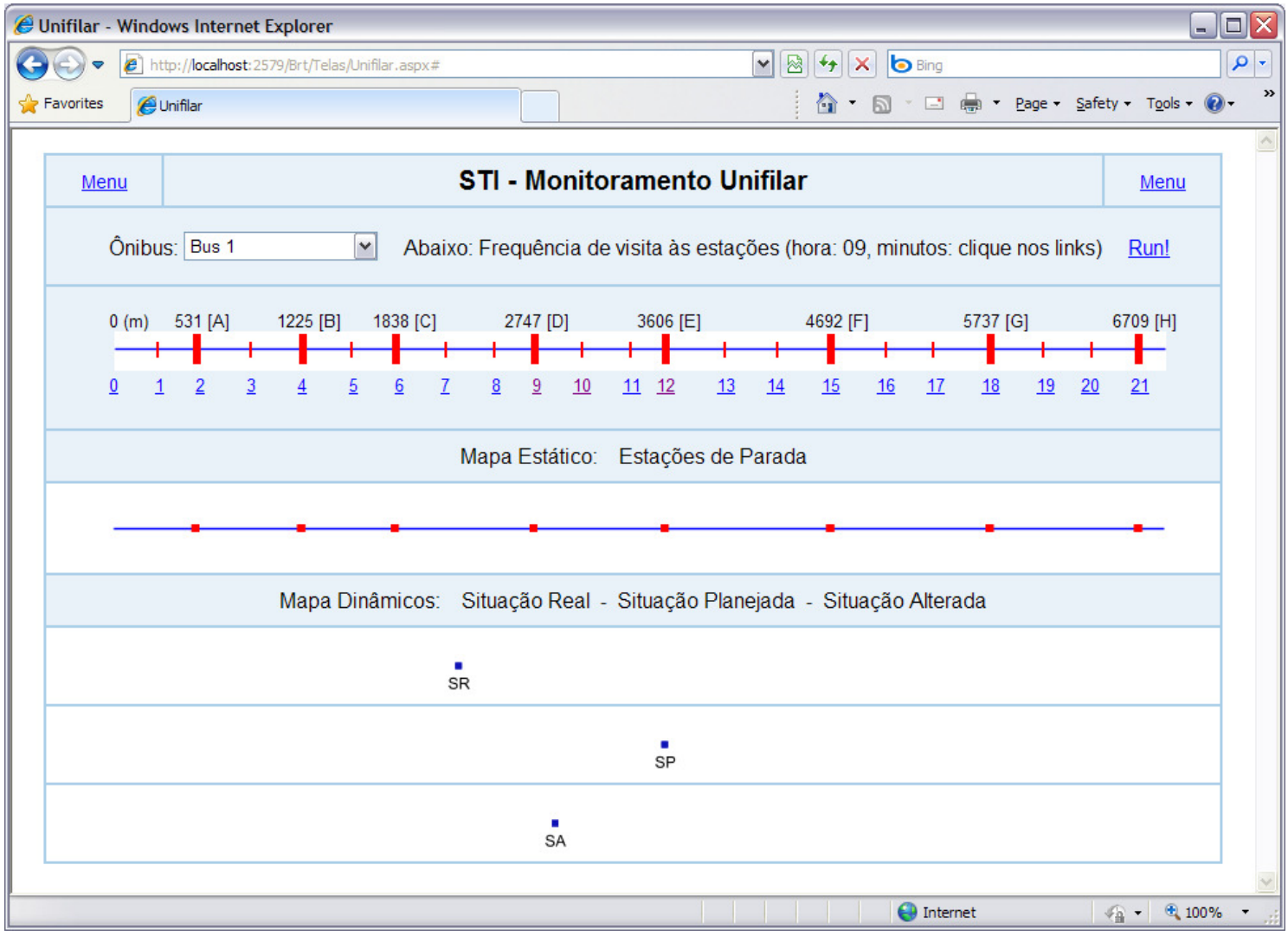

Figura 41 - Tela de acompanhamento e comparação das situações (SR, SP e SA)

O diagrama sem os minutos (trecho em azul com pontos em vermelho) ao centro da tela objetiva auxiliar na comparação dos três indicadores de situação dos ônibus (Situação Real [SR], Situação Planejada [SP] e Situação Alterada [SA]) que se encontram na parte inferior da tela (indicando onde está o ônibus em determinado minuto da simulação). Descrições das situações:

- SR: Indica a localização do ônibus na realidade. São as localizações georreferenciadas enviadas ao sistema baseado nos receptores GPS. Se essas localizações estiverem de acordo com o que sugere a grade-horária, o sistema nada tem a fazer.

- SP: Indica a localização onde o ônibus deveria estar num dado momento em situações normais, ou seja, é o que deveria ocorrer baseado nas grades de horário. 
- SA: Indica a localização do ônibus após o sistema intervir devido à inconformidade identificada (isto é, no caso de SR e SP divergirem).

Existem duas maneiras de ser feita a comparação visual nesta tela do sistema:

1. O usuário pode clicar sobre cada um dos 21 pontos de controle do primeiro diagrama unifilar da tela para observar os posicionamentos de SR, SP e SA.

2. O usuário pode clicar no link Run! que está no canto superior direito da tela de modo que as indicações de SR, SP e SA se moverão automaticamente ao longo dos 6883 metros do trecho.

No exemplo da Figura 41, no minuto 12, a SP era que o ônibus estivesse na estação $E$, mas ele está (SR) entre as estações $C$ e $D$ (pouco após o minuto 7), o que representa um atraso de aproximadamente 5 minutos. Neste contexto, o sistema identificou a inconformidade e realizou uma intervenção que resultou em melhora de aproximadamente 2 minutos neste dado momento (minuto 12) - ver a posição SA.

Durante o percurso do ônibus, como todas as estações monitoram suas próprias grades de horário, dependendo da tolerância de aceitação de inconformidade configurada no sistema, outras intervenções podem ser realizadas buscando sempre a conformidade em relação à grade-horária.

\subsection{Experimentações da metodologia}

Para a realização de simulações de comportamento (detecção de inconformidades e escolha de intervenções), os seguintes parâmetros, definições, e valores foram considerados:

- Velocidade média no corredor de ônibus: $25 \mathrm{~km} / \mathrm{h}$ (Brasil, 2007).

- Limite de velocidade no corredor de ônibus: $50 \mathrm{~km} / \mathrm{h}$ (dado obtido em trabalho de campo - este é o limite de velocidade no corredor. Data da aquisição do dado: 01/09/2010). 
- Tempo médio de embarque e desembarque nas estações e tempo morto: 40 segundos (Brasil, 2007).

- Espaçamento médio entre estações utilizadas na simulação: 900 metros (dado configurável no sistema e baseado em BRT's de baixa demanda, como o de Ottawa [Canadá], por exemplo).

- dt: tempo transcorrido (em minutos).

- dR: diferença de tempo (em minutos) entre a Situação Planejada (SP) e Situação Real (SR).

- dA: diferença de tempo (em minutos) entre a Situação Planejada (SP) e Situação Alterada (SA).

- st1 e st2: status (antes e depois do sistema ordenar alguma intervenção) em que o ônibus está: sob intervenção (B - busy) ou livre ( $F$ - free).

- ITV (intervalo de tempo para verificação da situação de cada estação): 2 min.

- ITPO (intervalo de tempo a se monitorar o próximo ônibus que deve chegar à estação): 5 min.

- VTAT (valor de tolerância antes de considerar o ônibus como ATRASADO): 5 $\min$.

- VTAD (valor de tolerância antes de considerar o ônibus como ADIANTADO): $1 \mathrm{~min}$.

- VLOE (valor limite para considerar intervenção ônibus extra): 15 min.

- Dados de grade-horária para um determinado serviço (também baseado em BRT's de baixa demanda).

Segundo o algoritmo e variáveis definidas para as simulações apresentadas a seguir, a cada 2 minutos (nos minutos pares) cada estação verifica quais ônibus deveriam chegar em menos de 5 minutos. É como se a estação "pensasse": "Nos próximos 5 minutos, quais ônibus deveriam chegar? Para cada um desses ônibus, eles estão atrasados mais que 5 minutos ou adiantados mais que 1 minuto se comparados com o horário que deveriam se apresentar? Se sim, qual intervenção pode ser realizada para melhorar a situação?'. 
Os valores das variáveis ITV, ITPO, VTAT, VTAD e VLOE, e os dados da gradehorária utilizados nas simulações não possuem fonte científica, foram apenas sugeridos pelo autor para fins de experimentação da metodologia sugerida neste trabalho.

As três simulações apresentadas a seguir são testes para verificar o comportamento dos algoritmos de identificação de inconformidade e seleção de intervenção. Para tanto, três diferentes problemas no percurso dos ônibus de um mesmo serviço cadastrado no sistema foram simulados:

1. Ônibus atrasado devido a sanfonamento na estação C.

2. Ônibus atrasado devido sanfonamento na estação $A$, tráfego intenso na região da estação e atraso inicial antes do início do trecho de análise.

3. Ônibus adiantado devido tráfego livre e motorista desatento.

Estes 3 problemas (inconformidades em relação a grade-horária previamente estabelecida) foram forçadamente introduzidos, alterando-se os dados da tabela que registra as posições instantâneas dos ônibus, para fins de experimentação da metodologia sugerida (não possuem base científica).

\subsubsection{Experimentação de Intervenção tipo Bypass (saltar estação)}

As ordens de bypass são enviadas somente nos casos em que o status (st1) esteja F (free). Após receber uma ordem de intervenção, o status (st2) passa a ser B (busy). Quando o ônibus passar pela estação de bypass, seu status volta a F (free).

Ocorrência: Ônibus atrasado devido sanfonamento na estação C.

A tabela a seguir apresenta as análises a cada dois minutos. A coluna Estação indica quais estações passam a monitorar o ônibus no tempo $d t$. 


\begin{tabular}{|c|c|c|c|c|c|c|}
\hline dt & Estação & $d R$ & $d A$ & st1 & Ação & st2 \\
\hline 2 & $B$ e $C$ & 0 & 0 & $\mathrm{~F}$ & $\begin{array}{l}\text { As estações B e C verificam que o } \\
\text { ônibus está dentro do tempo } \\
\text { planejado. }\end{array}$ & $F$ \\
\hline 4 & C e D & 0 & 0 & $\mathrm{~F}$ & $\begin{array}{l}\text { As estações C e D verificam que o } \\
\text { ônibus está dentro do tempo } \\
\text { planejado. }\end{array}$ & $\mathrm{F}$ \\
\hline 6 & D & 0,7 & 0,7 & $\mathrm{~F}$ & $\begin{array}{l}\text { A estação D considera que não há } \\
\text { inconformidade devido ao VTAT (5 } \\
\text { min.), mas visualmente já se observa } \\
\text { um pequeno atraso do ônibus em } \\
\text { relação à situação planejada } \\
\text { (aproximadamente } 0,7 \text { minutos). }\end{array}$ & $F$ \\
\hline 8 & $D$ e $E$ & 2 & 2 & $\mathrm{~F}$ & $\begin{array}{l}\text { A estação D ainda considera que o } \\
\text { ônibus está dentro do tempo } \\
\text { planejado devido ao VTAT ( } 5 \text { min.), } \\
\text { mas a estação E identifica que o } \\
\text { ônibus ultrapassou o limite do VTAT } \\
\text { (mas não em mais de } 15 \text { minutos) e } \\
\text { toma a decisão de que ele não pare } \\
\text { na próxima estação (bypass), que no } \\
\text { caso é a estação D. }\end{array}$ & B \\
\hline 10 & E e F & 4 & 4 & B & $\begin{array}{l}\text { As estações } \mathrm{E} \text { e } \mathrm{F} \text { identificam que } 0 \\
\text { ônibus ultrapassou o limite de } 5 \\
\text { minutos (mas não em mais de } 15 \\
\text { minutos), mas como o status está B, } \\
\text { não enviam ordem (o ônibus já está } \\
\text { com uma ordem a ser cumprida em } \\
\text { relação à estação D). }\end{array}$ & B \\
\hline 12 & $\mathrm{~F}$ & 4,7 & 2,6 & $\mathrm{~F}$ & $\begin{array}{l}\text { A estação F identifica que o ônibus } \\
\text { ultrapassou o limite de } 5 \text { minutos } \\
\text { (mas não em mais de } 15 \text { minutos) e }\end{array}$ & $\mathrm{F}$ \\
\hline
\end{tabular}




\begin{tabular}{|c|c|c|c|c|c|c|}
\hline & & & & & $\begin{array}{l}\text { poderia enviar uma ordem de bypass } \\
\text { pois o ônibus passou pela estação D } \\
\text { (seu status voltou a ser } F \text { ). Assim, o } \\
\text { sistema tenta executar um bypass (na } \\
\text { próxima estação [E]), mas não pode } \\
\text { ser executado (motivo: há solicitação } \\
\text { de parada para a estação } E \text { ). }\end{array}$ & \\
\hline 14 & $\mathrm{~F}$ e $\mathrm{G}$ & 4,3 & 1 & $F$ & $\begin{array}{l}\text { As estações } F \text { e } G \text { verificam que o } \\
\text { ônibus está dentro do tempo } \\
\text { planejado. }\end{array}$ & $F$ \\
\hline 16 & $\mathrm{GeH}$ & 4 & 1 & $F$ & $\begin{array}{l}\text { A estação G verifica que o ônibus } \\
\text { está dentro do tempo planejado, mas } \\
\text { a estação H identifica que o ônibus } \\
\text { ultrapassou o limite de } 5 \text { minutos e } \\
\text { toma a decisão para que ele não pare } \\
\text { na próxima estação (bypass), no } \\
\text { caso, a G. Mas novamente o bypass } \\
\text { não é executado por necessidade de } \\
\text { desembarcar passageiros. }\end{array}$ & $F$ \\
\hline 18 & $\mathrm{H}$ & 4 & 1 & $F$ & $\begin{array}{l}\text { A estação H verifica que o ônibus está } \\
\text { dentro do tempo planejado. }\end{array}$ & $F$ \\
\hline 20 & $\mathrm{H}$ & 4 & 1 & $F$ & $\begin{array}{l}\text { A estação H verifica que o ônibus está } \\
\text { dentro do tempo planejado. }\end{array}$ & $F$ \\
\hline
\end{tabular}

Tabela 3 - Análise dos 20 minutos da viagem para Saltar Estação

Tempos finais com e sem intervenção do sistema:

- Sem intervenção: 4 minutos de atraso.

- Após intervenção: 1 minuto de atraso.

A tela abaixo apresenta a situação no minuto 20. A SR está no minuto 16 e a SA no minuto 19 , o que mostra a diferença de 3 minutos, para melhor. 


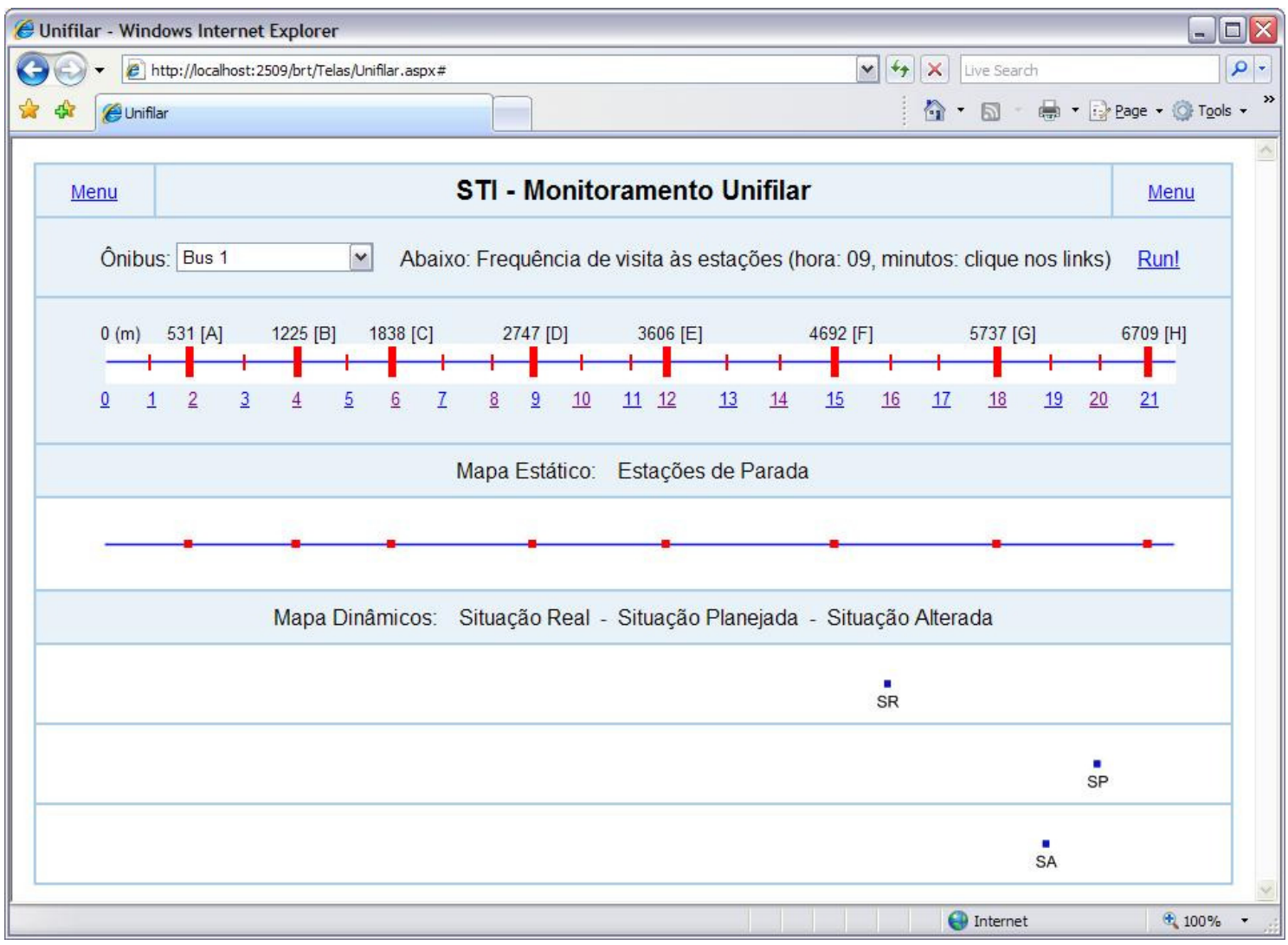

Figura 42 - Tela com as situações SR, SP e SA para intervenção Saltar Estação

Nesta simulação, por duas vezes (minutos 12 e 16) o sistema identifica uma inconformidade onde a intervenção Saltar Estação pode ser aplicada. Mas devido à necessidade de parada nas estações em questão, a intervenção não é aplicada. Mesmo assim, a melhoria da situação pode ser observada.

Segue abaixo os gráficos das três situações analisadas (SR, SP e SA) para esta simulação. A linha azul do gráfico é o tempo planejado (SP) conforme a grade de horários. Enquanto não há inconformidade, os três gráficos permanecem sobrepostos. A partir do momento que uma inconformidade de ônibus atrasado é identificada, o gráfico do atraso (cor rosa) passa a se distanciar do planejado (azul), pendendo para baixo, o que mostra que a metragem percorrida pelo ônibus está diminuindo em relação ao planejado. Quanto mais distante a linha rosa está da azul, maior a inconformidade. 


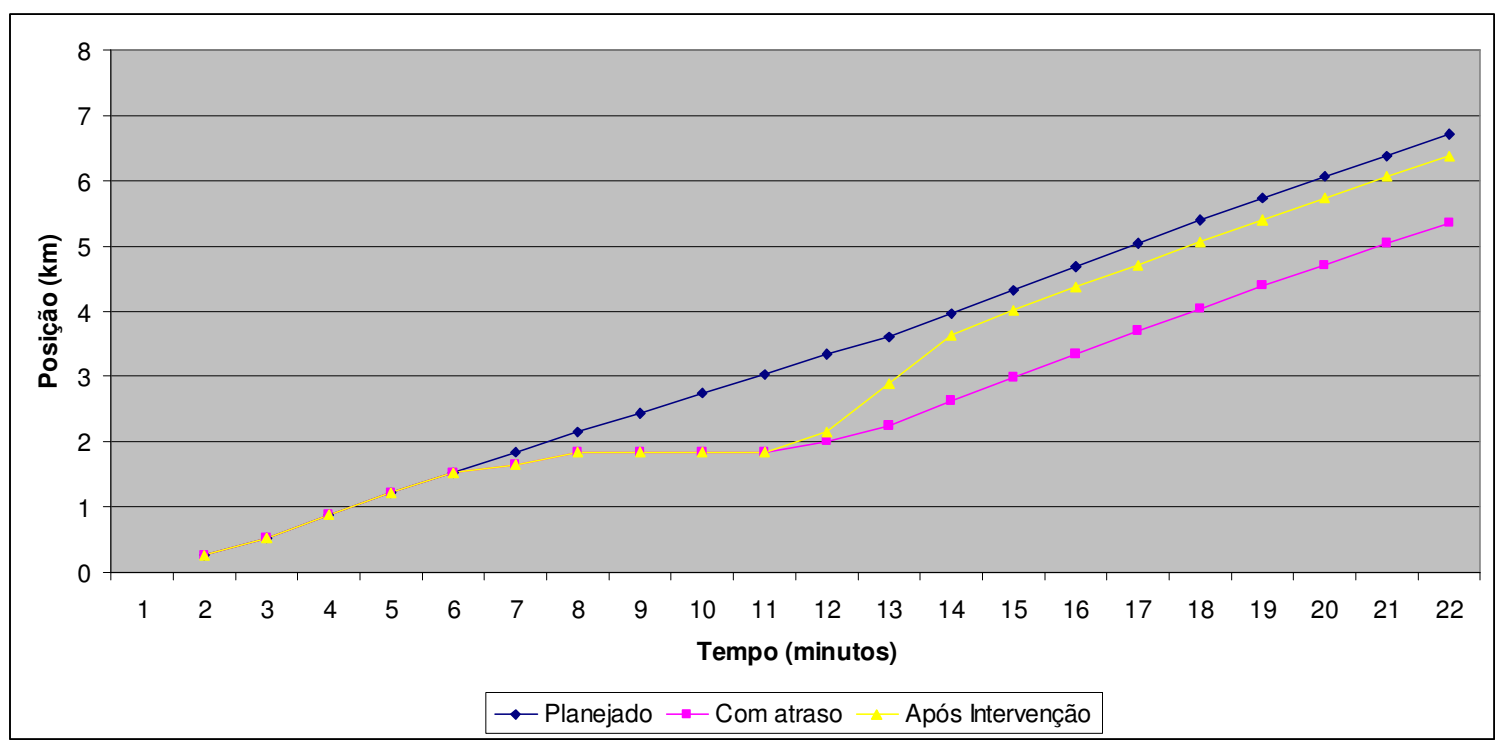

Gráfico 1 - Gráfico das situações SR, SP e SA para intervenção Saltar Estação

Análise do gráfico:

- Entre os minutos 6 e 11 o atraso vai crescendo conforme o tempo passa, e o gráfico de intervenção (amarelo) acompanha o gráfico de atraso pois a inconformidade ainda não foi considerada pelo sistema (devido à variável VTAT - tolerância).

- A partir do minuto 12 o gráfico amarelo (SA) inicia um afastamento do gráfico rosa (SR) se aproximando do gráfico azul (SP), o que indica a diminuição da inconformidade (a intervenção gerou o resultado esperado).

- Do minuto 14 até o final da simulação, a pequena inconformidade entre a situação planejada e real segue constante.

- E percebe-se também que a partir do minuto 11 o gráfico de atraso (SR) volta a subir, indicando que o ônibus saiu da situação de sanfonamento na estação C (o que causou a inconformidade). No entanto, o ônibus seguiu no seu serviço sem resolver a inconformidade.

Resultado do bypass: redução da inconformidade (diferença de tempo foi de 4 para 1 minuto de atraso) graças a:

1. Frenagem e re-aceleração do ônibus não necessárias na estação D; 
2. Tempo morto, embarque e desembarque não gasto na estação $D$;

3. Aumento de velocidade média no trecho também devido à utilização de segunda faixa de corredores, já que não se fez necessário esperar para acessar a estação.

\subsubsection{Experimentação de Intervenção tipo Ônibus Extra}

Se o atraso do ônibus ultrapassar 15 minutos, solicita-se outro ônibus.

Ocorrência: Sanfonamento na estação A, tráfego intenso na região da estação e atraso inicial antes do início do trecho de análise.

A tabela a seguir apresenta as análises a cada dois minutos. A coluna Estação indica quais estações passam a monitorar o ônibus no tempo $d t$.

\begin{tabular}{|l|l|l|l|l|l|l|}
\hline dt & Estação & dR & dA & st1 & Ação & st2 \\
\hline 2 & B e C & 2 & 2 & F & $\begin{array}{l}\text { A estação B verifica que o ônibus está } \\
\text { dentro do tempo planejado, mas a } \\
\text { estação C identifica que o ônibus } \\
\text { ultrapassou o limite de 5 minutos } \\
\text { (mas não em mais de 15 minutos) e } \\
\text { toma a decisão para que ele não pare } \\
\text { na próxima estação (bypass na A). }\end{array}$ & B \\
\hline 4 & C e D & 3,5 & 3,5 & B & $\begin{array}{l}\text { As estações C D identificam que o } \\
\text { ônibus ultrapassou o limite de 5 } \\
\text { minutos (mas não em mais de 15 } \\
\text { minutos). Mas não solicitam bypass } \\
\text { porque o ônibus já se encontra sob } \\
\text { comando de intervenção (o ônibus } \\
\text { está com uma ordem a ser cumprida } \\
\text { em relação à estação A). }\end{array}$ & B \\
\hline
\end{tabular}




\begin{tabular}{|c|c|c|c|c|c|c|}
\hline 6 & $D$ & 5 & 5 & B & $\begin{array}{l}\text { Novamente a estação D identifica que } \\
\text { o ônibus ultrapassou o limite de } 5 \\
\text { minutos (não em mais de } 15 \text { minutos). } \\
\text { Mas não solicita bypass porque o } \\
\text { ônibus já se encontra sob comando } \\
\text { de intervenção (bypass na estação A). }\end{array}$ & B \\
\hline 8 & De $E$ & 6 & 6 & B & $\begin{array}{l}\text { As estações D e E identificam que o } \\
\text { ônibus ultrapassou o limite de } 5 \\
\text { minutos (mas não em mais de } 15 \\
\text { minutos). Mas não solicitam bypass } \\
\text { porque o ônibus já se encontra sob } \\
\text { comando de intervenção (bypass na } \\
\text { estação A). }\end{array}$ & B \\
\hline 10 & E e F & 8 & 8 & B & $\begin{array}{l}\text { As estações E e F identificam que o } \\
\text { ônibus ultrapassou o limite de } 5 \\
\text { minutos (mas não em mais de } 15 \\
\text { minutos). Mas não solicitam bypass } \\
\text { porque o ônibus já se encontra sob } \\
\text { comando de intervenção (bypass na } \\
\text { estação A). }\end{array}$ & B \\
\hline 12 & $\mathrm{~F}$ & 10 & 10 & B & $\begin{array}{l}\text { A estação } F \text { identifica que o ônibus } \\
\text { ultrapassou o limite de } 5 \text { minutos } \\
\text { (mas não em mais de } 15 \text { minutos). } \\
\text { Mas não solicita bypass porque o } \\
\text { ônibus já se encontra sob comando } \\
\text { de intervenção (bypass na estação A). }\end{array}$ & B \\
\hline 14 & $\mathrm{~F}$ e $\mathrm{G}$ & 11,6 & 11,6 & $\mathrm{~F}$ & $\begin{array}{l}\text { As estações } F \text { e G identificam que o } \\
\text { ônibus ultrapassou o limite de } 5 \\
\text { minutos (mas não em mais de } 15 \\
\text { minutos). Ambas as estações tomam } \\
\text { a decisão para que o ônibus não pare } \\
\text { na próxima estação (bypass), no } \\
\text { caso, a B. Mas o ônibus não }\end{array}$ & B \\
\hline
\end{tabular}






Tabela 4 - Análise dos 20 minutos da viagem para Ônibus Extra

Tempos finais com e sem intervenção do sistema:

- Sem intervenção: 16,3 minutos de atraso.

- Após intervenção: 3 minutos de atraso. 
A tela abaixo apresenta a situação no minuto 20. A SR ainda está no minuto 3,7 e a SA no minuto 17, o que mostra a diferença de 13,3 minutos, para melhor. Observase ainda uma segunda ocorrência de SA no minuto 4. Isso se deve ao fato de existir no minuto 20, um ônibus a mais em operação para o serviço monitorado.

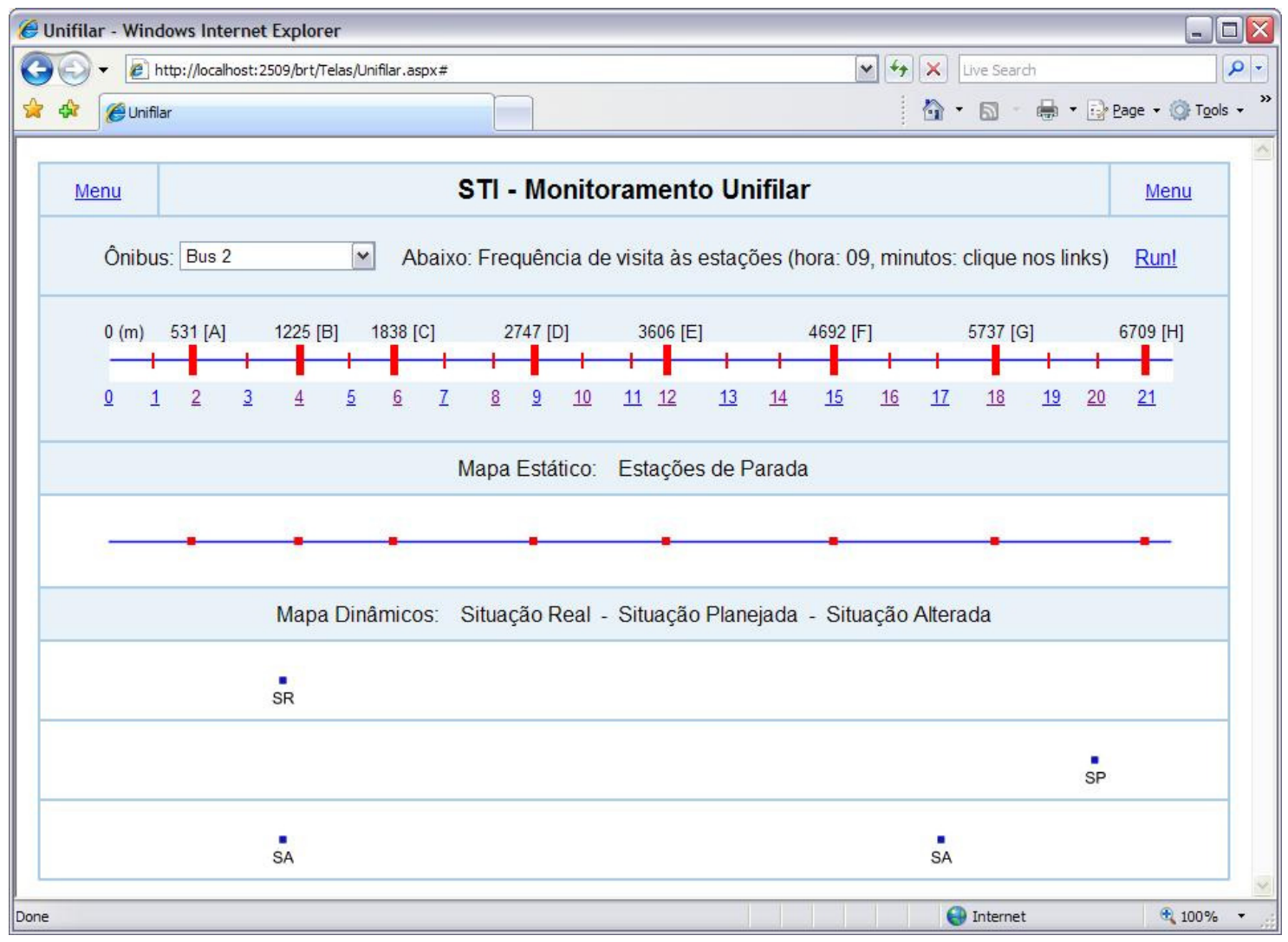

Figura 43 - Tela com as situações SR, SP e SA para intervenção Ônibus Extra

Segue abaixo os gráficos das três situações analisadas (SR, SP e SA) para esta simulação. Desde o início já se identifica separação dos gráficos azul e rosa, indicando inconformidade. E por muito tempo os gráficos SR e SA estão sobrepostos, indicando que a inconformidade não está sendo corrigida. Até que subitamente o gráfico amarelo (SA) sofre um salto diminuindo consideravelmente a inconformidade (justamente quando o ônibus extra entra em operação no serviço). 


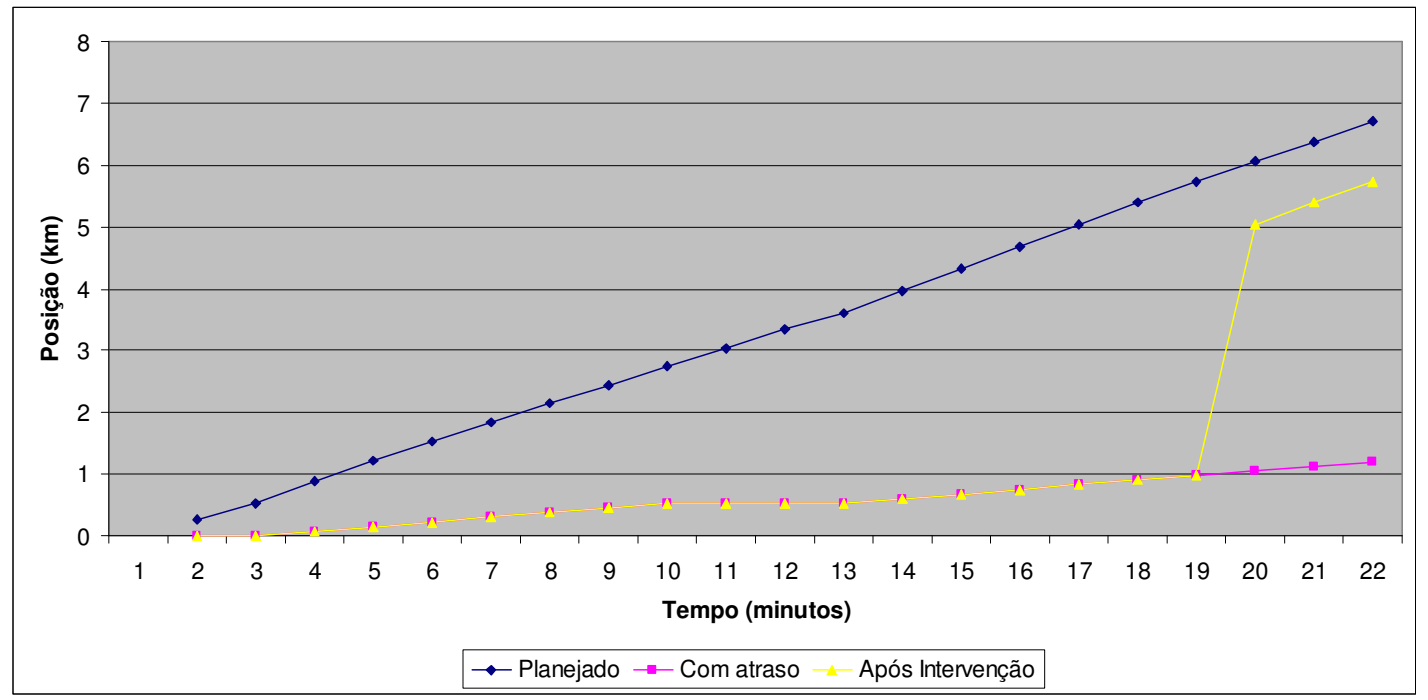

Gráfico 2 - Gráfico das situações SR, SP e SA para intervenção Ônibus Extra

Análise do gráfico:

- Entre os minutos 2 e 19 a inconformidade só aumentou.

- Entre os minutos 19 e 20 o ônibus extra entrou em serviço e o gráfico SA distanciou-se rapidamente do SR, o que é uma diminuição significativa na inconformidade.

- Do minuto 20 até o final da simulação a inconformidade entre a situação planejada e real seguiu constante (e aceitável, devido VTAT - tolerância).

\subsubsection{Experimentação de Intervenção para Ônibus Adiantado}

Ocorrência: Tráfego livre faz com que o motorista se adiante em relação à gradehorária. A tabela a seguir apresenta as análises a cada dois minutos:

\begin{tabular}{|l|l|l|l|l|l|l|}
\hline dt & Estação & dR & dA & st1 & \multicolumn{1}{|c|}{ Ação } & st2 \\
\hline 2 & B e C & 0 & 0 & F & $\begin{array}{l}\text { As estações B e C verificam que o } \\
\text { ônibus está dentro do tempo } \\
\text { planejado. }\end{array}$ & F \\
\hline 4 & C e D & 0 & 0 & F & As estações C e D verificam que o & F \\
\hline
\end{tabular}




\begin{tabular}{|c|c|c|c|c|c|}
\hline & & & & & $\begin{array}{l}\text { ônibus está dentro do tempo } \\
\text { planejado. }\end{array}$ \\
\hline 6 & $D$ & 0 & 0 & $F$ & $\begin{array}{l}\text { A estação D verifica que o ônibus está } \\
\text { dentro do tempo planejado. }\end{array}$ \\
\hline 8 & $E$ & 1,4 & 1,4 & $F$ & $\begin{array}{l}\text { A estação } E \text { identifica que o ônibus } \\
\text { está adiantado mais do que o valor de } \\
\text { tolerância de } 1 \text { minuto (VTAD) e ainda } \\
\text { distante o suficiente da próxima } \\
\text { estação. Assim, decide pela } \\
\text { intervenção diminuir a velocidade. }\end{array}$ \\
\hline 10 & $F$ & 1 & 1 & $B$ & $\begin{array}{l}\text { A estação F identifica que o ônibus } \\
\text { está adiantado } 1 \text { minuto (novamente } \\
\text { maior que VTAD), mas como o ônibus } \\
\text { já está sob intervenção (status B), não } \\
\text { envia ordem. }\end{array}$ \\
\hline 12 & $F$ & 0,5 & 0,5 & $F$ & $\begin{array}{l}\text { A estação } F \text { identifica que o ônibus } \\
\text { está adiantado } 0,4 \text { minutos (menos } \\
\text { que VTAD). Como o tempo é inferior à } \\
\text { tolerância, não envia ordem. }\end{array}$ \\
\hline 14 & $\mathrm{~F}$ e $\mathrm{G}$ & 0,4 & 0,4 & $F$ & $\begin{array}{l}\text { As estações } \mathrm{F} \text { e } \mathrm{G} \text { identificam que o } \\
\text { ônibus está adiantado } 0,4 \text { minutos. } \\
\text { Como o tempo é inferior à tolerância, } \\
\text { não enviam ordem. }\end{array}$ \\
\hline 16 & $\mathrm{GeH}$ & 0,4 & 0,4 & $F$ & $\begin{array}{l}\text { As estações } \mathrm{G} \text { e } \mathrm{H} \text { identificam que } 0 \\
\text { ônibus continua adiantado } 0,4 \\
\text { minutos e não enviam ordem. }\end{array}$ \\
\hline $\begin{array}{l}18 \\
e \\
20\end{array}$ & $\mathrm{H}$ & 0,4 & 0,4 & $F$ & $\begin{array}{l}\text { Nos minutos } 18 \text { e } 20 \text { a estação H } \\
\text { identifica que o ônibus está adiantado } \\
0,4 \text { minutos e não envia ordem devido } \\
\text { o valor ser menor que a tolerância. }\end{array}$ \\
\hline
\end{tabular}

Tabela 5 - Análise dos 20 minutos da viagem para Ônibus Adiantado 
Tempos finais com e sem intervenção do sistema no minuto 16:

- Sem intervenção: 5,5 minutos adiantado.

- Após intervenção: 0,4 minutos adiantado.

A tela abaixo apresenta a situação no minuto 16. A SR está no minuto 21,5 e a SA no minuto 16,4 , o que mostra a diferença de 5,1 minutos, para melhor.



Figura 44 - Tela com as situações SR, SP e SA para intervenção Ônibus Adiantado

Segue abaixo os gráficos das três situações analisadas (SR, SP e SA) para esta simulação. Igualmente aos dois casos de inconformidade anteriormente apresentados, conforme os gráficos SR e SP se distanciam, está caracterizada a inconformidade. Porém, como esta simulação trata-se de um ônibus adiantado (diferentemente aos dois casos antes apresentados onde os ônibus estavam atrasados), o gráfico da situação real (SR) pende para cima em relação ao gráfico da situação planejada (SP). 


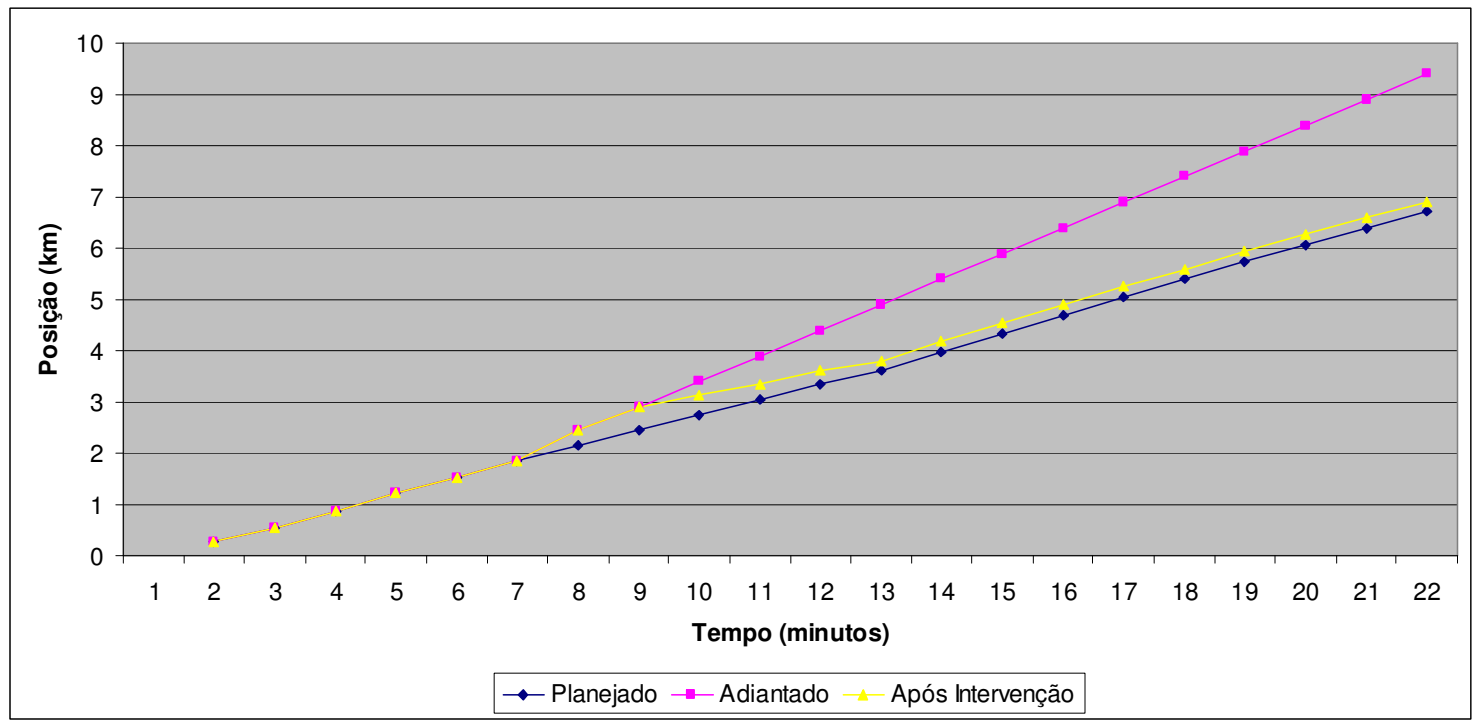

Gráfico 3 - Gráfico das situações SR, SP e SA para intervenção Ônibus Adiantado

Análise do gráfico:

- Entre os minutos 7 e 9 o ônibus segue adiantado sem interferência do sistema.

- A partir do minuto 9 até o 13, nota-se que o gráfico amarelo (SA) inicia um afastamento do gráfico rosa (SR) se aproximando do gráfico azul (SP), o que indica a diminuição da inconformidade.

- Do minuto 14 até o final da simulação, a pequena inconformidade entre a situação planejada e real segue constante. 


\section{CONCLUSÕES E CONTINUIDADE DO TRABALHO}

Analisando os gráficos apresentados anteriormente no Capítulo 8 (simulações) com as três situações (Real, Planejada e Alterada) dos ônibus, fica claro que as intervenções realizadas diminuíram consideravelmente as defasagens de tempo dos ônibus em relação às grades de horário, o que torna a metodologia adotada uma abordagem viável na melhoria da adequação do fluxo dos ônibus em relação aos seus compromissos. $E$ isso tem como conseqüência a melhoria na qualidade do serviço e diminuição do sanfonamento nas estações em sistemas BRT de baixa demanda de passageiros, já que em sistemas BRT como o de Bogotá (alta demanda), testes mais exaustivos da metodologia proposta deveriam ser aplicados para comprovar sua eficácia

Uma das escolhas feitas durante a pesquisa foi a de cada estação se responsabilizar em monitorar os ônibus que a envolvem diretamente em uma determinada "janela" de tempo. Essa escolha dirigiu o trabalho de forma a propor cada estação identificar e intervir em suas respectivas áreas. Mas como essas áreas têm forte interação, um benefício geral pode ser observado. Concluiu-se que as intervenções pontuais (baseadas em estações) afetam o serviço como um todo, isto é, afetam o comportamento geral do serviço ao longo da rota.

Com base na utilização de monitoramento de frotas e sistema de informação geográfica, é possível modelar (e implementar) um sistema que identifique inconformidades e realize intervenções nos serviços de transporte urbano, melhorando assim a qualidade do serviço do transporte público. Esta pequena contribuição em forma de dissertação confirma mais uma vez o que se encontra na literatura a respeito de: (1) vantagens na utilização do monitoramento de frota em diversas áreas de transportes; (2) benefícios e aplicabilidade que os sistemas de informação geográfica propiciam.

O modelo de solução proposto neste trabalho tem como base principal a sua aplicabilidade em corredores segregados para trânsito de ônibus, preferencialmente com faixas duplas de rodagem em toda extensão do corredor, e controle tarifário em 
sua grande parte externamente ao veículo. Essas são características fundamentais dos sistemas BRT para o bom fluxo do sistema de transporte. A pesquisa em relação ao BRT é repleta de novas descobertas no que diz respeito ao sistema de transporte público urbano. Até mesmo reflexões mais filosóficas como a respeito de que direção a humanidade seguiu enquanto as cidades cresciam, na qual se esqueceu completamente que as ruas devem ser muito mais para as pessoas do que para os carros (e obviamente também para os meios de transporte coletivo). $O$ Manual de BRT oferece um nível técnico bem aprofundado para planejamento e implantação do sistema de transporte, mas também fornece uma base para entendermos que as cidades seriam bem melhores seguindo o estilo proposto já pela capa do livro (apresentado na Figura 4), onde um grande número de pessoas, ônibus, bicicletas e comércios parecem estar em plena harmonia em um grande centro urbano.

Como continuidade do presente trabalho, os seguintes itens o enriqueceriam se investigados:

1. Alterações de tempos de semáforos: solicita-se ao sistema de semáforos que diminua ou aumente o tempo do vermelho e verde dos semáforos, de modo que o ônibus se adiante ou atrase. Existem diversos modelos de controle semafórico (como descrito previamente no Capítulo 1), e a integração de um deles com o controle proposto neste trabalho pode trazer bons resultados.

2. A estratégia básica do trabalho apresentado é o monitoramento por parte das estações dos próximos ônibus que deveriam atendê-las. Um comportamento adicional por parte da estação poderia ser: ela monitorar seu próprio estado e tomar decisões com base nele. Exemplo: se uma determinada estação vê-se em situação de sanfonamento, pode analisar os ônibus que causam a fila, bem como os ônibus que estão próximos, para solicitar bypass de ônibus, diminuindo o sanfonamento. 
3. Em termos do funcionamento apresentado neste trabalho, o próximo passo seria das simulações serem realizadas com um número maior de ônibus do mesmo serviço (e ônibus de outros serviços também), para se obter resultados mais reais e efetivos da dinâmica do tráfego dos ônibus e das intervenções. Se possível, dados reais de serviços e de grades horárias poderiam ser adquiridos para tornar a experimentação ainda mais próxima do real.

4. Pelo fato de cada estação "se monitorar", pode ocorrer o fato de duas estações identificarem inconformidade em um mesmo ônibus, e ambas selecionarem uma intervenção para ele. Como as intervenções selecionadas podem não ser as mesmas, haveria um conflito de ordens. Por isso, uma segunda análise deveria ser realizada para decidir qual intervenção seria acatada, caso duas ou mais sejam ordenadas. 


\section{REFERÊNCIAS BIBLIOGRÁFICAS}

BRASIL. Ministério das Cidades. Manual de BRT (bus rapid transit): guia de planejamento. Autores colaboradores: César Arias [et al]. Tradução de Arthur Szasz. New York: Institute for Transportation \& Development Policy; Brasília: Ministério das Cidades, 2007. 898 p.

CÂMARA, G. et al. Anatomia de sistemas de informações geográficas. Campinas: UNICAMP, 1996.

CARRARA, C. M. Uma aplicação do SIG para a localização e alocação de terminais logísticos em áreas urbanas congestionadas. 2008. 246 p. Dissertação (Mestrado) - Escola de Engenharia de São Carlos, Universidade de São Paulo, São Carlos, 2007.

CARVALHO, J. D. Definição do modal de transporte ótimo para componentes comprados numa empresa aeronáutica brasileira. 2006. 126 p. Dissertação (Mestrado) - Escola Politécnica, Universidade de São Paulo, São Paulo, 2006.

CASTRO, C. F. C. Avaliação de fatores intervenientes nas emissões veiculares em corredores de ônibus. 2008. 164 p. Dissertação (Mestrado) Escola Politécnica, Universidade de São Paulo, São Paulo, 2008.

CHITNIS, M.; TIWARI, P.; ANANTHAMURTHY, L. Sequence diagram in UML. Developer.com, 2003. Disponível em: $<$ http://www.developer.com/design/article.php/3080941/Sequence-Diagram-inUML.htm>. Acesso em: 10 maio 2009.

CUNHA, J. N. Metodologia de geração dinâmica de padrões de viagens rodoviárias para monitoramentos inteligentes de veículos de carga em sistemas AVL. 2008. 151 p. Dissertação (Mestrado) - Escola Politécnica, Universidade de São Paulo, São Paulo, 2008.

DELGADO, F.; MUÑOZ, J. C.; GIESEN, R.; CIPRIANO, A. Real-Time Control of Buses in a Transit Corridor Based on Vehicle Holding and Boarding Limits. Transportation Research Record: Journal of the Transportation Research Board - DOI: 10.3141/2090-07 - Pages 59-67, 2009. 
DIAS, R. A. Emprego de sistemas de informação geográfica (SIG) no controle da raiva canina. 2001. 97 p. Dissertação (Mestrado) - Faculdade de Medicina Veterinária e Zootecnia - Universidade de São Paulo, São Paulo, 2001.

DIAZ, R. B.; HINEBAUGH, D. Characteristics of BUS RAPID TRANSIT for Decision-Making. U.S. Department of Transportation - Project No. FTA-FL-267109.2009.1 - 2009. Disponível em: <http://www.nbrti.org/docs/pdf/2009_CBRT _combined.pdf>. Acesso em: 04 dez. 2010.

EMPRESA1. Empresa especializada em transporte público coletivo. Disponível em: <http://www.empresa1.com.br/>. Acesso em: 29 nov. 2010.

FILETO, R. O modelo entidade-relacionamento. São Carlos: Universidade Federal de São Carlos, 2010. 48 p. Apresentação para disciplina de graduação do Departamento de Informática e Estatística, INE-5423 - Banco de Dados I. Disponível em: <http://www.inf.ufsc.br/ fileto/Disciplinas/INE5423-20101/Aulas/02-MER.pdf>. Acesso em: 25 abr. 2010.

GARCIA, T. R.; CURY, J. R.; KRAUS JR, W. Modelagem e Projeto de Coordenação Semafórica Através da Álgebra MAX-PLUS. XX ANPET Congresso de Pesquisa e Ensino em Transportes, 2006, Brasília.

GEOSERVER. Site de internet oficial do servidor de mapas GeoServer. Disponível em: <http://geoserver.org/display/GEOS/What+is+Geoserver>. Acesso em: 14 set. 2009.

GOULD, M.; GRANELL, C. Avances en las infraestructuras de datos espaciales. Castelló de la plana: Universitat Jaume I, 2006. Treballs d’Informàtica i Tecnología - Número 26.

HOFFMAN, A. Advanced Network Planning for Bus Rapid Transit: The "Quickway Model" as a Modal Alternative to "Light Rail Lite". U.S. Department of Transportation - Report No. FL-26-7104-4 - 2008. Disponível em: <http://www.nbrti.org/docs/pdf/BRT\%20Network\%20Planning\%20Study\%20\%20Final\%20Report.pdf>. Acesso em: 04 dez. 2010.

KOEHLER, L. A.; KRAUS JR, W. Sistema de Prioridade para Ônibus com Controle da Partida do Ponto. XX ANPET - Congresso de Pesquisa e Ensino em Transportes, 2006, Brasília. 
KOEHLER, L. A.; KRAUS JR, W; CAMPONOGARA, E. Controle Integrado de Prioridade e Retenção para um Sistema BRT. XXII ANPET - Congresso de Pesquisa e Ensino em Transportes, 2008, Fortaleza.

LADEIRA, M. C.; MICHEL, F. D.; PAVANATTO, S. A. Monitoramento para Operação de Transporte Público: O Caso de Porto Alegre. XXIII ANPET Congresso de Pesquisa e Ensino em Transportes, 2009, Vitória.

LINDAU, L. A.; HIDALGO, D.; FACCHINI, D. Curitiba, the Cradle of Bus Rapid Transit. Built Environment - Volume: 36 | Issue: 3 | Pages: 274 - 282, 2010.

LINDAU, L. A.; SENNA, L. A. S.; STRAMBI, O.; MARTINS, W. C.; Alternative financing for Bus Rapid Transit (BRT): The case of Porto Alegre, Brazil. Research in Transportation Economics 22 (2008) 54-60, 2008.

M2M. Empresa especializada em soluções para gestão de frota de ônibus. Disponível em: <http://www.m2msolutions.com.br/>. Acesso em: 29 nov. 2010.

MIT News. Site de notícias do Massachusetts Institute of Technology. Disponível em: <http://web.mit.edu/newsoffice/2010/rapid-transit-grant.html>. Acesso em: 02 dez. 2010.

MACORATTI, J. C. Modelando sistemas em UML: casos de uso. Macoratti.net, fev. 2004. Disponível em: <http://www.macoratti.net/net_uml2.htm>. Acesso em: 12 dez. 2007.

MARQUES, H. N. Um sistema de informações para usuários de transporte coletivo em cidades de médio porte. 1998. 106 p. Dissertação (Mestrado) Escola de Engenharia de São Carlos, Universidade de São Paulo, São Carlos, 1998.

NOGUEIRA, A. UML - unified modeling language: casos de uso. Linhadecodigo.com, set. 2005. Disponível em: $<$ http://www.linhadecodigo.com.br/Artigo.aspx?id=802>. Acesso em: 10 jan. 2009.

NOGUEIRA, A. UML - unified modeling language: introdução e histórico. Linhadecodigo.com, jul. 2005. Disponível em: $<\mathrm{http}: / /$ www.linhadecodigo.com.br/Artigo.aspx?id=763>. Acesso em: 11 jan. 2009. 
OGC. Open Geospatial Consortium, Inc.®. Disponível em:

<http://www.opengeospatial.org/>. Acesso em: 11 jun. 2010.

OLIVEIRA, S. P. Implementação de roteirização para malha rodoviária do estado de Minas Gerais. 2000. 39 p. Monografia (Especialização em Geoprocessamento) - Centro de Sensoriamento Remoto, Universidade Federal de Minas Gerais, Belo Horizonte, 2000.

ORDÓÑEZ, C.; MARTÍNEZ, A. Sistemas de información geográfica: aplicaciones prácticas con IDRISI32 al análisis de riesgos naturales y problemáticas medioambientales. Madrid: Ra-Ma, 2003. 227 p.

PCMAG. Revista especializada em informática que possui uma enciclopédia digital de termos de informática. Disponível em:

<http://www.pcmag.com/encyclopedia_term/0,2542,t\%253DIDE\%2526i\%253D4 4707,00.asp >. Acesso em: 05 jun. 2009.

PEÑALOSA, E. Transporte para cidades melhores. São Paulo, Escola Politécnica da Universidade de São Paulo, 30 nov. 2009. Seminário organizado pela EPUSP e ITDP, São Paulo, 2009.

RAIA JUNIOR, A. A. Acessibilidade e mobilidade na estimativa de um índice de potencial de viagens utilizando redes neurais artificiais e sistemas de informações geográficas. 2001.212 p. Tese (Doutorado) Escola de Engenharia de São Carlos, Universidade de São Paulo, São Carlos, 2000.

REGIS, J.; HERMOSILLA, L. Sistema de monitoramento do transporte via GPS: estudo de caso. Revista Científica Eletrônica de Sistemas de Informação, Ano IV, Número 06, fev. 2007. Disponível em: <http://www.revista.inf.br/sistemas06/artigos/edic6anolVfev2007-artigo05.pdf>. Acesso em: 13 jun. 2010.

REIS, J. V. A. Heurísticas baseadas em busca de vizinhança variável para o problema de programação integrada de veículos e tripulações no transporte coletivo urbano por ônibus. 2008. 119 p. Dissertação (Mestrado) Escola Politécnica, Universidade de São Paulo, São Paulo, 2008.

SANTOS, L.; FERREIRA, D. L. Sistema de informação geográfica aplicado ao planejamento de trânsito e transportes. Caminhos de Geografia, Uberlândia, 5(12)94-113, jun. 2004. Disponível em: 
$<$ http://www.caminhosdegeografia.ig.ufu.br/include/getdoc.php?id=591\&article= 102\&mode=pdf $>$. Acesso em: 01 maio 2010.

SCHRAMM, L.; WATKINS, K.; RUTHERFORD, S. Features That Affect Variability of Travel Time on Bus Rapid Transit Systems. Transportation Research Record: Journal of the Transportation Research Board - Issue Number: 2143 - 186p. - 2010.

SILVA, A. N. R. Sistemas de informações geográficas para planejamento de transportes. 1998. 124 p. Tese (Livre-Docência) - Escola de Engenharia de São Carlos, Universidade de São Paulo, São Carlos, 1998.

TACOM. Empresa especializada em transporte público coletivo. Disponível em: <http://www.tacom.com.br/>. Acesso em: 29 nov. 2010.

TEIXEIRA, A. L. A.; CHRISTOFOLETTI, A. Sistemas de informação geográfica: dicionário ilustrado. São Paulo: Hucitec. 1997. 244 p.

TIAGO, H. C. Introdução a modelagem utilizando UML. Linhadecodigo.com, fev. 2010. Disponível em: <http://www.linhadecodigo.com.br/Artigo.aspx?id= 2801>. Acesso em: 17 mar. 2010.

W3SCHOOLS. Site de internet especializado em informática e linguagens de programação. Disponível em: <http://www.w3schools.com/web/web_sql.asp>. Acesso em: 05 jun. 2009.

WRIGHT, L. Bus Rapid Transit: A Public Transport Renaissance. Built Environment - Volume: 36 | Issue: 3 | Pages: 269 - 273, 2010. 